\title{
INL Seismic Monitoring Annual Report: \\ January 1, 2012 - December 31, 2012
}

S. J. Payne, D. F. Bruhn, J. M. Hodges, and R. G. Berg

December 2014

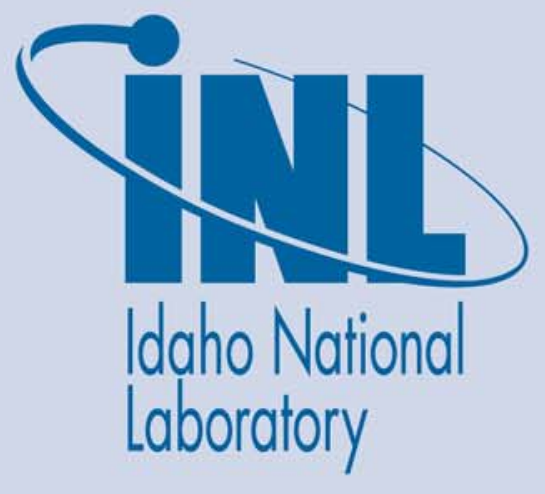

The INL is a U.S. Department of Energy National Laboratory operated by Battelle Energy Alliance 


\title{
INL Seismic Monitoring Annual Report: January 1, 2012 - December 31, 2012
}

\author{
S. J. Payne, D. F. Bruhn , J. M. Hodges, and R. G. Berg
}

December 2014

\author{
Idaho National Laboratory \\ Nuclear Safety and Engineering Programs/ \\ Engineering Technical Authority \\ Idaho Falls, Idaho 83415
}

Prepared for the U.S. Department of Energy Office of Nuclear Energy, Science, and Technology Under DOE Idaho Operations Office

Contract DE-AC07-05ID14517 
(Intentionally Blank) 


\section{SUMMARY}

During 2012, the Idaho National Laboratory Seismic Monitoring Program evaluated 17,329 independent triggers that included earthquakes from around the world, the western United States, and local region of the Snake River Plain. Seismologists located 1,460 earthquakes and man-made blasts within and near the $161-\mathrm{km}$ (or 100-mile) radius of the Idaho National Laboratory. Of these earthquakes, 16 had small-to-moderate size magnitudes (M) from 3.0 to 3.6. Within the $161-\mathrm{km}$ radius, the majority of 695 earthquakes $(\mathrm{M}<3.6)$ occurred in the active regions of the Basin and Range Provinces adjacent to the eastern Snake River Plain. Only 11 microearthquakes occurred within the Snake River Plain, four of which occurred in Craters of the Moon National Monument and Preserve. The earthquakes had magnitudes from 1.0 to 1.7 and occurred at deep depths (11$24 \mathrm{~km}$ ). Two events with magnitudes less than 1.0 occurred within the Idaho National Laboratory boundaries and had depths less than $10 \mathrm{~km}$. 
(Intentionally Blank) 


\section{ACKNOWLEDGEMENTS}

We thank Seth Carpenter (now at the University of Kentucky) for his assistance performing earthquake analysis during 2012. We also thank staff at the University of Utah Seismograph Stations, U. S. Geological Survey, and Montana Bureau of Mines and Geology for their earthworm data shares. We also appreciate the support of Incorporated Research Institutions in Seismology (IRIS). The research was funded by the Idaho National Laboratory through the U.S. Department of Energy Idaho Operations Office contract DE-AC0705 ID 14517. 
(Intentionally Blank) 


\section{CONTENTS}

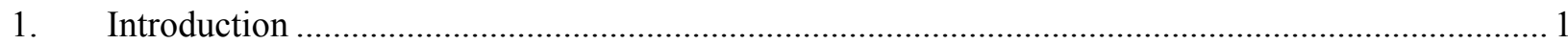

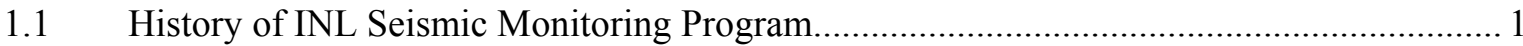

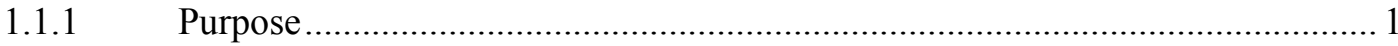

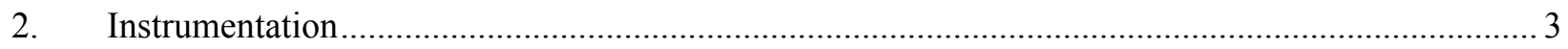

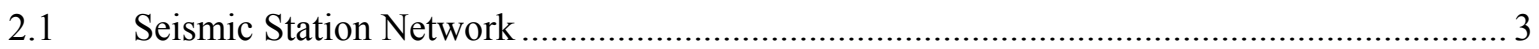

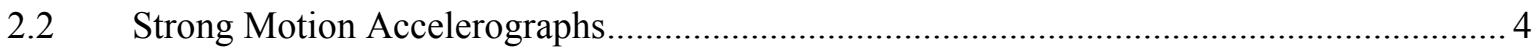

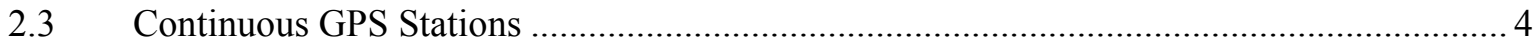

2.4 Seismic Data Acquisition and Analysis System.......................................................... 5

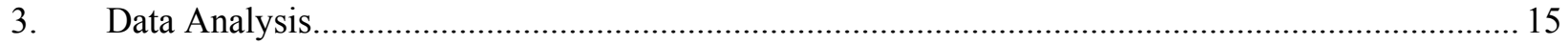

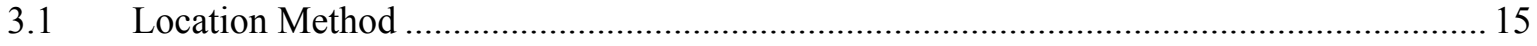

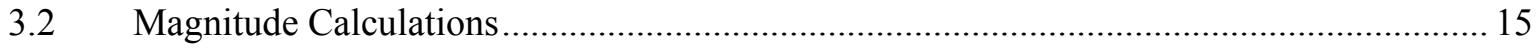

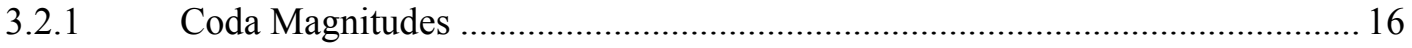

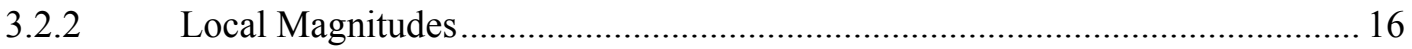

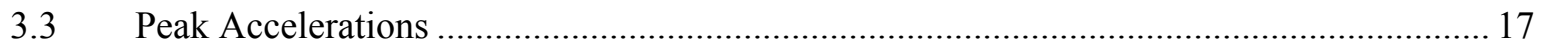

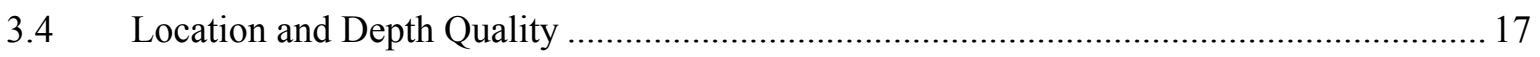

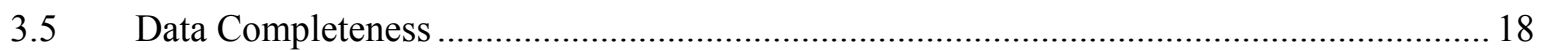

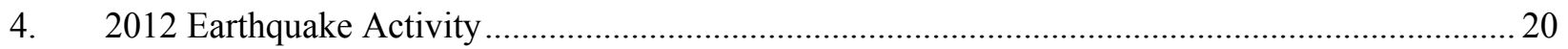

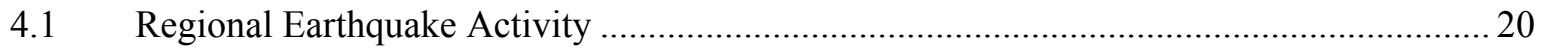

4.2 Earthquake Activity within 161-km Radius of INL .................................................. 20

4.3 Earthquakes within the Eastern Snake River Plain ....................................................... 21

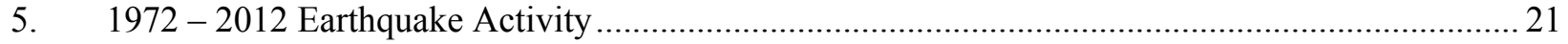

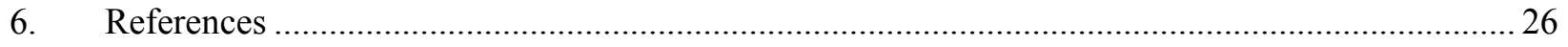

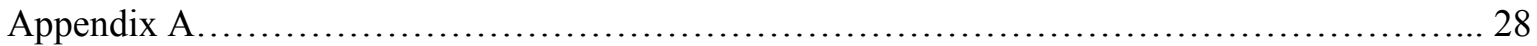




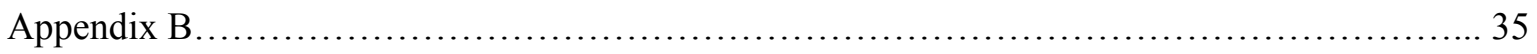

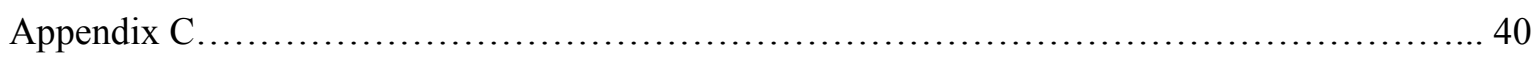

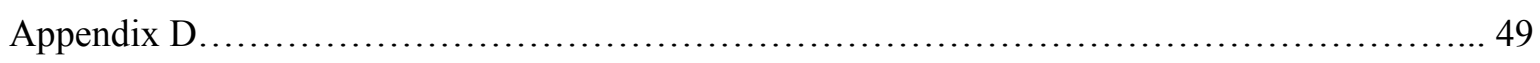




\section{FIGURES}

Figure 1. Map shows locations of the earthquake reporting area within a $161-\mathrm{km}$ (100 mile) radius around the INL, Quaternary faults, and volcanic rift zones.

Figure 2. Map shows the locations of INL seismic stations and stations monitored by INL that are operated by other institutions.

Figure 3. Map shows the number of strong-motion accelerogaphs located at INL facility areas or other locations.

Figure 4. Map shows locations of continuous GPS stations co-located at INL seismic stations and those operated by the Plate Boundary Observatory (PBO) under the EarthScope Science Program ........ 14

Figure 5. Map of epicenters of earthquakes for magnitudes greater than 3.0 during $2012 \ldots \ldots \ldots \ldots \ldots \ldots \ldots \ldots . . . . . . . . .22$

Figure 6. Map of epicenters of earthquakes within the $161-\mathrm{km}$ radius around the INL from January 1, 2012 to December 31, 2012.

Figure 7. Map shows epicenters of earthquakes at Craters of the Moon National Monument from 19992012

Figure 8. Map of epicenters of earthquakes from 1972 to 2012 within the $161-\mathrm{km}$ radius around the INL.

\section{TABLES}

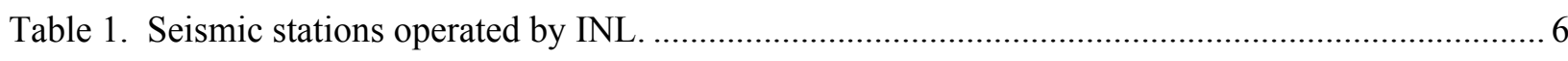

Table 2. Agencies and stations from which INL receives data shares............................................. 9

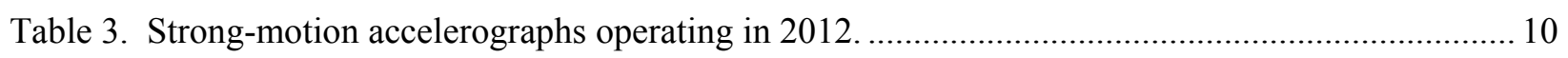

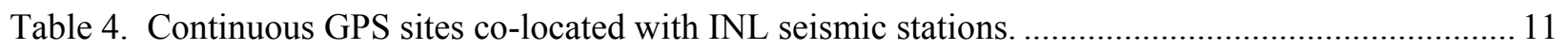

Table 5. P-wave velocity models used in location programs.................................................................. 19 
(Intentionally Blank) 


\section{ACRONYMS}

\begin{tabular}{|c|c|}
\hline ANL & Argonne National Laboratory \\
\hline ATR & Advanced Test Reactor \\
\hline CFA & Central Facilities Area \\
\hline $\mathrm{COM}$ & Craters of the Moon National Monument and Preserve \\
\hline DAAS & Data Acquisition/Analysis System \\
\hline DOE & Department of Energy \\
\hline DSL & Digital Subscriber Line \\
\hline EFS & Experimental Field Station \\
\hline ESRP & Eastern Snake River Plain \\
\hline GPS & Global Positioning System \\
\hline ICPP & Idaho Chemical Processing Plant \\
\hline INL & Idaho National Laboratory \\
\hline INTEC & Idaho Nuclear Technology and Engineering Center \\
\hline IP & Internet Protocol \\
\hline IRC & INL Research Center \\
\hline LOFT & Loss of Fluid Test \\
\hline MFC & Materials and Fuels Complex \\
\hline Mw & Moment Magnitude \\
\hline $\mathrm{M}_{\mathrm{c}}$ & Coda Magnitude \\
\hline $\mathrm{M}_{\mathrm{L}}$ & Local Magnitude \\
\hline $\mathrm{M}_{\mathrm{s}}$ & Surface-wave Magnitude \\
\hline NEIC & National Earthquake Information Center \\
\hline NRF & Naval Reactor Facility \\
\hline OFS & Old Fire Station \\
\hline
\end{tabular}




$\begin{array}{ll}\text { PBF } & \text { Power Burst Facility } \\ \text { PBO } & \text { Plate Boundary Observatory } \\ \text { P-wave } & \text { Compression Wave } \\ \text { REC } & \text { Research and Education Campus } \\ \text { RMS } & \text { Root Mean Square } \\ \text { RWMC } & \text { Radioactive and Waste Management Complex } \\ \text { S-wave } & \text { Shear Wave } \\ \text { SMC } & \text { Special Manufacturing Complex } \\ \text { SMA } & \text { Strong Motion Accelerograph } \\ \text { SSCs } & \text { Structures, Systems, and Components } \\ \text { TAN } & \text { Test Area North } \\ \text { TRA } & \text { Test Reactor Area } \\ \text { USGS } & \text { United States Geological Survey }\end{array}$




\section{INL Seismic Monitoring Annual Report: January 1, 2012 - December 31, 2012}

\section{Introduction}

The Idaho National Laboratory (INL) has accumulated 40 years of earthquake data (1972-2012). This report covers the earthquake activity from January 1, 2012 through December 31, 2012 and is a continuation of previous annual reports on earthquake activity surrounding the eastern Snake River Plain (ESRP) and within and near the INL. It discusses the earthquake activity that has occurred around the local region and within $161 \mathrm{~km}$ (or 100-miles) of the INL and centered at $43^{\circ} 39.00^{\prime} \mathrm{N}, 112^{\circ} 47.00^{\prime} \mathrm{W}$ (Figure 1). It discusses seismic station, strong-motion accelerograph (SMA), and continuous GPS (Global Positioning System) instrumentation used to record earthquake data and how the data are analyzed.

\subsection{History of INL Seismic Monitoring Program}

\subsubsection{Purpose}

The purpose of the INL Seismic Monitoring Program is to provide the INL with earthquake data and staff expertise to support the requirements set forth by Presidential executive orders, Department of Energy (DOE) directives, orders and standards, and the Nuclear Regulatory Commission for seismic safety of: Structures, Systems, and Components (SSCs); workers and the public; and operations at INL of reactors and waste management activities. The program supports safety of operations through continuous monitoring of earthquake activity, the development of INL seismic design criteria, assessments of seismic hazards for existing facilities and new facility siting, and early warning of potential future volcanic activity near INL. For example, the seismic monitoring is required by DOE Order 420.1C "Facility Safety" (DOE, 2012).

The INL Seismic Monitoring Program operates 27 permanent seismic stations for the purpose of determining the time, location, and size of earthquakes occurring in the vicinity of the INL. The seismic data are compiled to develop an historical database that defines the zones and frequency of earthquake activity. INL seismic stations of various network configurations have monitored earthquake activity since 1972 (Section A-1; Appendix). The current configuration includes seismic stations located within and around the INL near Quaternary normal faults and volcanic rift zones (Figure 1). Additionally, GPS receivers are co-located at 16 seismic stations for the purpose of determining rates of crustal deformation. GPS velocities are used to identify regions of higher crustal deformation rates (such as Yellowstone Caldera in Wyoming) relative to regions of lower deformation rates (e.g., Snake River Plain, Idaho).

The INL Seismic Monitoring Program currently operates 20 SMAs within and near facilities for the purpose of recording strong ground motions from local moderate or major earthquakes. Half of the SMAs are located within INL buildings to determine the response of these buildings to ground motions in the event of a large earthquake. The other SMAs are located at "free-field" sites (not within buildings) at INL facility areas and are used to determine the levels of earthquake ground motions at the ground (rock or soil) surface. SMAs or accelerometers are also co-located at seven INL seismic stations to record acceleration data and assess attenuation effects of small to large magnitude normal faulting earthquakes. SMAs were first installed in the 1970's and their facility locations have evolved based on the needs of facility operations (see Section A-2; Appendix A). 


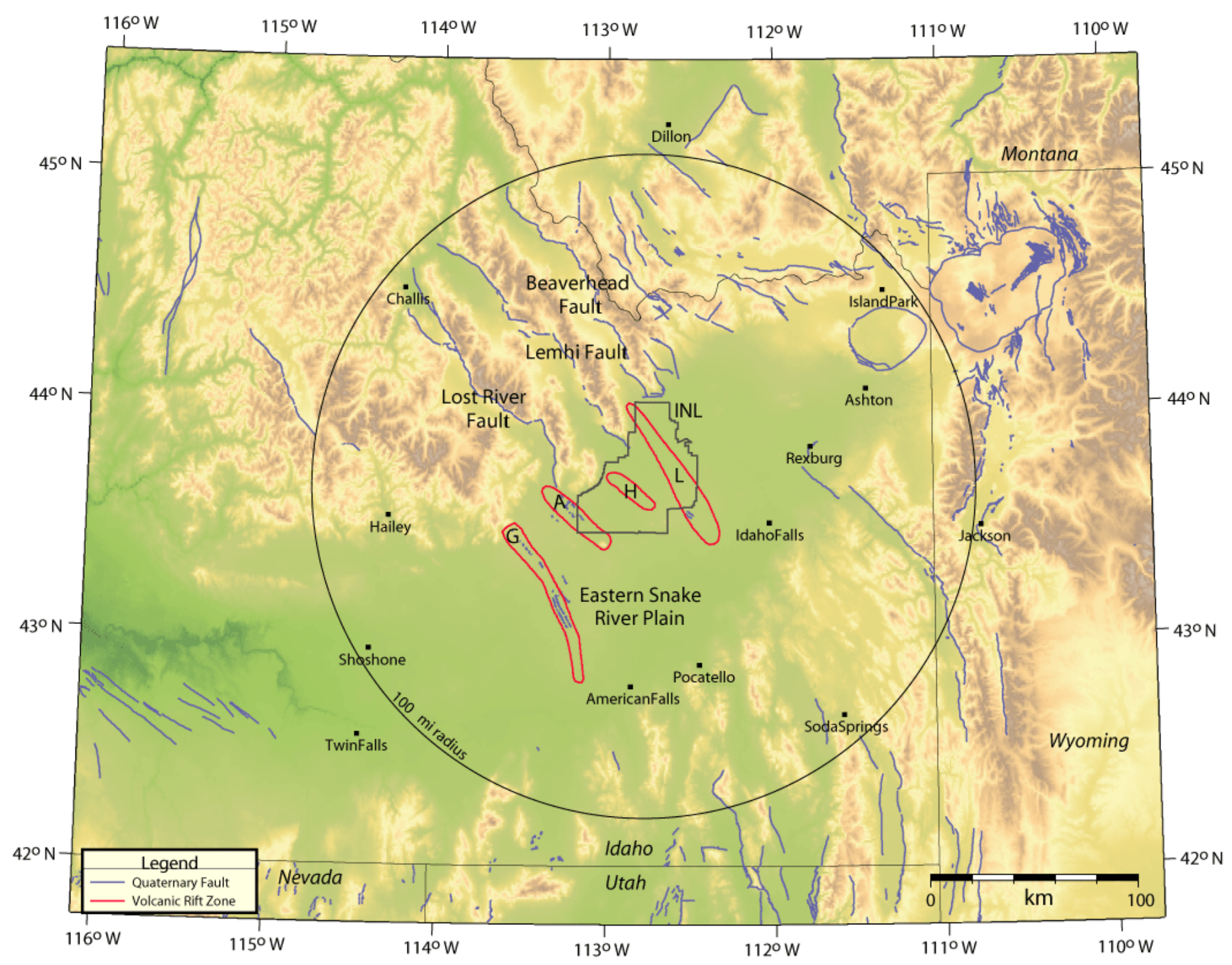

Figure 1. Map shows locations of the earthquake reporting area within a 161-km (100 mile) radius around the INL, Quaternary faults, and volcanic rift zones: G - Great Rift, A - Arco, H - Howe-East Butte, and L - Lava Ridge-Hell's Half Acre. 


\section{Instrumentation}

\subsection{Seismic Station Network}

During 2012, the INL Seismic Monitoring Program operated 27 permanent seismic stations and monitored up to 50 seismic stations from other nearby seismic networks (Figure 2). Table 1 lists the name, location, and date of installation for the seismic stations owned and operated by the INL Seismic Monitoring Program. Table 2 lists the name, location, and operation dates of seismic stations owned by other agencies. The INL recorded seismic data from these other seismic stations to improve the quality of earthquake locations within the 161-km radius of INL.

Instrumentation for INL seismic stations consists of digital recorders, one- and three-component seismometers, and three-component accelerometers. The digital recorder is a DAQSystems NetDAS field unit, which is an embedded LINUX computer with a GPS clock and Symmetric Research 24 bit digitizer. The NetDAS units have from 22 to 24 bits of data resolution over \pm 20 volts for a four-channel unit or \pm 10 volts for an eight-channel unit. Four channel units (NetDAS-CH4) are located at seismic stations that have one or three sensors; eight channel units (NetDAS-CH8) are at seismic stations that have more than three sensors (such as three seismometers and three accelerometers). The NetDAS digitizes data at the seismic station and time stamps the data with accuracies of \pm 0.001 seconds. The seismic signals are transmitted by FreeWave Technologies DGR115 $900 \mathrm{MHz}$ Wireless Modem radios. These radios use standard IP (Internet Protocol) networking features that are included in their embedded LINUX operating system.

The INL Seismic Monitoring program includes short-period and broadband seismometers and accelerometers (Table 1). Single-component short-period seismic stations have vertically oriented velocity sensors (or seismometers) that are a Mark Products model L-4C, Teledyne Geotech (TG) model S-13, or TG model S-13 Jr. seismometer. All seismic stations located within the ESRP have their verticalcomponent seismometer located at the bottom of $18-\mathrm{m}$ or greater borehole to help dampen wind and cultural noise (Seismic, 1993). Seismometers at stations outside of the ESRP are buried within $3 \mathrm{~m}$ of the ground surface. Seismic stations with horizontally-oriented velocity sensors have two Teledyne Geotech model S-13 seismometers located within a concrete vault, in addition to the vertically-oriented sensor. Seismic stations with acceleration sensors have Applied MEMs Inc. model SF1500A, SF2500A, or SF3000L tri-axial accelerometers.

Two INL stations include three-component broadband seismometers, the New Production Reactor, Idaho (NPRI) and Crow's Nest Canyon, Idaho (CNCI) seismic station (Table 1). The INL acquired the broadband seismograph station I14A from the EarthScope project (Earthscope, 2007). The broadband sensor is co-located with the CNCI short-period seismic sensor. Instrumentation at CNCI includes a Quanterra Q330 data acquisition system and Guralp CMG-3T three-component broadband seismometer. The instrumentation remains in the original vault installed by USArray. The NPRI station was upgraded in 2011 to include broadband seismic monitoring capabilities as first step to upgrade additional INL seismic stations. The instrumentation at NPRI consists of a Quanterra Q330-SR data acquisition system and a three-component, Nanometrics Trillium T120-PA broadband seismometer. The instrumentation is housed within a vault-like enclosure covered by native soils to dampen wind noise and reduce temperature fluctuations.

Where AC power is not available, seismic stations are powered by batteries, solar panels, and at some locations, small wind generators. Radio frequency compatible antennas transmit and receive the seismic signals. Several seismic stations are used as relay stations to allow transmission of seismic signals to the INL Research Center (IRC) at the Research and Education Campus (REC) in Idaho Falls. The 
seismic data are relayed by digital radios or internet Digital Subscriber Line (DSL) links (Section A-4; Appendix A). The data are acquired through EARTHWORM software over the Internet (discussed in Section 2.5). In the "Seismic Lab" at the IRC, digital seismograms are continuously displayed on four computer monitors referred to as "Webicorders."

\subsection{Strong Motion Accelerographs}

The INL accelerograph network currently consists of 20 strong-motion accelerographs: 19 are at facilities at the INL Site and one is located in the IRC. There are one to three accelerographs at each INL Site facility area (Figure 3). Additionally, since 2008, INL has operated one SMA outside of the INL boundary co-located at the COMI seismic station. Table 3 lists the location and date of installation for each of the SMAs in operation. During 2012, earthquakes did not trigger SMAs located within INL facilities.

INL SMAs are DAQSystems NetDAS digital accelerographs that have Applied MEMS SiFlex SF2500 tri-axial accelerometers mounted within the unit. Each accelerometer component of an SMA is set to trigger and record to compact flash when ground motions exceed $\sim 0.005 \mathrm{~g}$ except for the SMA in the basement of ATR (TRA2) which is set to $\sim 0.0005 \mathrm{~g}$. The record lengths are set for $30 \mathrm{~s}$ of pre- and post-trigger thresholds. The tri-axial accelerometers have two horizontal components oriented in an orthogonal manner, generally aligned in the north-south and east-west directions. Appendix B lists the accelerometer orientation and instrument response for the horizontal and vertical components of each SMA. SMAs at free-field sites have GPS clocks to synchronize the internal clocks to an absolute time system. For some SMAs at free-field sites and locations within buildings, acceleration data are transmitted to the IRC via digital radios or the Internet. Other SMAs record data on compact flash disks that are retrieved by INL seismic personnel using a laptop computer.

\subsection{Continuous GPS Stations}

The INL Seismic Monitoring Program has a geodetic network for the purpose of monitoring crustal deformation in support of INL seismic hazards assessments. The network consists of 16 GPS receivers and antennas co-located with INL seismic stations. As part of the Plate Boundary Observatory (PBO) under the EarthScope Science Program, there are currently 19 other continuous GPS sites near the Snake River Plain (Figure 4). One of these GPS receivers is co-located at INL's Great Rift, Idaho (GTRI) seismic station. In addition to continuously operating GPS sites, INL personnel collected GPS phase data at several campaign GPS sites.

An INL continuous GPS station consists of a Trimble NetRS GPS receiver connected to a Trimble $\mathrm{L} 1 / \mathrm{L} 2$ dual frequency choke ring antenna. The antenna is attached to a $2.4 \mathrm{~m}$ steel rod that is drilled into a rock outcrop to a depth of about $1 \mathrm{~m}$. The NetRS receivers continuously collect GPS phase data (positions of 20 satellites) at 30 seconds intervals. The phase data are relayed along with the seismic station data to DSL links, which are then accessed from the Internet at the IRC. Also, the phase data are downloaded daily from the Internet and archived by UNAVCO, ${ }^{\mathrm{TM}}$ a non-profit university-governed consortium.

During 2012, INL collected GPS phase data and teamed with Dr. Robert King at the Massachusetts Institute of Technology to process INL GPS phase data. Dr. King processed all of INL's GPS phase data acquired up to 2012 and located within the ESRP and surrounding Basin and Range. He combined the INL GPS data with other data in the region to produce a horizontal GPS velocity field that encompasses the Pacific Northwest.

GPS data are used to investigate active crustal deformation that is on the order of millimeters of movement per year within the ESRP, the surrounding Basin and Range, and Yellowstone Caldera. GPS 
data help distinguish regions of high velocity gradients (or strain rates) having more frequent damaging earthquakes (e.g., Yellowstone - Hebgen Lake, Montana) from regions of low velocity gradients (e.g., eastern Snake River Plain). The regional spatial patterns of GPS data also help constrain the fundamental geodynamic processes that drive active continental deformation in the western United States. Locally, the horizontal GPS velocities indicate the Basin and Range is rapidly extending at a rate greater than the very slowly deforming Snake River Plain, which is thought to explain its relative low seismicity (e.g., Payne et al. 2012; Payne et al., 2013).

\subsection{Seismic Data Acquisition and Analysis System}

The INL records earthquake data on a computer Data Acquisition/Analysis System (DAAS) at the IRC, which has evolved since 1991 (see Section A-3; Appendix A). The DAAS employs two major software packages: EARTHWORM, which is used to perform earthquake detection and recording; and SEISAN, which is used to analyze earthquakes (see Section 3). EARTHWORM performs two primary functions that include signal discrimination for possible earthquakes and data sharing with other seismic networks. Additionally, the DAAS has a dedicated computer (or Vault) that routinely backup files on the acquisition and analysis computers and archives all digital earthquake data after analysis.

EARTHWORM constantly monitors seismic signals from INL seismic stations by evaluating the amplitude ratios of the short-term average divided by the long-term average (STA/LTA). This involves comparing the short-term root-mean square (RMS) average (1-s window) of the seismic data to a longerterm RMS average, which is the background noise or voltage level determined over a time interval of 20 s. The program determines that an earthquake has occurred when the STA/LTA ratios for several stations exceed a threshold value. When an earthquake is detected, seismograms are saved in a file on a disk. This file is labeled with a sequential number based on the date and time of the trigger. The trigger files are entered into the SEISAN database and are available for analysis in SEISAN. Each seismogram has $30 \mathrm{~s}$ of pre-event data and $20 \mathrm{~s}$ of post-event data stored within the file. The pre- and post-event durations ensure the entire earthquake waveform is recorded. In some instances, earthquakes have low-amplitudes, emergent compression (P) waves with larger amplitude shear (S) waves. When this occurs the DAAS may trigger on the S-waves instead of the P-waves, thus, saving $30 \mathrm{~s}$ of pre-event time allows recording of the P-waves also.

The earthquake detection software is configured to trigger on earthquakes detected by several stations within a subnet. Subnets contain several stations that are likely to detect the same local earthquake. All INL seismic stations usually detect local earthquakes of magnitude 1.5. Subnets are specified for stations in close proximity to each other and their relationship to known seismic sources. For the ESRP though, a subnet was created for detection of small magnitude $(\mathrm{M}<0.5)$ microearthquakes.

The EARTHWORM software also enables data sharing with other seismic networks in near real time over the Internet. The INL provides data from various seismic stations to the University of Utah, Montana Bureau of Mines and Geology, and National Earthquake Information Center (NEIC), which in return provide data to INL (Table 2). EARTHWORM triggers on and records seismic data from INL and these other agencies. Analyzing earthquake data from these other seismic stations in SEISAN, expands azimuth coverage of earthquakes resulting in reduced uncertainties of earthquake locations and magnitudes within the $161-\mathrm{km}$ radius of INL. 
Table 1. Seismic stations operated by INL.

\begin{tabular}{|c|c|c|c|c|c|c|}
\hline Code & Station Name & Types of Sensors & $\begin{array}{l}\text { Latitude } \\
\text { North } \\
\left({ }^{\circ}\right) \\
\end{array}$ & $\begin{array}{l}\text { Longitude } \\
\text { West } \\
\left(^{\circ}\right) \\
\end{array}$ & $\begin{array}{l}\text { Elevation } \\
(\mathrm{m})\end{array}$ & $\begin{array}{c}\text { Date } \\
\text { Installed } \\
\text { (Month/Year) }\end{array}$ \\
\hline ARNI & $\begin{array}{l}\text { Argonne North, } \\
\text { Idaho }\end{array}$ & $\begin{array}{c}\text { Borehole Vertical } \\
\text { Seismometer; GPS } \\
\text { Receiver }\end{array}$ & 43.6667 & 112.6235 & 1533 & 09/1990 \\
\hline BCYI & Bear Canyon, Idaho & $\begin{array}{l}\text { Vertical } \\
\text { Seismometer; } \\
\text { Three-component } \\
\text { Accelerometers; } \\
\text { GPS Receiver }\end{array}$ & 44.3108 & 113.4052 & 2194 & 05/1992 \\
\hline CBTI & Cedar Butte, Idaho & $\begin{array}{l}\text { Borehole Vertical } \\
\text { Seismometer }\end{array}$ & 43.3875 & 112.9115 & 1734 & $07 / 1986$ \\
\hline COMI & $\begin{array}{l}\text { Craters of the Moon, } \\
\text { Idaho }\end{array}$ & $\begin{array}{l}\text { Three-component } \\
\text { Seismometers; } \\
\text { Strong-Motion } \\
\text { Accelerograph }\end{array}$ & 43.4618 & 113.5938 & 1890 & 03/1992 \\
\hline CNCI & $\begin{array}{c}\text { Crows Nest Canyon, } \\
\text { Idaho }\end{array}$ & $\begin{array}{l}\text { Vertical (Short- } \\
\text { period) } \\
\text { Seismometer; } \\
\text { Three-component } \\
\text { Broadband } \\
\text { Seismometers }\end{array}$ & 43.9283 & 113.4522 & 1914 & 05/1992 \\
\hline CRBI & $\begin{array}{l}\text { Circular Butte, } \\
\text { Idaho }\end{array}$ & $\begin{array}{c}\text { Borehole Vertical } \\
\text { Seismometer; GPS } \\
\text { Receiver }\end{array}$ & 43.8303 & 112.6345 & 1520 & $11 / 1987$ \\
\hline ECRI & Eagle Creek, Idaho & $\begin{array}{c}\text { Vertical } \\
\text { Seismometer }\end{array}$ & 43.0535 & 111.3705 & 2086 & 08/1994 \\
\hline EMI & $\begin{array}{l}\text { Eightmile Canyon, } \\
\text { Idaho }\end{array}$ & $\begin{array}{c}\text { Vertical } \\
\text { Seismometer; GPS } \\
\text { Receiver }\end{array}$ & 44.0742 & 112.9262 & 1963 & 04/1992 \\
\hline GBI & $\begin{array}{c}\text { Big Grassy Butte, } \\
\text { Idaho }\end{array}$ & $\begin{array}{l}\text { Borehole Vertical } \\
\text { Seismometer; GPS } \\
\text { Receiver }\end{array}$ & 43.9875 & 112.0633 & 1541 & 10/1981 \\
\hline GRRI & Grays Range, Idaho & $\begin{array}{l}\text { Vertical } \\
\text { Seismometer; } \\
\text { Three-component } \\
\text { Accelerometers; } \\
\text { GPS Receiver }\end{array}$ & 42.9380 & 111.4217 & 2207 & 08/1994 \\
\hline GTRI & Great Rift, Idaho & $\begin{array}{c}\text { Borehole Vertical } \\
\text { Seismometer; GPS } \\
\text { Receiver }^{\mathrm{a}}\end{array}$ & 43.2440 & 113.2410 & 1522 & 05/1992 \\
\hline
\end{tabular}


Table 1. Continued.

\begin{tabular}{|c|c|c|c|c|c|c|}
\hline Code & Station Name & Types of Sensors & $\begin{array}{l}\text { Latitude } \\
\text { North } \\
\left({ }^{\circ}\right) \\
\end{array}$ & $\begin{array}{l}\text { Longitude } \\
\text { West } \\
\left({ }^{\circ}\right) \\
\end{array}$ & $\begin{array}{c}\text { Elevation } \\
(\mathrm{m})\end{array}$ & $\begin{array}{c}\text { Date } \\
\text { Installed } \\
\text { (Month/Year) }\end{array}$ \\
\hline HHAI & $\begin{array}{l}\text { Hell's Half Acre, } \\
\text { Idaho }\end{array}$ & $\begin{array}{l}\text { Borehole Vertical } \\
\text { Seismometer }\end{array}$ & 43.2950 & 112.3795 & 1371 & $06 / 1992$ \\
\hline HPI & Howe Peak, Idaho & $\begin{array}{c}\text { Vertical } \\
\text { Seismometer; GPS } \\
\text { Receiver }\end{array}$ & 43.7113 & 113.0983 & 2597 & $10 / 1972$ \\
\hline HWFI & Howe Fault, Idaho & $\begin{array}{l}\text { Three-component } \\
\text { Seismometers; } \\
\text { Three-component } \\
\text { Accelerometers; } \\
\text { GPS Receiver }\end{array}$ & 43.9257 & 113.0973 & 1743 & $10 / 1999$ \\
\hline ICI & $\begin{array}{l}\text { Italian Canyon, } \\
\text { Idaho }\end{array}$ & $\begin{array}{c}\text { Vertical } \\
\text { Seismometer; GPS } \\
\text { Receiver }\end{array}$ & 44.3293 & 112.9412 & 2463 & 04/1992 \\
\hline IRCI & $\begin{array}{l}\text { INL Research } \\
\text { Center, Idaho }\end{array}$ & $\begin{array}{c}\text { Low-gain } \\
\text { Three-component } \\
\text { Seismometers }\end{array}$ & 43.5153 & 112.0333 & 1442 & $11 / 1988$ \\
\hline JGI & $\begin{array}{l}\text { Juniper Gulch, } \\
\text { Idaho }\end{array}$ & $\begin{array}{c}\text { Three-component } \\
\text { Seismometers }\end{array}$ & 44.0927 & 112.6768 & 1657 & $11 / 1979$ \\
\hline KBI & Kettle Butte, Idaho & $\begin{array}{l}\text { Borehole Vertical } \\
\text { Seismometer }\end{array}$ & 43.5907 & 112.3767 & 1678 & $05 / 1992$ \\
\hline LJI & $\begin{array}{l}\text { Lemhi Junction, } \\
\text { Idaho }\end{array}$ & $\begin{array}{c}\text { Vertical } \\
\text { Seismometer }\end{array}$ & 43.8208 & 112.8440 & 1643 & 05/1990 \\
\hline LLRI & $\begin{array}{l}\text { Little Lost River, } \\
\text { Idaho }\end{array}$ & $\begin{array}{l}\text { Three-component } \\
\text { Seismometers; } \\
\text { GPS Receiver }\end{array}$ & 43.7230 & 112.9330 & 1476 & 05/1990 \\
\hline NPRI & $\begin{array}{l}\text { New Production } \\
\text { Reactor, Idaho }\end{array}$ & $\begin{array}{l}\text { Three-component } \\
\text { Short-period \& } \\
\text { Broadband } \\
\text { Seismometers; } \\
\text { Three-component } \\
\text { Accelerometers; } \\
\text { GPS Receiver }\end{array}$ & 43.5975 & 112.8272 & 1495 & 09/1990 \\
\hline PTI & Pocatello, Idaho & $\begin{array}{l}\text { Vertical } \\
\text { Seismometer; } \\
\text { Three-component } \\
\text { Accelerometers; } \\
\text { GPS Receiver }\end{array}$ & 42.8703 & 112.3702 & 1670 & $10 / 1984$ \\
\hline PZCI & $\begin{array}{c}\text { Patelzick Creek, } \\
\text { Idaho }\end{array}$ & $\begin{array}{c}\text { Vertical } \\
\text { Seismometer; GPS } \\
\text { Receiver }\end{array}$ & 44.3410 & 112.3172 & 2073 & 12/1991 \\
\hline
\end{tabular}


Table 1. Continued.

\begin{tabular}{|c|c|c|c|c|c|c|}
\hline Code & Station Name & Types of Sensors & $\begin{array}{l}\text { Latitude } \\
\text { North } \\
\left({ }^{\circ}\right) \\
\end{array}$ & $\begin{array}{l}\text { Longitude } \\
\text { West } \\
\left({ }^{\circ}\right) \\
\end{array}$ & $\begin{array}{c}\text { Elevation } \\
(\mathrm{m})\end{array}$ & $\begin{array}{c}\text { Date } \\
\text { Installed } \\
\text { (Month/Year) }\end{array}$ \\
\hline SMBI & Sixmile Butte, Idaho & $\begin{array}{l}\text { Borehole Vertical } \\
\text { Seismometer }\end{array}$ & 43.5022 & 113.2677 & 1716 & 05/1992 \\
\hline SPCI & Split Crater, Idaho & $\begin{array}{l}\text { Three-component } \\
\text { Seismometers; } \\
\text { Three-component } \\
\text { Accelerometers }\end{array}$ & 43.4500 & 112.6370 & 1553 & 06/1992 \\
\hline TCSI & $\begin{array}{l}\text { Telchick Spring, } \\
\text { Idaho }\end{array}$ & $\begin{array}{c}\text { Vertical } \\
\text { Seismometer; GPS } \\
\text { Receiver }\end{array}$ & 43.6193 & 113.4783 & 1731 & $05 / 1992$ \\
\hline TMI & $\begin{array}{l}\text { Taylor Mountain, } \\
\text { Idaho }\end{array}$ & $\begin{array}{l}\text { Three-component } \\
\text { Seismometers; } \\
\text { GPS Receiver }\end{array}$ & 43.3057 & 111.9182 & 2179 & $10 / 1972$ \\
\hline
\end{tabular}

a. - GPS instrumentation is owned by the Plate Boundary Observatory under the EarthScope Science Program. 
Table 2. Agencies and stations from which INL receives data shares.

\begin{tabular}{|c|c|c|c|c|}
\hline Code & Station Name & Latitude North $\left(^{\circ}\right)$ & Longitude West $\left({ }^{\circ}\right)$ & Elevation $(\mathrm{m})$ \\
\hline \multicolumn{5}{|c|}{ National Earthquake Information Center, Golden, Colorado } \\
\hline AHID & Auburn, Idaho & 42.7653 & 111.1003 & 1960 \\
\hline $\mathrm{BMO}$ & Baker City, Oregon & 44.8525 & 117.3060 & 1154 \\
\hline BW06 & Boulder, Wyoming & 42.7667 & 109.5582 & 2224 \\
\hline DLMT & Dillon, MT & 45.3625 & -112.5964 & 1569 \\
\hline FLWY & Flagg Ranch, WY & 44.0827 & -110.6993 & 2078 \\
\hline FXWY & Fox Creek, WY & 43.6381 & -111.0268 & 2254 \\
\hline HLID & Hailey, Idaho & 43.5625 & 114.4063 & 1498 \\
\hline IMW & Indian Meadows, Wyoming & 43.8970 & -110.9392 & 2646 \\
\hline LOHW & Long Hollow, Wyoming & 43.6123 & -110.6037 & 2121 \\
\hline MFID & Camas Ranch, Mayfield, ID & 43.4151 & -115.8278 & 1302 \\
\hline PLID & Pearl Lake, ID & 45.0877 & -116.0002 & 2164 \\
\hline REDW & Red Top Meadow, Wyoming & 43.3642 & -110.8518 & 2322 \\
\hline TPAW & Teton Pass, Wyoming & 43.4902 & -110.9507 & 2512 \\
\hline \multicolumn{5}{|c|}{ University of Utah, Salt Lake City, Utah } \\
\hline BEI & Bear River Range, Idaho & 42.1167 & 111.7823 & 1859 \\
\hline BMUT & Black Mountain, Utah & 41.9582 & 111.2342 & 2243 \\
\hline H17A & Transportable Array Site & 44.3951 & -110.5762 & 2400 \\
\hline MCID & Moose Creek, Idaho & 44.1903 & 111.1827 & 2149 \\
\hline MLI & Malad Range, Idaho & 42.0268 & 112.1255 & 1896 \\
\hline NPI & North Pocatello, Idaho & 42.1473 & 112.5183 & 1640 \\
\hline YMC & Maple Creek, Wyoming & 44.7593 & 111.0062 & 2073 \\
\hline YPP & Pitchstone Plateau, Wyoming & 44.2710 & 110.8045 & 2707 \\
\hline \multicolumn{5}{|c|}{ Montana Bureau of Mines and Geology, Butte, Montana } \\
\hline MCMT & McKenzie Canyon, Montana & 44.8277 & 112.8488 & 2323 \\
\hline MOMT & Monida, Montana & 44.5933 & 112.3943 & 2220 \\
\hline TPMT & Teepee Creek, Montana & 44.7298 & 111.6657 & 2518 \\
\hline
\end{tabular}


Table 3. Strong-motion accelerographs operating in 2012.

\begin{tabular}{ccccc}
\hline Site Location $^{\mathrm{a}}$ & Building Number $^{\mathrm{a}}$ & Location & Site Code & Year Installed \\
\hline MFC & ANL-767 & Basement & EBR1 & 1973 \\
MFC & ANL-768 & Basement & FCF1 & 1973 \\
CFA & CFA-1607 & Free-field & CFA & 1996 \\
EFS & EFS & Free-field & PHFF & 2010 \\
COMI & NA & Free-field & COMF & 2008 \\
INTEC & CPP-666 & Second Floor & FAS1 & 1984 \\
INTEC & CPP-666 & Second Basement & FAS2 & 1984 \\
NRF & NRF-768 & Free-field & NRFF & 1996 \\
NRF & NRF-A1W & First Floor & A1W & 1983 \\
NRF & NRF-S1W & First Floor & S1W & 1983 \\
PBF & NA & Free-field & PBFF & 2005 \\
PBF & NA & Free-field & ARAF & 2005 \\
ATR & TRA-602 & Free-field & TRAF & 2003 \\
ATR & TRA-670 & Basement & TRAB & 1996 \\
RWMC & NA & Free-field & RWMC & 1997 \\
RWMC & NA & Free-field & RWME & 2005 \\
REC & IF-602 & First Floor & IRC & 1983 \\
TAN & NA & Free-field & TANA & 2007 \\
TAN & TAN-601 & First Floor & TAN4 & 2008 \\
TAN & SMC & First Floor & SMC & 2007 \\
\hline NA Not & & &
\end{tabular}

NA - Not within a building.

a. Acronyms: ANL - Argonne National Laboratory; ATR - Advanced Test Reactor; CFA - Central Facilities Area; COMI - Craters of the Moon seismic station (Table 1); CPP - Chemical Processing Plant; EFS - Experimental Field Station; IF - Idaho Falls; INTEC - Idaho Nuclear Technology and Engineering Center; MFC - Materials and Fuels Complex; NRF - Naval Reactors Facility; PBF - Power Burst Facility; RWMC - Radioactive and Waste Management Complex; SMC - Special Manufacturing Complex; TAN - Test Area North; TRA - Test Reactor Area. 
Table 4. Continuous GPS sites co-located with INL seismic stations.

\begin{tabular}{|c|c|c|c|c|c|}
\hline Code & Station Name & $\begin{array}{l}\text { Latitude } \\
\text { North }\left(^{\circ}\right)\end{array}$ & $\begin{array}{l}\text { Longitude } \\
\text { West }\left(\left(^{\circ}\right)\right.\end{array}$ & $\begin{array}{l}\text { Elevation } \\
\text { (m) }\end{array}$ & Year Installed \\
\hline ARNG & Argonne North, Idaho & 43.6667 & 112.6235 & 1533 & 2005 \\
\hline BCYI & Bear Canyon, Idaho & 44.3108 & 113.4052 & 2194 & 2003 \\
\hline CRBG & Circular Butte, Idaho & 43.8303 & 112.6345 & 1520 & $2007^{\mathrm{a}}$ \\
\hline EMIG & Eightmile Canyon, Idaho & 44.0742 & 112.9262 & 1963 & 2005 \\
\hline GBIG & Big Grassy Butte, Idaho & 43.9875 & 112.0633 & 1541 & $2007^{\mathrm{a}}$ \\
\hline GRRG & Grays Range, Idaho & 42.9380 & 111.4217 & 2207 & $2007^{\mathrm{a}}$ \\
\hline GTRG & Great Rift, Idaho & 43.2440 & 113.2410 & 1522 & $1998^{\mathrm{b}}$ \\
\hline HPIG & Howe Peak, Idaho & 43.7113 & 113.0983 & 2597 & 2005 \\
\hline HWFG & Howe Fault, Idaho & 43.9257 & 113.0973 & 1743 & $2007^{\mathrm{a}}$ \\
\hline ICIG & Italian Canyon, Idaho & 44.3293 & 112.9412 & 2463 & 2007 \\
\hline LLRG & Little Lost River, Idaho & 43.7230 & 112.9330 & 1476 & 2009 \\
\hline NPRG & $\begin{array}{c}\text { New Production Reactor, } \\
\text { Idaho }\end{array}$ & 43.5975 & 112.8272 & 1495 & 2009 \\
\hline PTIG & Pocatello, Idaho & 42.8703 & 112.3702 & 1670 & $2007^{\mathrm{a}}$ \\
\hline $\mathrm{PZCG}$ & Patelzick Creek, Idaho & 44.3410 & 112.3172 & 2073 & $2007^{\mathrm{a}}$ \\
\hline TCSG & Telchick Spring, Idaho & 43.6193 & 113.4783 & 1731 & 2005 \\
\hline TMIG & Taylor Mountain, Idaho & 43.3057 & 111.9182 & 2179 & $2007^{\mathrm{a}}$ \\
\hline \multicolumn{6}{|c|}{$\begin{array}{l}\text { a - Although hardware was installed for the GPS receiver in 2007, the receiver began acquiring phase data in } \\
2008 \text {. } \\
\text { b - Co-located at INL's seismic station GTRI, but operated by the Plate Boundary Observatory under the } \\
\text { EarthScope Science Program. }\end{array}$} \\
\hline
\end{tabular}




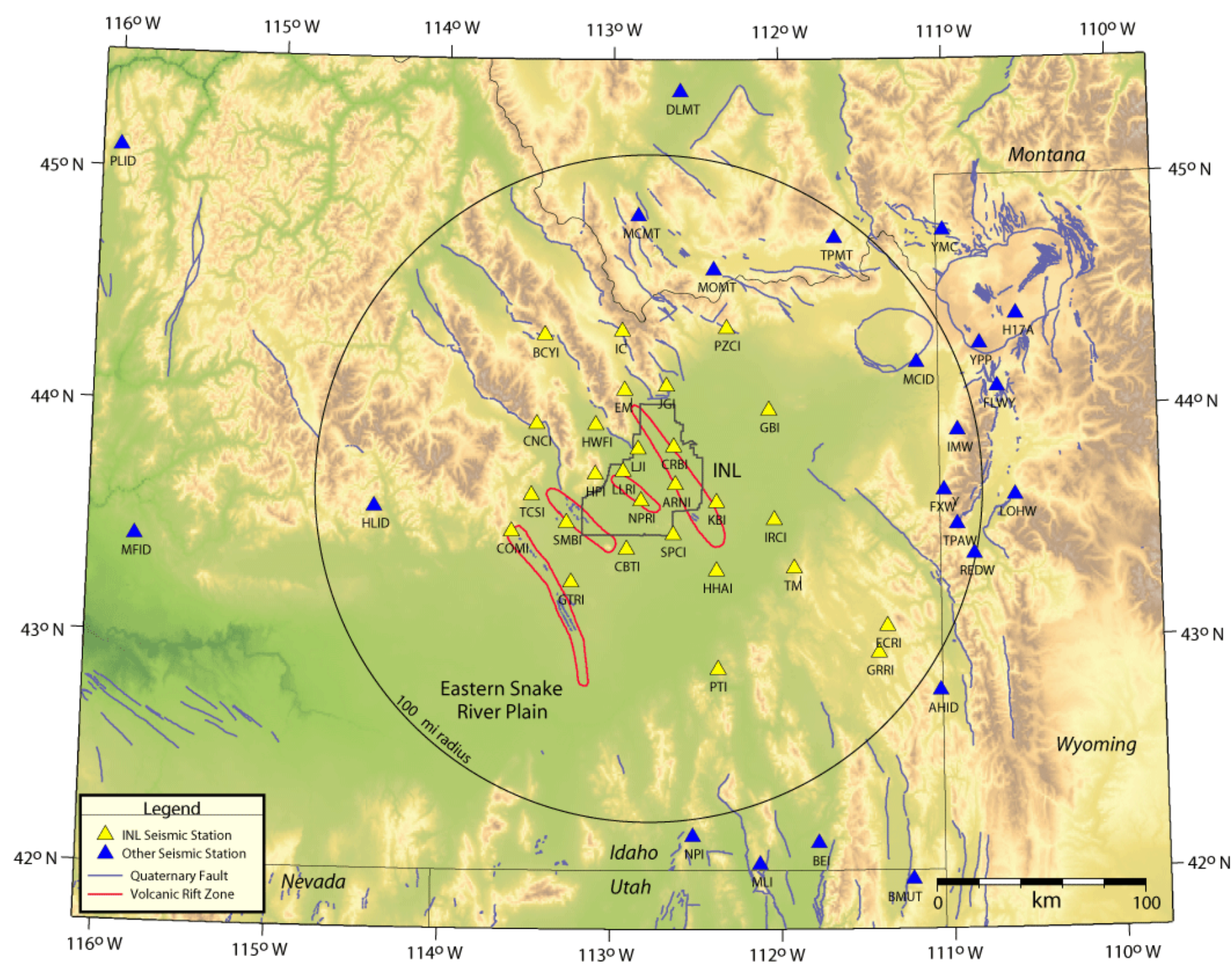

Figure 2. Map shows the locations of INL seismic stations and stations monitored by INL that are operated by other institutions. See Figure 1 for names of normal faults and volcanic rift zones. Stations BMO and BWO6 are not shown (see Table 2 for locations). 


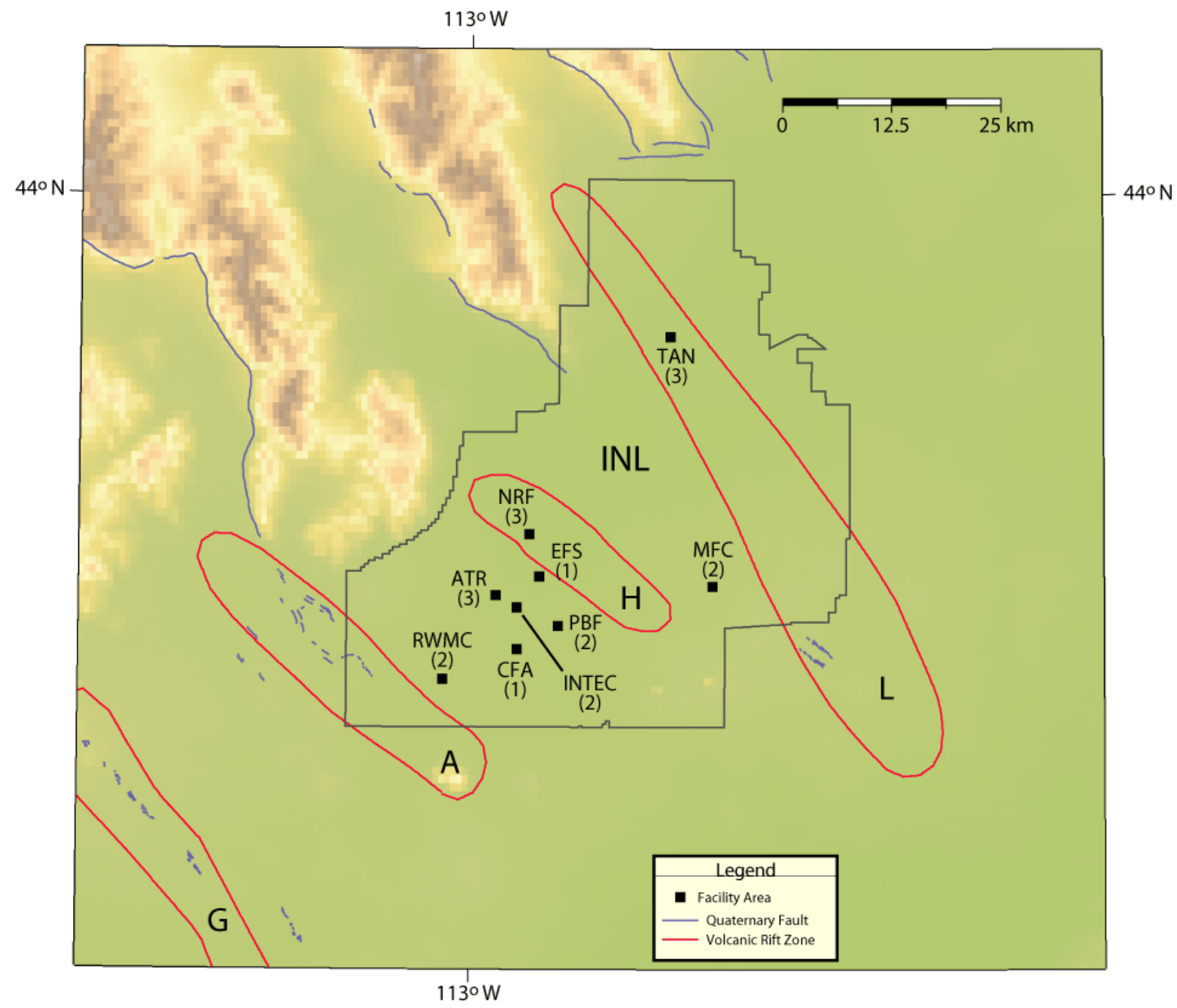

Figure 3. Map shows the number (in parentheses) of strong-motion accelerogaphs located at INL facility areas or other locations: Advanced Test Reactor (ATR), Central Facilities Area (CFA), Experimental Field Station (EFS), Idaho Nuclear Technology and Engineering Center (INTEC), Materials and Fuel Complex (MFC), Naval Reactors Facility (NRF), Radioactive Waste Management Complex (RWMC), and Test Area North (TAN). See Figure 1 for names of normal faults and abbreviations of volcanic rift zones. 


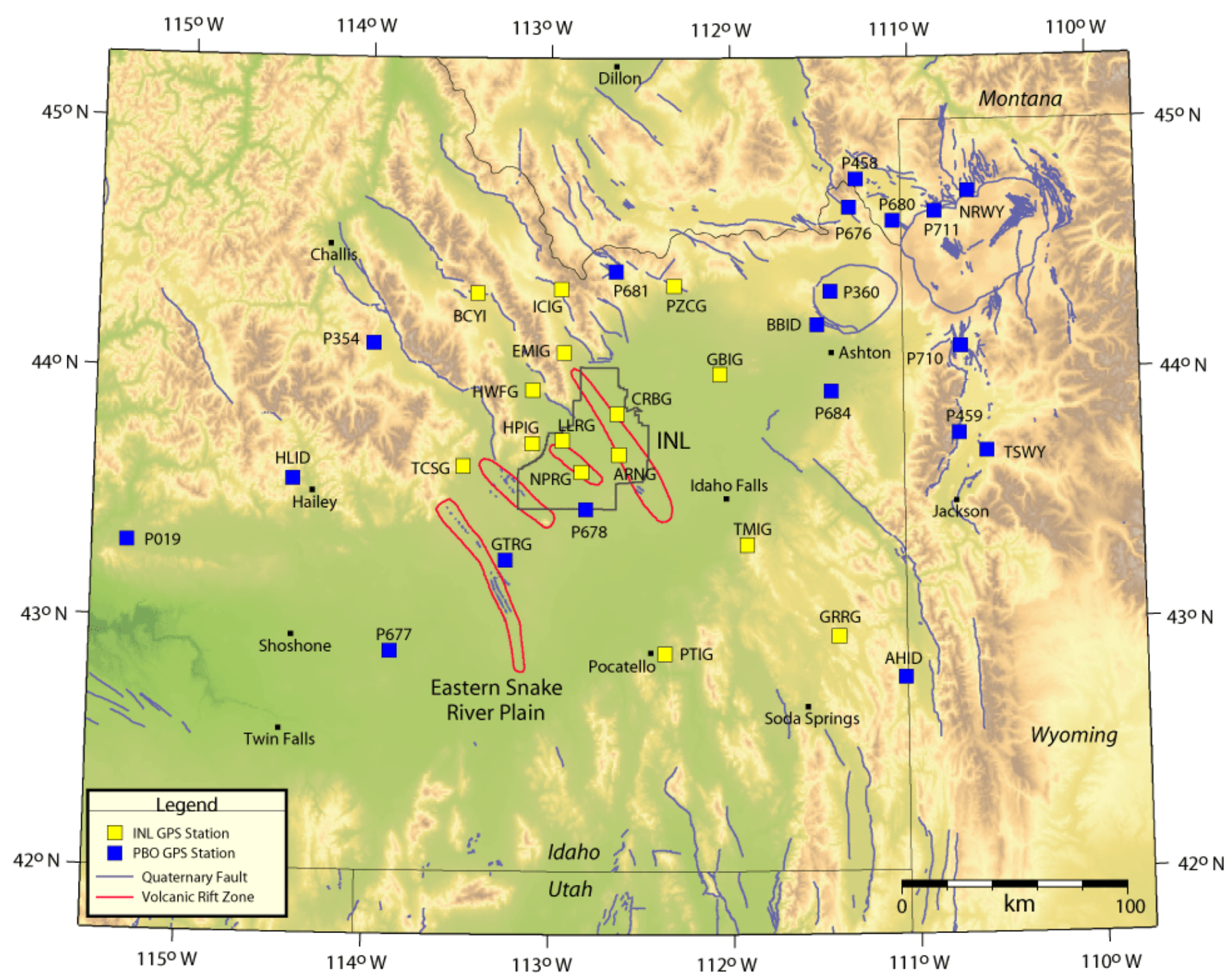

Figure 4. Map shows locations of continuous GPS stations co-located at INL seismic stations and those operated by the Plate Boundary Observatory (PBO) under the EarthScope Science Program. See Figure 1 for names of normal faults and volcanic rift zones. 


\section{Data Analysis}

Digital seismograms are analyzed using the SEISAN program to determine the earthquake's location, magnitude, and peak ground accelerations. SEISAN displays multiple seismograms on a computer screen with corresponding time codes having accuracy of $\pm 0.001 \mathrm{~s}$. P- and S-wave arrival times in the seismograms are selected at an accuracy of up to $\pm 0.01 \mathrm{~s}$. Durations and amplitudes of seismic signals are selected and then used to calculate earthquake magnitudes. The arrival times, durations, and amplitudes measured for an earthquake are saved in a computer file directly from the SEISAN program. Instrument responses of the NetDAS units and sensors at seismic stations and SMAs are now routinely determined and are integrated into the SEISAN database (see Appendices B and C). Earthquakes are located using the HYPOINVERSE-2000 program and two methods may be used to calculate the final magnitude of an earthquake depending on its size. The locations and magnitudes of the earthquakes are plotted on maps to assess seismically active regions near the INL. When available from a large magnitude earthquake, amplitudes of accelerograms can be measured using the SEISAN program then processed using a separate program to determine peak horizontal and vertical accelerations.

\subsection{Location Method}

The HYPOINVERSE-2000 location program (Klein, 2002) is used to determine locations for all local earthquakes recorded. Phase data files (arrival times of the earthquake) from the output of SEISAN are input into the HYPOINVERSE-2000 program. Stable locations are usually obtained from about seven to ten arrival times (P- and S-waves combined) for recorded events that are not surrounded by INL seismic stations (Zollweg and Sprenke, 1995). Within the INL network, stable locations can be obtained with a minimum of six arrival times. Because of the density and sensitivity of the INL seismic network, the majority of earthquakes located within the $161-\mathrm{km}$ radius have a minimum of six arrival times.

However, some earthquakes are located with fewer than six arrival times and, thus, their locations are less accurate. Seismic stations from other agencies monitored by the INL provide coverage outside the INL network and phase arrivals from these stations supplement phase data from INL stations in an attempt to reduce location errors. Other notable parameters used in the HYPOINVERSE-2000 program are the starting focal depth, set to $5 \mathrm{~km}$, and the distance cutoff for arrival weighting, set to $50 \mathrm{~km}$.

Four P-wave velocity models are used in the HYPOINVERSE-2000 program depending on the location of the earthquakes (Table 5). The "ESRP" velocity model is used for locating earthquakes that occur within the ESRP and including the mountainous terrain along the Idaho-Wyoming border and southeast Idaho (Olsen et al., 1979; Sparlin et al., 1979; Braile and Smith, 1979; and Ackerman, 1979). The "INL ESRP" velocity model is used to locate earthquakes that occur on the ESRP and are near or within the INL Site boundaries. This model was developed from Sparlin et al. (1982) and Braile et al. (1982) and checked with respect to a few microearthquakes located within the ESRP (Jackson et al., 1989). The "BPEAK" velocity model is used for locating earthquakes that occur in the Borah Peak aftershock area and the mountainous terrain northwest of the Plain (Richins et al., 1987). Finally, the "SMT" velocity model is used to locate earthquake in southwestern Montana (Stickney, 1997). For all velocity models, a P-wave velocity to S-wave velocity ratio of 1.75 is used (Bones, 1978; Greensfelder and Kovach, 1982; and Richins et al., 1987).

\subsection{Magnitude Calculations}

In SEISAN, magnitudes are determined using two methods 1) coda magnitudes using signal duration of digital seismograms and 2) local magnitudes using amplitudes from digital seismograms. A 
coda magnitude $\left(\mathrm{M}_{\mathrm{c}}\right)$ is calculated for an earthquake using several signal durations measured from the seismograms of different seismic stations. A local magnitude $\left(\mathrm{M}_{\mathrm{L}}\right)$ is calculated using the largest peak-to-peak trace amplitude measured from digital waveforms and the Richter magnitude equation. If a magnitude cannot be determined for a local earthquake, then magnitudes determined by other seismic networks may be used including, for example, the University of Utah, Montana Bureau of Mines and Geology, NEIC, Boise State University, and the U.S. Bureau of Reclamation. The summary list of earthquakes in Appendix D lists the type of magnitude calculated and what institution reported the magnitude.

\subsubsection{Coda Magnitudes}

A coda magnitude is determined by measuring the duration of an earthquake's seismic waves as identified on a vertical component seismogram in SEISAN. In SEISAN when the P-wave arrival time is selected, the earthquake's signal duration can be automatically selected by SEISAN or manually selected by a seismologist at INL. The duration is measured at the start of the earthquake signature (P-wave arrival) to the end of the coda, where the signal fades into the background noise of the trace. The durations are measured for each station where the earthquake's signal can be clearly identified. The following expression from Arabasz et al. (1979) is used to calculate the coda magnitude for each seismic station's duration measured:

$\mathrm{M}_{\mathrm{c}}=-3.13+2.74 \log \tau+0.0012 \Delta$

Where:

$\tau=$ Total signal duration recorded at the station in seconds;

$\Delta=$ Epicentral distance from the station in $\mathrm{km}$.

The final coda magnitude is determined from the mean of coda magnitudes calculated for each station. The HYPOINVERSE-2000 program uses Equation (1) to estimate the mean coda magnitude along with the location.

\subsubsection{Local Magnitudes}

A local magnitude is determined by measuring the amplitudes of a synthetic Wood-Anderson seismogram digitally for the horizontal components generated in SEISAN. SEISAN allows the seismologist to generate synthetic Wood-Anderson seismograms from shear waves recorded on the horizontal components of accelerometers and seismometers at INL seismic stations. SEISAN calculates synthetic Wood-Anderson seismograms at a magnification of 2800 using the instrument response information for accelerometers and seismometers contained in Appendix C.

For each horizontal component at a station and for multiple stations, the seismologist manually measure or allows SEISAN to automatically measure the largest peak-to-peak amplitude (or A) in millimeters from the synthetic Wood-Anderson seismogram. Once measured, the local magnitude is calculated for each component using the Richter magnitude scale. Richter (1958) defined the local magnitude scale from the following equation:

$\mathrm{M}_{\mathrm{L}}=\log \mathrm{A}-\log \mathrm{A}_{\mathrm{o}}$

Where: 
$\mathrm{A}=$ Recorded maximum trace amplitude from the zero-line measured in millimeters on a standard, Wood-Anderson seismogram;

$\mathrm{A}_{\mathrm{o}}=$ Maximum trace amplitude from the zero-line in millimeters for a selected standard earthquake.

The Richter magnitude scale was developed for a standard earthquake of magnitude 3.0 at $100 \mathrm{~km}$ for $\mathrm{A}_{\mathrm{o}}$ $=0.001 \mathrm{~mm}$ and amplitude of $1.0 \mathrm{~mm}$ measured on the standard seismogram. Dr. Richter constructed a table of magnitudes based on distance and $-\log A_{o}$ for maximum trace amplitudes recorded on the standard Wood-Anderson seismogram.

SEISAN has a program that uses equation [2] and measured amplitude of each synthetic WoodAnderson horizontal seismogram to calculate local magnitude. SEISAN uses the distance of the seismic station from the earthquake's epicenter and one-half the peak-to-peak amplitude to determine local magnitude using Richter's table. Typically, the earthquake is located using the HYPOINVERSE-2000 program first to estimate distances from the epicenter to seismic stations, then amplitudes are measured.

\subsection{Peak Accelerations}

Peak horizontal and vertical accelerations are determined from accelerograms using the SEISAN program. SEISAN displays the horizontal and vertical accelerograms for some free-field SMAs located at the INL and accelerometers co-located with the seismic stations. The SEISAN program allows the user to correct the accelerograms by removing the instrument responses listed in Appendices B and C. A separate program is used to measure the largest zero-to-peak acceleration amplitude from the corrected acceleration time history.

\subsection{Location and Depth Quality}

Comparisons between earthquake locations determined by the INL and locations determined by other temporary networks or NEIC have been used to approximate locations errors of earthquake epicenters (Jackson et al., 1993a). This method is very general and yields an approximation of the quality of the INL earthquake locations. Zollweg and Sprenke (1995) evaluated the parameters chosen for the HYPOINVERSE-2000 program used by INL and the locations produced for the INL station geometry. They determined that the parameters chosen yield good location results despite the poor coverage in azimuth of earthquakes outside the network. An evaluation of the difference between actual and computed locations showed that HYPOINVERSE-2000 location error was less than $0.25 \mathrm{~km}$ for test events located by the INL seismic stations. A more detailed discussion of location uncertainty is in Section A-5 (Appendix A).

The HYPOINVERSE-2000 location program also calculates depth to the hypocenter. Focal depths calculated by this program are not accurate for many of the earthquakes recorded by the INL seismic network for two reasons: 1) the station spacing is usually greater than twice the focal depth of the earthquake recorded; and 2) the earthquake usually occurs outside of the network. To calculate accurate focal depths, the earthquake ideally should occur within the seismic network and at a distance equal to or less than it's focal depth, and/or have S-arrivals from one or more stations within a distance of 1.4 focal depths of the epicenter (Gomberg et al., 1990). Although focal depths are listed in Appendix D, they should be interpreted within the context of the limitations discussed in this section unless otherwise discussed in another section about specific earthquakes. 


\subsection{Data Completeness}

Local earthquakes are easily discriminated from other seismic data such as local mine blasts, air blasts (or sonic booms), and distant (worldwide) and regional earthquakes occurring far outside of the INL seismic network. For example, man-made blasts are easily discriminated from earthquakes on the basis of waveform characteristics, the time the event occurred, and the location and depth of the event. The NEIC earthquake website lists are regularly inspected to confirm consistency with the INL earthquake catalog for magnitudes 2.5 and greater. Typically, local mine operators provide lists of blasting times when requested by INL seismologists.

Detection threshold can provide a measure of completeness for the INL earthquake catalog. It is defined as the magnitude level at which the seismic network will nearly always detect and locate an earthquake. Zollweg and Sprenke (1995) evaluated the detection threshold of the INL seismic network by plotting the cumulative number of earthquakes as a function of magnitude to determine the lowest magnitude point that the curve begins to flatten. Zollweg and Sprenke (1995) determined the detection threshold to be a magnitude 1.3 , anywhere within a $161-\mathrm{km}(100-$ mile) radius around INL. Their conclusion was based on a plot of 1360 earthquakes for an 18-month period. Since the seismic stations are all located within $90 \mathrm{~km}$ of the center of INL, they suggested that the detection threshold is magnitude 0.8 within the network on the ESRP. The analysis of Zollweg and Sprenke (1995) suggests that the INL earthquake catalog is complete for magnitudes above 1.3 within a 161-km (100-mile) radius of INL and may be complete for magnitudes as low as 0.8 within the network. Ongoing hardware and software upgrades of INL seismic instrumentation and for the current DAAS have increased detection sensitivities to nearly magnitude 0.0 , which allow recording of small magnitude microearthquakes within ESRP. 
Table 5. P-wave velocity models used in location programs.

\begin{tabular}{|c|c|c|c|c|}
\hline Velocity Model Code & $\begin{array}{l}\text { Velocity } \\
(\mathrm{km} / \mathrm{sec})\end{array}$ & $\begin{array}{l}\text { Depth to Top of } \\
\text { Layer }(\mathrm{km})\end{array}$ & $\begin{array}{c}\text { Layer Thickness } \\
(\mathrm{km})\end{array}$ & References \\
\hline \multirow[t]{4}{*}{ ESRP } & 4.90 & 0.00 & 2.00 & \multirow{4}{*}{$\begin{array}{l}\text { Olsen et al., 1979; } \\
\text { Sparlin et al., 1979; } \\
\text { Braile \& Smith, 1979; } \\
\text { Ackerman, } 1979 .\end{array}$} \\
\hline & 6.00 & 2.00 & 15.00 & \\
\hline & 6.70 & 17.00 & 23.00 & \\
\hline & 7.90 & 40.00 & Half-space & \\
\hline \multirow[t]{7}{*}{ INL ESRP } & 3.30 & 0.00 & 1.00 & \multirow{7}{*}{$\begin{array}{l}\text { Sparlin et al., 1982; } \\
\text { Braile et al., 1982; } \\
\text { Jackson et al., 1989. }\end{array}$} \\
\hline & 4.90 & 1.00 & 2.00 & \\
\hline & 5.30 & 3.00 & 2.00 & \\
\hline & 6.15 & 5.00 & 2.00 & \\
\hline & 6.53 & 7.00 & 10.00 & \\
\hline & 6.80 & 17.00 & 23.00 & \\
\hline & 8.00 & 40.00 & Half-space & \\
\hline \multirow[t]{5}{*}{ BPEAK } & 4.75 & 0.00 & 1.64 & \multirow[t]{5}{*}{ Richins et al., 1987.} \\
\hline & 5.59 & 1.64 & 5.31 & \\
\hline & 6.16 & 6.95 & 11.05 & \\
\hline & 6.80 & 18.00 & 22.00 & \\
\hline & 8.00 & 40.00 & Half-space & \\
\hline \multirow[t]{4}{*}{ SMT } & 5.52 & 0.00 & 5.86 & \multirow[t]{4}{*}{ Stickney, 1997.} \\
\hline & 6.12 & 5.86 & 12.78 & \\
\hline & 6.74 & 18.64 & 20.05 & \\
\hline & 8.00 & 38.69 & Half-space & \\
\hline
\end{tabular}




\section{2012 Earthquake Activity}

During 2012, INL recorded 17,329 independent triggers from earthquakes and blasts that occurred in the local region, in the western United States, and worldwide. Within the local region, INL located 1,460 earthquakes and man-made blasts outside and within a 161-km (or 100-mile) radius of INL. Near and within the $161-\mathrm{km}$ radius of INL, 16 earthquakes had small to moderate size magnitudes (M) from 3.0 to 3.6. Of the 695 earthquakes that occurred within the $161-\mathrm{km}$ radius of INL, 11 occurred within the ESRP.

\subsection{Regional Earthquake Activity}

Fourteen earthquakes of $\mathrm{M} \geq 3.0$ earthquakes occurred outside of the 161-km radius around INL in central Idaho, southern Montana, western Wyoming, southeastern Idaho, and northern Utah (Figure 5). Three events occurred in central Idaho. On August 15, 2012, an $\mathrm{M}_{\mathrm{L}} 3.0$ earthquake occurred southeast of Stanley, Idaho. Two earthquakes of $M_{c} 3.0$ and $M_{c} 3.1$ occurred on July 25, 2012 and August 26, 2012, respectively, west of Challis, Idaho. None of these earthquakes were reported as felt by local residents. One event occurred near Dillon, Montana (Figure 5): on September 5, 2012, an earthquake of $\mathrm{M}_{\mathrm{L}} 3.3$ occurred and was felt by local residents (Section A-6; Appendix A).

Throughout 2012, the majority of earthquakes having magnitudes $>3.0$ were scattered along the Idaho-Wyoming border (Figure 5). Five earthquakes of magnitudes from 3.0 to 3.5 occurred near the Yellowstone Caldera. Three of these events occurred on October 15, 2012 within 2 hrs of each other. They were all located in the same vicinity on the Idaho-Wyoming border southeast of Island Park, Idaho (Figure 5). The magnitudes included one $\mathrm{M}_{\mathrm{L}} 3.1$ and two $\mathrm{M}_{\mathrm{L}} 3.0$ events, none of which were felt by local residents. Two other larger magnitude earthquakes, $\mathrm{M}_{\mathrm{L}} 3.2$ and $\mathrm{M}_{\mathrm{L}}$ 3.5, occurred on August 7, 2012 and September 5, 2012, respectively. These two events were located northeast of Island Park near Hebgen Lake, Montana (Figure 5), and both were felt by local residents (Section A-6; Appendix A).

Farther south along the Idaho-Wyoming border, four earthquakes occurred near Afton, Wyoming outside the 161-km radius of INL. Two earthquakes of $\mathrm{M}_{\mathrm{L}} 3.0$ on January 8, 2012 and moment magnitude (Mw) 3.6 on May 10, 2012 were located northeast of Afton in Wyoming (Figure 5). Neither event was reported felt by local residents. The other two earthquakes, an $\mathrm{M}_{\mathrm{L}} 3.0$ and $\mathrm{M}_{\mathrm{L}} 3.4$, were located southeast of Afton. The $\mathrm{M}_{\mathrm{L}} 3.0$ event occurred on February 28, 2012 and was not reported felt by local residents. The $\mathrm{M}_{\mathrm{L}} 3.4$ event occurred on January 5, 2012 and was reported felt by local residents (Section A-6; Appendix A). Near the Utah-Idaho border south of Malad City, Idaho in northern Utah, one earthquake of $\mathrm{M}_{\mathrm{L}} 3.5$ occurred on July 13, 2012 and was also reported felt by local residents (Section A-6; Appendix A).

\subsection{Earthquake Activity within 161-km Radius of INL}

During 2012, 695 earthquakes occurred within 161-km radius of INL; two of these earthquakes exceeded M 3. Earthquakes occurred in southeastern Idaho, along the Idaho-Wyoming border near Jackson, Wyoming, near Island Park, Idaho, in southwestern Montana, northwest of the INL, and within the ESRP (Figure 6). The two largest magnitude earthquakes, $M_{c} 3.0$ on March 9, 2012 and $M_{L} 3.2$ on April 4, 2012, were located northeast of Soda Springs, Idaho (Figure 5). Neither event was felt by local residents. Although 161 earthquakes occurred in the vicinity of the $\mathrm{M}_{\mathrm{c}} 3.0$ and $\mathrm{M}_{\mathrm{L}} 3.2$ events, they do not appear to be related to swarm activity or to either event. 216 small magnitude earthquakes occurred west of Jackson, Wyoming along the Idaho-Wyoming border. A small swarm of 39 earthquakes occurred from April to July near Driggs with four of the largest magnitudes including $\mathrm{M}_{\mathrm{c}}$ 2.0-2.5 earthquakes. Although 
only seven earthquakes are shown in Figure 5 at the Idaho-Wyoming border near Island Park, Idaho, 100 's of earthquakes occurred to the west in the Yellowstone Caldera.

156 earthquakes were located along the Idaho-Montana border (Figure 5). Although some events appear in clusters in southern Montana, very few are associated with swarm activity. Thirteen earthquakes have magnitudes from $\mathrm{M}_{\mathrm{c}} 2.0$ to 2.8, which are located in southern Montana and just over the border in Idaho. Further west in central Idaho, earthquakes occurred near Challis, Idaho and Stanley, Idaho. Earthquakes in Figure 5 show clusters of epicenters near Challis and to the southeast of the Challis. A small cluster of earthquakes are shown south of Stanley. Other earthquakes are scattered over the region located northeast and south of Challis. Nineteen of the 105 events in this region have magnitudes from $\mathrm{M}_{\mathrm{c}}$ 2.0 to 2.6 .

\subsection{Earthquakes within the Eastern Snake River Plain}

Eleven microearthquakes were located within the ESRP during 2012 (Figure 6). A microearthquake of $\mathrm{M}_{\mathrm{c}} 1.3$ occurred on January 2, 2012 and was located near the eastern physiographic boundary of the ESRP northeast of Pocatello, Idaho. Four microearthquakes were located west of Idaho Falls. The first event of $M_{c} 1.4$ occurred on July 31, 2012 and three other events of $M_{L} \leq 1.0$ occurred on August 4, 2012 within 30 minutes of each other. All events occurred between 11.5 and $12.9 \mathrm{~km}$ depth, and their waveforms appear tectonic in character. Two earthquakes were located with in the INL boundary near locations where events have been detected historically. The first event of $\mathrm{M}_{\mathrm{L}} 0.3$ is located near the western boundary of INL. It occurred on August 17, 2012 and has a focal depth of $9.6 \mathrm{~km}$. The second event of $\mathrm{M}_{\mathrm{L}} 0.5$ is located near the southeast boundary of INL. It occurred on October 8, 2012 and has a focal depth of $2.4 \mathrm{~km}$. The waveforms of each event appear tectonic in character.

Four microearthquakes occurred near the northern end of the Great Rift volcanic rift zone, which includes Craters of the Moon National Monument and Preserve (COM) (Figure 6). All of the events are located within and near the boundary of the COM (Figure 7). The first event of $\mathrm{M}_{\mathrm{L}} 1.6$ occurred on February 2, 2012. A second event of $M_{L} 1.6$ occurred on July 28, 2012. The third and fourth events of $M_{L}$ 1.0 and $\mathrm{M}_{\mathrm{L}} 1.7$ occurred on September 22, 2012. These two events were the only ones that could be located since they occurred during 3 minute multiple-event sequence of four or five events. Three of the events have uncharacteristic deep depths of 20.5, 21.5, and $24.0 \mathrm{~km}$ (Figure 7). Their waveforms, particularly for the multiple events, have low-frequency characteristics suggesting the events may be volcanic related. They are a continuation of the on-going, low-rate micro-seismicity at COM that began in 2007 (Carpenter and Payne, 2009).

\section{5. $1972-2012$ Earthquake Activity}

The earthquakes in 2012 were located in areas around and within the ESRP that have been active in previous years. Figure 8 shows that the majority of 2012 earthquakes occur in the Basin and Range Province regions surrounding the ESRP. Even though 81 microearthquakes $(M \leq 2.2)$ have occurred within the ESRP, monitoring by the INL seismic network indicates that at present the ESRP is relatively seismically inactive when compared to surrounding Basin and Range Province (see also Jackson et al., 1993b). Ongoing activity of 29 events (2007-2012) within and near the Great Rift suggests possible association with volcanic processes. Nearly 2,200 years ago, the entire $80-\mathrm{km}$ length of the Great Rift was volcanically active (Kuntz et al., 2002). 


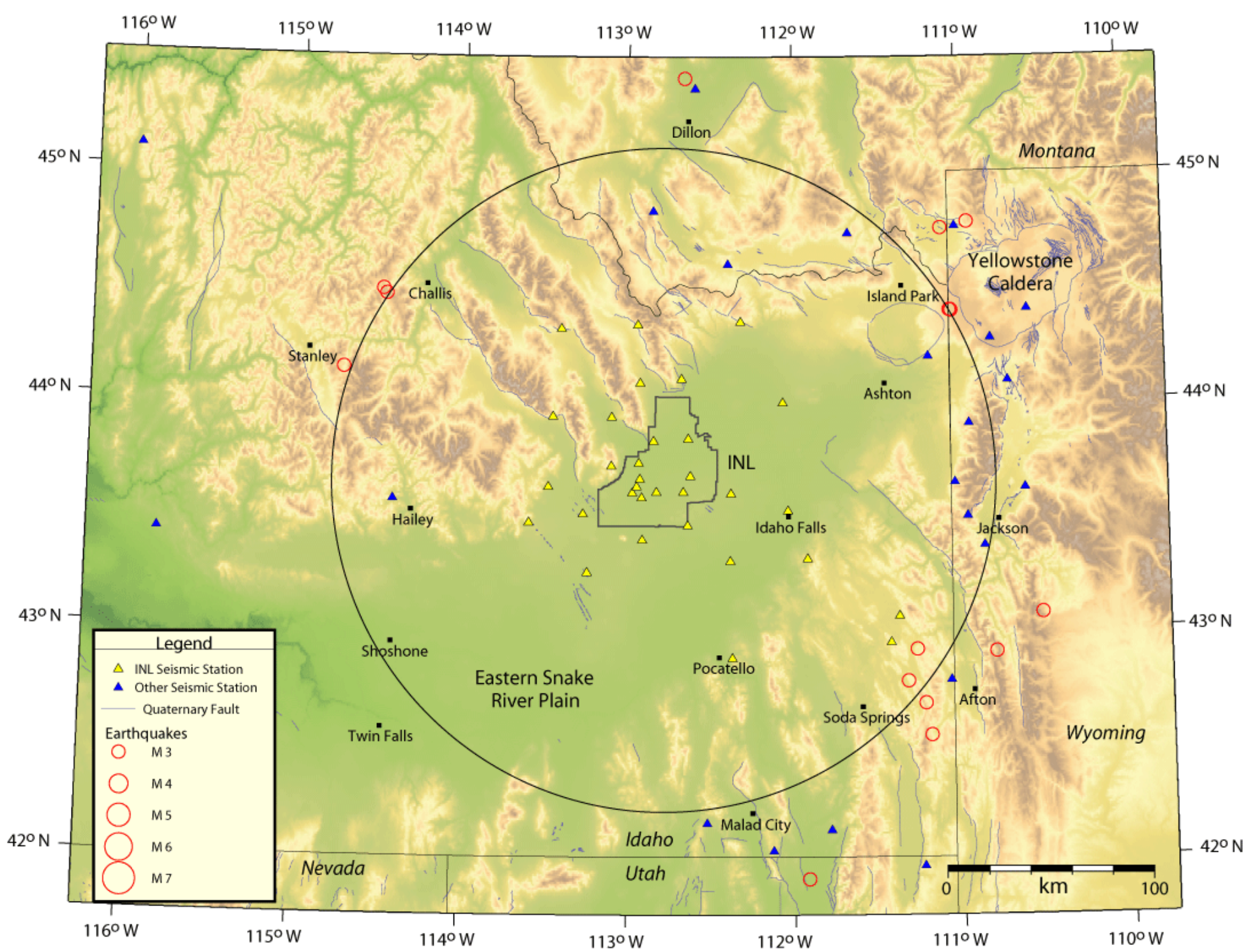

Figure 5. Map of epicenters of earthquakes for magnitudes greater than 3.0 during 2012. 


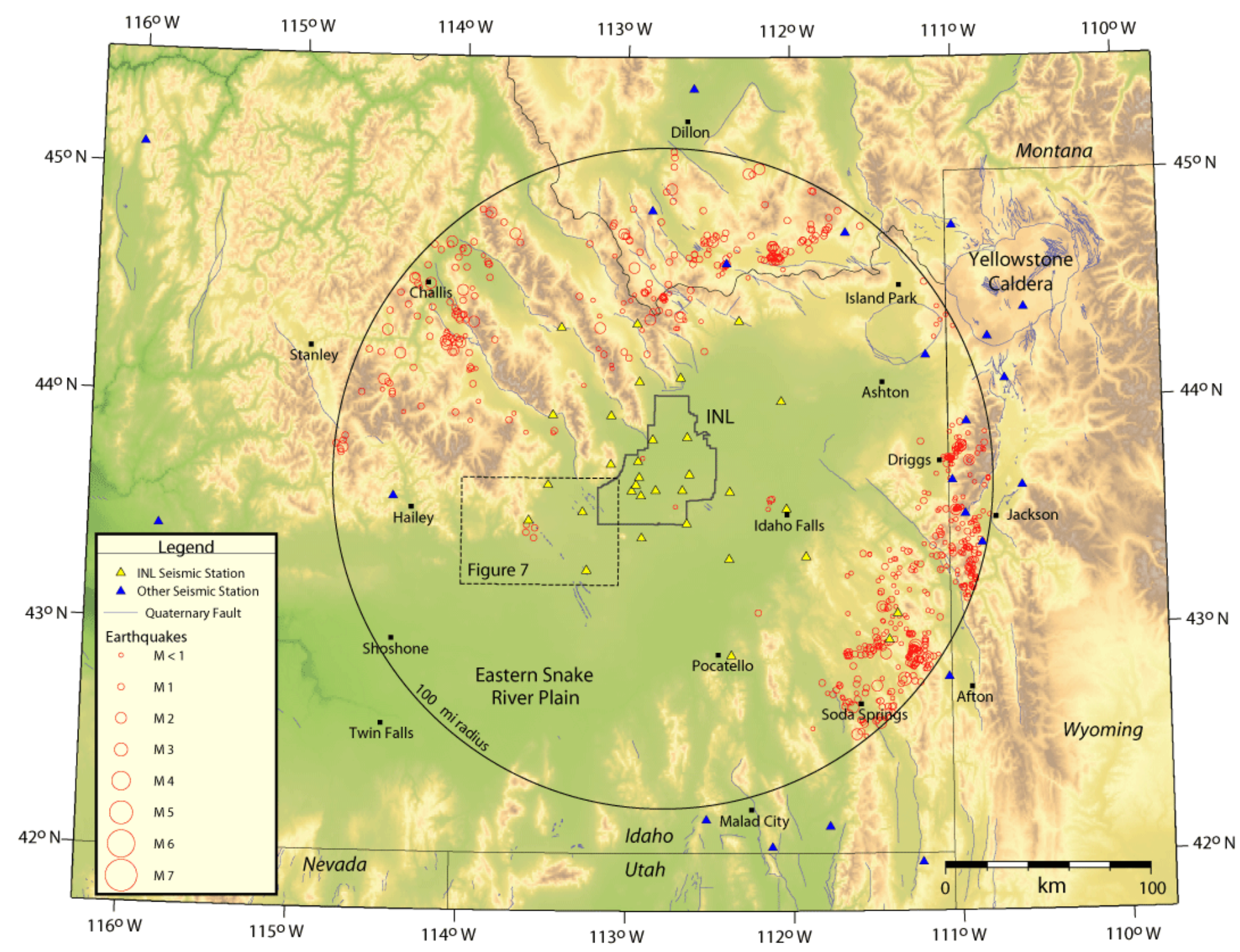

Figure 6. Map of epicenters of earthquakes within the 161-km radius around the INL from January 1, 2012 to December 31, 2012. Dashed box shows the region for Figure 7. 


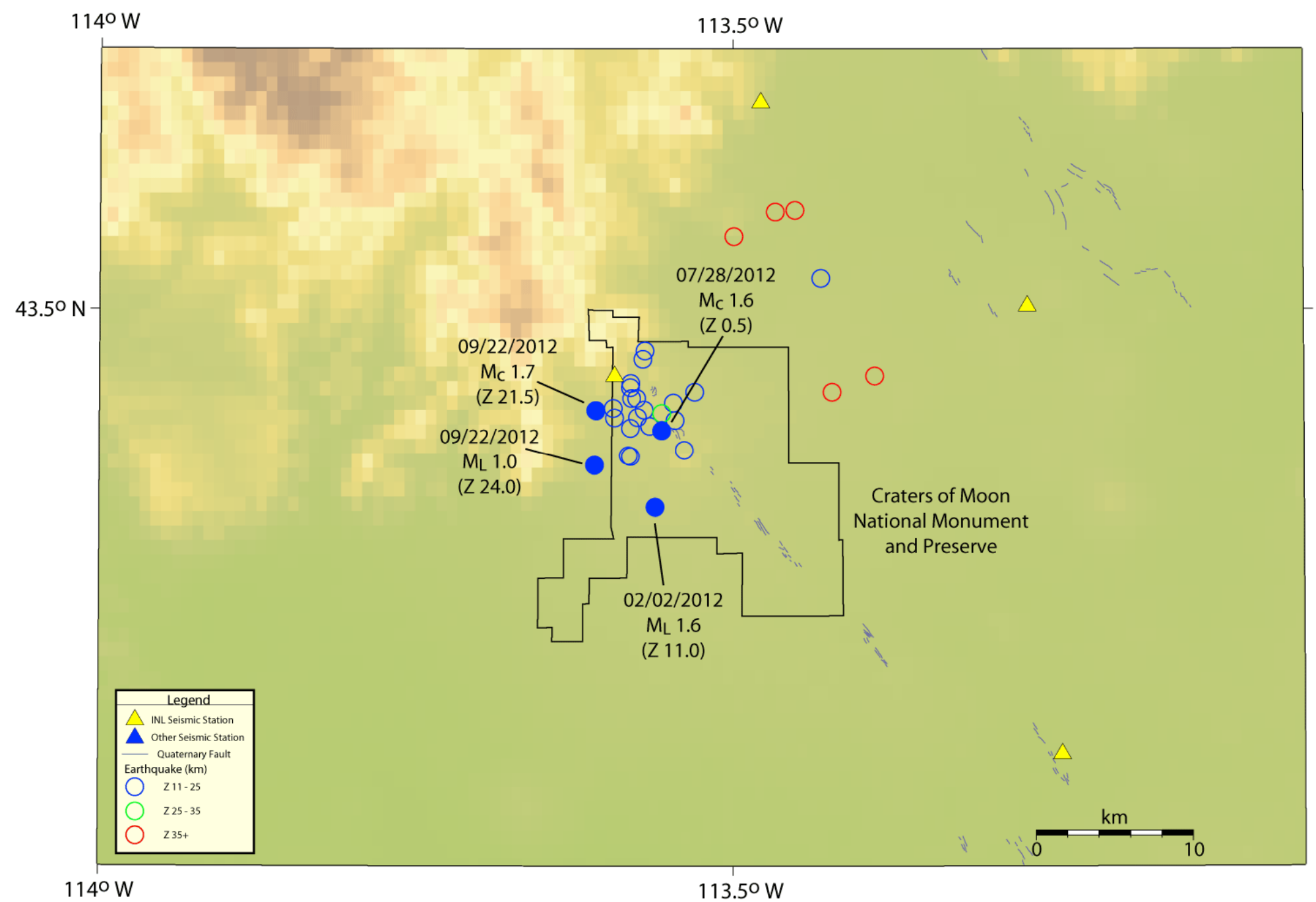

Figure 7. Map shows epicenters of earthquakes (colored by focal depth) at Craters of the Moon National Monument and Preserve (black polygon) from 1999 to 2012 (Carpenter and Payne 2009). The four 2012 earthquakes (solid blue circles) are shown with dates, magnitude, and depth (Z). 


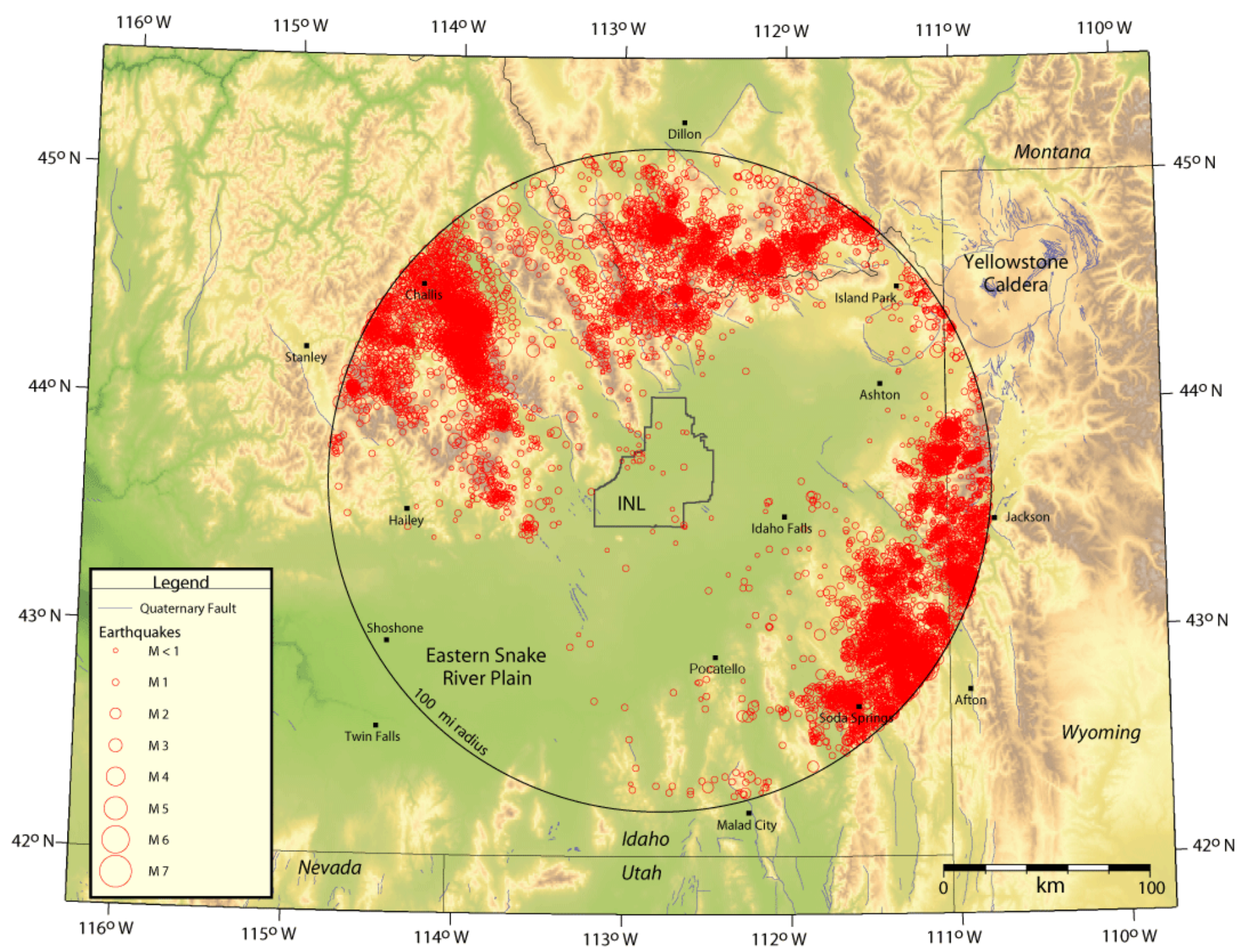

Figure 8. Map of epicenters of earthquakes from 1972 to 2012 within the 161-km (100 mile) radius around the INL. 


\section{References}

Ackerman, H. D. (1979). Velocity Structure to 3000-Meter Depth at the Idaho National Engineering Laboratory, Eastern Snake River Plain (abstract), EOS Transactions, American Geophysical Union, v. 60 , no. 46 , p. 942.

Arabasz, W. J., R. B. Smith, and W. D. Richins (1979). Earthquake Studies Along the Wasatch Front, Utah: Network Monitoring, Seismicity, and Seismic Hazards, Earthquake Studies in Utah - 1850 to 1978, W. J. Arabasz, R. B. Smith, and W. D. Richins, Editors, published by the University of Utah, p. 253-286.

Bones, D. B. (1978). Seismicity of the Intermountain Seismic Belt in Southeastern Idaho and Western Wyoming, and Tectonic Implications, unpublished M. S. Thesis, University of Utah.

Braile, L. W. and R. B. Smith (1979). The Structure of the Crust in the Yellowstone-Snake River Plain Area and Adjacent Provinces and Implications for Crustal Evolution (abstract), EOS Transactions, American Geophysical Union, v. 60, no. 46, p. 941.

Braile, L. W., R. B. Smith, J. Ansorge, M. R. Baker, M. A. Sparlin, C. Prodehl, M. M. Schilly, J. H. Healy, ST. Mueller, and K. H. Olsen (1982). The Yellowstone-Snake River Plain Seismic Profiling Experiment: Crustal Structure of the Eastern Snake River Plain, Journal of Geophysical Research, v. 87 , no. B4, p. 2597-2609.

Carpenter, N. S. and S. J. Payne (2009). Deep, Long-Period Earthquakes in and around Craters of the Moon National Monument, Idaho, Seismological Research Letters, v. 80, p. 350.

DOE (2012). Facility Safety, U.S. Department of Energy, DOE Order 420.1C.

EarthScope (2007). http://www.earthscope.org/observatories/usarray.

Gomberg, J. S., K. M. Shedlock, and S. W. Roecker (1990). The effect of S-wave arrival times on the accuracy of hypocenter estimation, Bulletin of the Seismological Society of America, v. 80, p. $1605-1628$.

Greensfelder, R. W. and R. L. Kovach (1982). Shear Wave Velocities and Crustal Structure of the Eastern Snake River Plain, Idaho, Journal of Geophysical Research, v. 87, no. B4, p. 2643-2653.

Jackson, S. M., D. M. Anderson, G. S. Carpenter, H. K. Gilbert, S. M. Martin, and P. J. Permann (1989). The 1988 INEL Microearthquake Survey near the Western Edge of the eastern Snake River Plain, EG\&G Internal Technical Report EGG-BEG-8665, August, 48 p.

Jackson, S. M., G. S. Carpenter, D. M. Anderson, D. L. Scott, J. L. Casper, and R. B. Powell (1993a). INEL Seismograph Stations Annual Report: January 1 - December 31, 1992, EG\&G Internal Technical Report EGG-EELS-004, 114 p.

Jackson, S. M., I. G. Wong, G. S. Carpenter, D. M. Anderson, and S. M. Martin (1993b). Contemporary Seismicity in the eastern Snake River Plain, Idaho based on Microearthquake Monitoring, Bulletin of the Seismological Society of America, v. 83, no. 3, June, p. 680-695.

Klein, F.W. (2002). User's guide to HYPOINVERSE-2000, a Fortran program to solve for earthquake locations and magnitudes, U.S. Geological Survey Open-File Report, 02-171. 
Kuntz, M.A., Anderson, S.R., Champion, D.E., Lanphere, M.A. \& Grunwald, D.J. (2002). Tension cracks, eruptive fissures, dike, and faults related to late Pleistocene - Holocene basaltic volcanism and implications for the distribution of hydraulic conductivity in the eastern Snake River Plain, Idaho, in Link, P.K. and L.L. Mink, eds., Geology, Hydrogeology, and Environmental Remediation: Idaho National Engineering and Environmental Laboratory, Eastern Snake River Plain, Idaho, Geologic Society of America Special Paper, 353, p. 111-133.

Olsen, K. H., E. F. Homuth, J. N. Stewart, R. N. Felch, T. G. Handel, and P. A. Johnson (1979). Upper Crustal Structure Beneath the Eastern Snake River Plain Interpreted from Seismic refraction Measurements Near Big Southern Butte, Idaho (abstract), EOS Transactions American Geophysical Union, v. 60, no. 46, p. 941.

Payne, S. J., R. McCaffrey, and S. A. Kattenhorn (2013). Extension Driven Right-lateral Shear in the Centennial Shear Zone Adjacent to the Eastern Snake River Plain, Idaho, Lithosphere, v. 5, no.4, p. p. 407-419.

Payne, S.J., R. McCaffrey, R.W. King, and S.A. Kattenhorn (2012). An new interpretation of deformation rates in the Snake River Plain and adjacent Basin and Range regions from GPS measurements, Geophysics Journal International, v. 189, p. 101-122, doi: 10.1111/j.1365-246X.2012.05370.x.

Richins, W. D., J. C. Pechmann, R. B. Smith, C. J. Langer, S. K. Goter, J. E. Zollweg, and J. J. King (1987). The 1983 Borah Peak, Idaho Earthquake and Its Aftershocks, Bulletin of the Seismological Society of America, v. 77, no. 3, p. 694-723.

Richter, C. F. (1958). Elementary Seismology, W. H. Freenam and Company, San Francisco, p. 340-342.

Seismic (1993). INEL Seismic Network: Seismic station boreholes, EG\&G Idaho, Inc., Idaho Falls, Idaho Engineering Design File EDF-SEIS-0003, 28 p.

Sparlin M., L. W. Braile, M. R. Baker, and R. B. Smith (1979). Interpretation of Seismic Profiles Across the Eastern Snake River Plain (abstract), EOS Transactions American Geophysical Union, v. 60, no. 46, p. 941.

Sparlin, M. A., L. W. Braile and R. B. Smith (1982). Crustal Structure of the Eastern Snake River Plain Determined from Ray Trace Modeling of Seismic Refraction Data, Journal of Geophysical Research, v. 87, no. B4, p. 2619-2633.

Stickney, M.C. (1997). Seismic source zones in southwest Montana, Montana Bureau of Mines and Geology, Butte, Montana Open-file report 366.

U.S. Geological Survey (2014). “Did You Feel It?” web archives http://earthquake.usgs.gov/earthquakes/dyfi/archives.php, accessed December.

Zollweg, J.E., and K. F. Sprenke (1995). Review of Idaho National Engineering Laboratory Seismographic Networks and Seismic Hazard Program, prepared for the State of Idaho INEL Oversight Program, Technical Report 95-01, 72 p. 


\section{Appendix A}

\section{Seismic Network and Earthquake Information}

\section{A-1. INL Seismic Network History}

The INL seismic network has evolved from a single analog station to its current configuration of 27 digital seismic stations. The INL Seismic Monitoring Program also records data from seismic stations owned and operated by other seismic networks. The INL seismic network began with a single station in 1971 and expanded to three stations by October of 1972. In 1977, the INL began monitoring a station operated by BYU-Idaho in Rexburg, Idaho. The INL installed two additional stations in 1979 and from 1979 to 1985 , the INL monitored earthquake activity using six seismic stations. In 1985, the INL installed a simulated Wood-Anderson system to improve the capabilities of measuring the magnitude of local earthquakes $(3.0 \leq \mathrm{M} \leq 5.0)$. During 1986, the INL began receiving seismic data from a station located in Pocatello, Idaho and operated by the University of Utah in Salt Lake City, Utah. Also in 1986, the INL began receiving data from a station located near Palisades Reservoir, Idaho that is operated by BYUIdaho. A seismic station within the INL boundaries was added to the INL seismic network in 1987.

From 1990 to 1994, INL seismic network underwent a major expansion of seismic stations. During 1990, four seismic stations were installed within the INL boundaries. From 1991 to 1992, thirteen new stations were installed in support of construction and operation of the proposed New Production Reactor at INL. Shallow boreholes $(<20 \mathrm{~m})$ were drilled for seismic stations located within the ESRP. Also, monitoring of BYU-Idaho seismic station near Palisades Reservoir was terminated in 1991 to accommodate the addition of the new INL seismic stations. In 1994, two new INL seismic stations were installed near Gray's Lake, Idaho.

Several changes occurred to seismic stations from 1999 to 2003. During 1999, the INL Howe Scarp, Idaho (HWSI) seismic station was relocated further east to a new location now referred to as the Howe Fault, Idaho or HWFI because of a lawsuit filed against the Bureau of Land Management. With the implementation of the "EARTHWORM" computer software in 2000, up to 14 stations from several nearby networks were being recorded in real-time along with the INL seismic stations. During 2001-2003, analog seismic instruments at all INL seismic stations were replaced with digital instruments. In 2003, the University of Utah transferred ownership of the Pocatello, Idaho (PTI) seismic station to the INL Seismic Monitoring Program at which time a digital seismic station was installed. With addition of the PTI station, INL has operated 27 seismic stations from 2003 through 2012.

\section{A-2. INL Strong Motion Accelerograph History}

The INL accelerograph network, which began by installing eleven SMAs in critical INL facilities, consists of SMAs installed in buildings at INL facility areas and at free-field sites for both rock and soil conditions. The original network was composed of three SMAs installed within buildings at the Idaho Nuclear Technology and Engineering Center (INTEC) (formerly referred to as Idaho Chemical Processing Plant - ICPP), two located within the Materials and Fuels Complex (MFC) facilities (formerly referred to as Argonne National Laboratory - ANL), three installed within the Power Burst Facility (PBF), two located within buildings at the Advanced Test Reactor (ATR) (formerly referred to as Test Reactor Area - TRA), and one located at the Old Fire Station (OFS). From 1978 to 1979, four SMAs were installed at Test Area North (TAN) within the Containment Test facility (formerly referred to as Loss of Fluid Test - LOFT facility). Just prior to the October 1983 surface-wave magnitude $\left(\mathrm{M}_{\mathrm{s}}\right) 7.3$ Borah Peak, Idaho earthquake, one SMA was installed at the IRC, which is now part of the REC in Idaho Falls, Idaho. Following the 1983 earthquake, two SMAs were installed within buildings at the Naval 
Reactor Facility (NRF). In 1984, two additional SMAs were placed within buildings at INTEC. During 1990, one SMA was installed at the Central Facilities Area (CFA). A digital SMA was co-located with an analog SMA at MFC in 1993. In 1996, two free-field SMA sites were installed, one at NRF and the other at PBF. In 1997, one SMA was installed as a free-field site at the Radioactive Waste Management Complex (RWMC). In 2003, the SMAs were upgraded to digital NetDAS SMAs. At that time, one NetDAS digital SMA replaced two SMAs co-located at Building ANL-767 (Kinemetrics analog SMA-1 and digital SSA-2 accelerographs). The SMA on the crane beam at PBF-620 was not upgraded, but removed due to decommissioning activities.

Over the years, several SMAs have been relocated because buildings have been decommissioned and demolished. In 1995, the SMA at OFS was moved to a storage building directly behind the fire station because the fire station was decommissioned. In 1997, when the storage building was demolished, this SMA was relocated to the Experimental Field Station (EFS). In 1996, the Containment Test facilities, or LOFT facilities, were decommissioned. Three of the SMAs from LOFT were moved to the TAN Hot Shop and one was placed at the TAN Air Monitoring building. In 1997, the SMA at CFA was relocated to CFA-1607 Refueling Building. In 2004, the TAN Air Monitoring building was demolished so the SMA was removed and was reinstalled in 2005 as a free-field near the TAN Hot Shop. In 2004, the PBF building was demolished and the three SMAs were removed. The SMAs were reinstalled in 2005 as freefield sites near PBF and RWMC. In 2006, four SMAs at TAN were removed due to demolition of the TAN Hot Shop. In 2007, two of these SMAs were reinstalled; one was installed at the Special Manufacturing Complex (SMC) and the other at a free-field site east of SMC. In 2008, two SMAs were removed as a result of building demolition activities. One SMA at INTEC in building CPP-668 and one at ATR were removed. These SMAs were reinstalled at TAN and the New Production Reactor seismic station, NPRI. During 2009, two SMAs were removed at INTEC from building CPP-601 as a result of building demolition activities. In 2010, the SMA at CFA, called EFSF, was uninstalled, moved to the nearby pump house, and renamed to PHFF.

Three-component accelerometers and SMAs were added to some of the seismic stations. In 2002, accelerometers were added to four seismic stations: Bear Canyon (BCYI), Gray's Range (GRRI), NPRI, and HWFI. In 2003, accelerometers were added to seismic stations Telchick Spring, Idaho (TCSI), Split Crater (SPCI), and PTI. In 2004, the accelerometer at TCSI was uninstalled. In 2008, a free-field SMA was installed at the Craters of the Moon (COMI) seismic station. During 2012, the INL Accelerograph Network operated up to 20 SMAs within or near INL Site facility areas, two sites outside of the INL boundary (IRC and COMI), and five three-component accelerometers installed at seismic stations for a total of 27 sites with acceleration recording capabilities.

\section{A-3. Evolution of INL Seismic Data Acquisition and Analysis Computer System}

INL began recording earthquake data on the DAAS June 8, 1991 using the U. S. Geological Survey (USGS) CUSP processing software. Since 2001, significant upgrades have been made to the DAAS as a result of computer hardware and software advances. The USGS's CUSP data acquisition and analysis software supported use of the TIMIT program, which was used to analyze earthquake data from June 1991 to November 2002. The USGS CUSP and TIMT software packages were replaced in 2002 with the earthquake analysis program SEISAN (developed by the University of Bergen, Norway) and the USGS EARTHWORM processing software in 2003. As of December 2002, earthquake data are analyzed using the SEISAN program and is still in use today. Use of the SEISAN and EARTHWORM programs facilitate the upgrades of seismic stations and SMAs to currently available digital data loggers and sensors, which enables concurrent waveform analyses of both velocity and acceleration data. 


\section{A-4. INL Seismic Network Telemetry}

Digital radios, Internet, or DSL links transmit seismic data from INL seismic stations and free-field SMAs to the IRC. Some seismic stations are used as relay links to transmit several seismic stations to a DSL drop point or directly to the IRC. Figure A-1 shows the telemetry configuration during 2012.

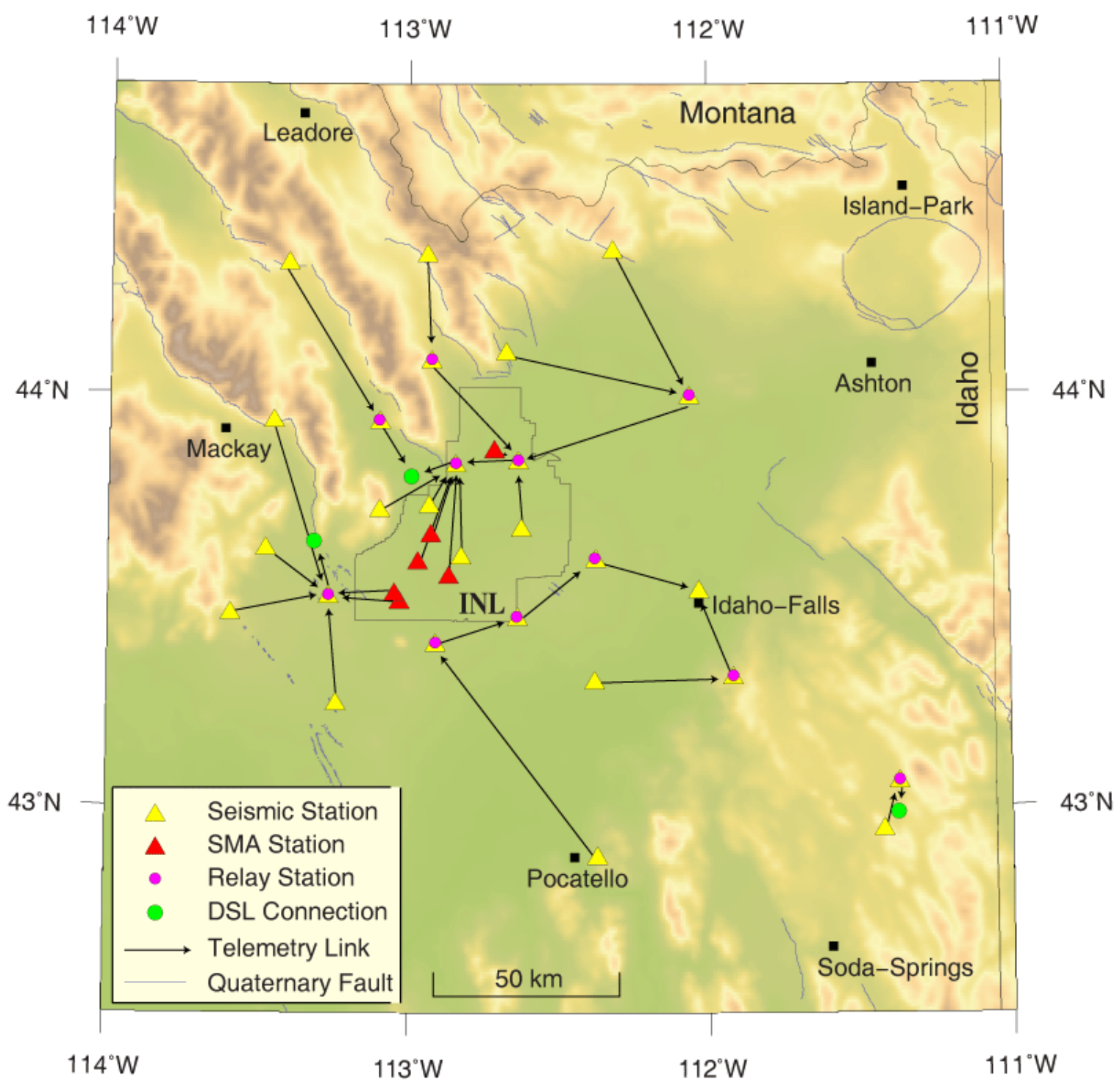

Figure A-1. Telemetry configuration of INL seismic stations and free-field SMAs during 2012. 


\section{A-5. 1995 Evaluation of INL Seismic Network Location Quality}

In 1995, the State of Idaho at that time requested that Zollweg and Sprenke (1995) perform an independent assessment of the INL Seismic Monitoring Program. Zollweg and Sprenke (1995) evaluated the location accuracy of the INL seismic network by two methods: 1) directly comparing INL locations to well-located earthquakes; and 2) indirectly by evaluating the network bias or non-random error through varying independent permutations (or combinations) of recording stations.

For the first method, twenty-two earthquakes having high-quality locations determined from a temporary seismic network installed near Challis, Idaho from July 1, 1992 to July 12, 1992 (by Boise State University) were compared to INL locations for these earthquakes. The earthquakes were located about $120 \mathrm{~km}$ from the center of INL, had varying magnitudes ranging from 1.9 to 4.5 , and had absolute errors less than $1 \mathrm{~km}$. The epicenters determined by INL seismic stations for these events differed by 1.6 to $11.5 \mathrm{~km}$ with an average of $7.1 \mathrm{~km}$. The differences in locations were dependent on magnitude, with the smaller magnitude earthquakes tending to have greater differences in locations (Zollweg and Sprenke, 1995). These results are similar to the earlier estimates of an error radius of $5 \mathrm{~km}$ for a comparison to high-quality locations of the aftershocks from the surface-wave magnitude $\left(\mathrm{M}_{\mathrm{s}}\right) 7.3$ October 28, 1983 earthquake (Jackson et al., 1993a). However it is noted that this estimate for an error radius was based on having five stations in the INL seismic network at that time. The closest station to the aftershocks was at a distance of $50 \mathrm{~km}$ or more.

The second method used by Zollweg and Sprenke (1995) evaluates the network bias. Unless all earthquakes are located using exactly the same groups of stations and phases (P-and S-wave arrivals), the relative locations will be affected by a non-random error or network bias. The network bias is important for the smaller earthquakes that make up the majority of the events in a catalog since fewer stations usually record smaller earthquakes. Five earthquakes located northwest of the INL seismic network and ranging in magnitude from 1.8 to 3.8 were used in the analysis. Because INL operated 26 seismic stations at the time of the assessment, there were millions of possible combinations of recording stations. Zollweg and Sprenke (1995) chose to vary the combination of the ten most influential phase arrivals for the permutation analysis. The locations for most of the permutations clustered about radii ranging from 6.5 to $11 \mathrm{~km}$. For the magnitude 3.8 earthquake, $8 \%$ of the permutations resulted in a linear band extending 100 $\mathrm{km}$. Zollweg and Sprenke (1995) suggested that earthquakes located with fewer S-wave arrival times have less well-constrained locations. Some of the larger earthquakes, like the magnitude 3.8 earthquake, have fewer S-wave arrival times because the signals saturate the instrumentation and onset of the S- wave is indistinguishable from the $\mathrm{P}$-waves. Earthquakes with more than three $\mathrm{S}$-wave-arrival times resulted in better-constrained locations. 


\section{A-6. Earthquake Intensity Maps}

The U.S. Geological Survey with the cooperation of various regional seismic networks provide a web page where people who experience an earthquake can go online and share information about its effects to help create a map of shaking intensities and damage. The "Community Internet Intensity Maps" contribute toward the quick assessment of the scope of an earthquake emergency and provide valuable data for earthquake research (U.S. Geological Survey, 2014). The Web site is called "Did You Feel It?" and is the place where a person can enter their ZIP Code and answer a list of questions about what they felt and what damage occurred. Figures A-2, A-3, and A-4 show the responses from local residents and their reported effects for the felt earthquakes discussed in Section 4.1.

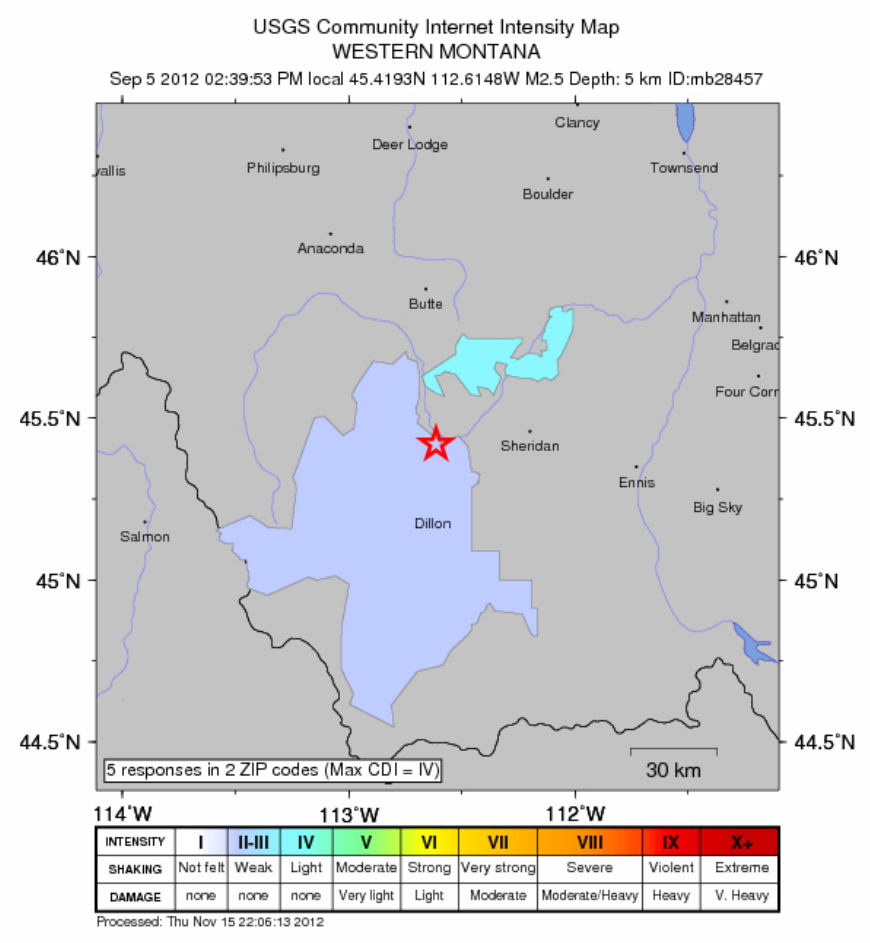

Figure A-2. Earthquake intensity map for the September 5, 2012 (20:39 UTC) $\mathrm{M}_{\mathrm{L}} 3.3$ earthquake located north of Dillon, Montana (U.S. Geological Survey, 2014). 
a)

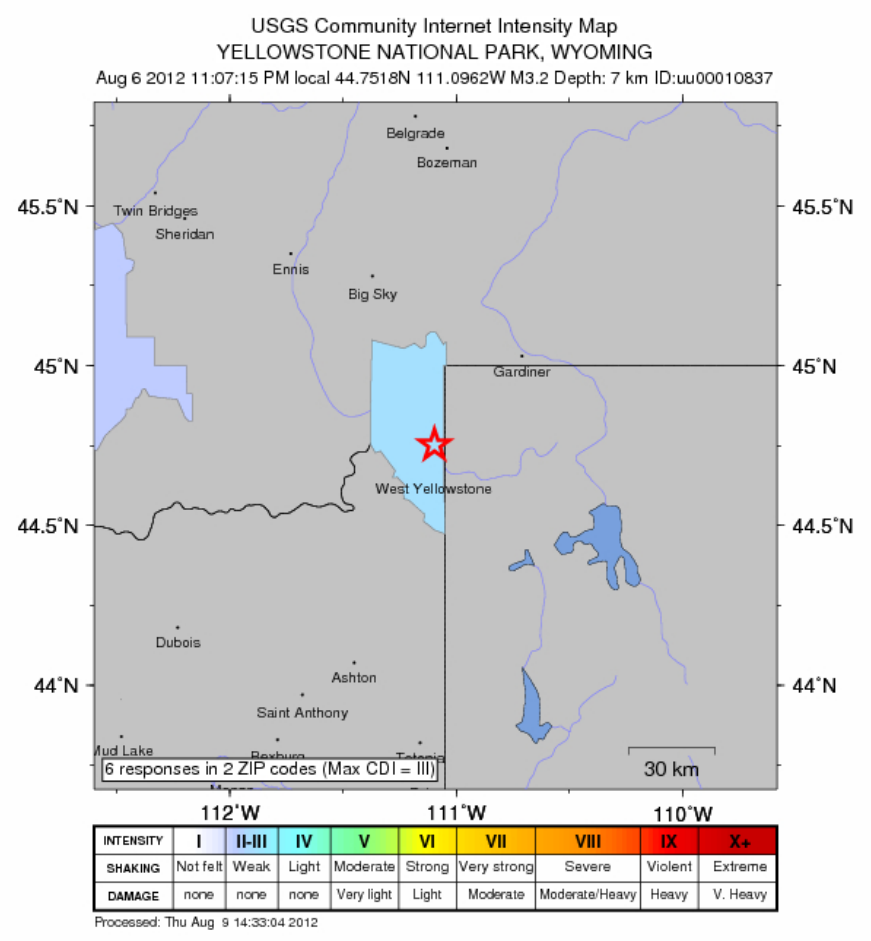

b)

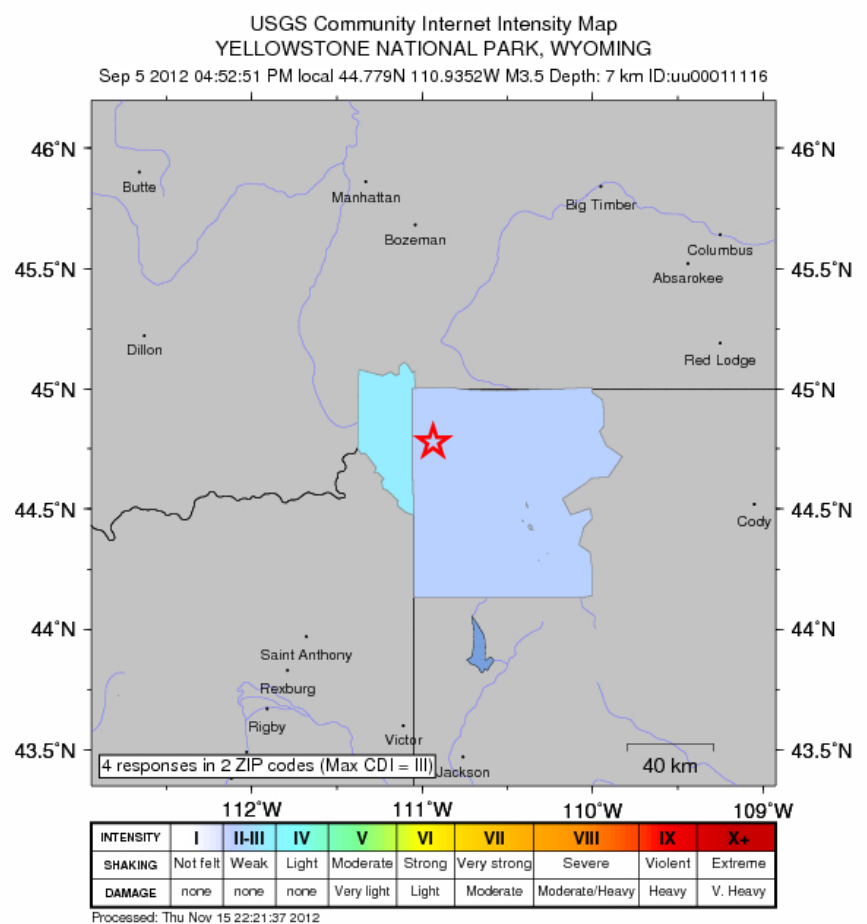

Figure A-3. Earthquake intensity maps for the: a) August 7, 2012 (05:07 UTC) $\mathrm{M}_{\mathrm{L}} 3.2$ earthquake; and b) September 5, 2012 (05:52 UTC) $\mathrm{M}_{\mathrm{L}} 3.5$ earthquake located near Yellowstone National Park, Wyoming (U.S. Geological Survey, 2014). 
a)

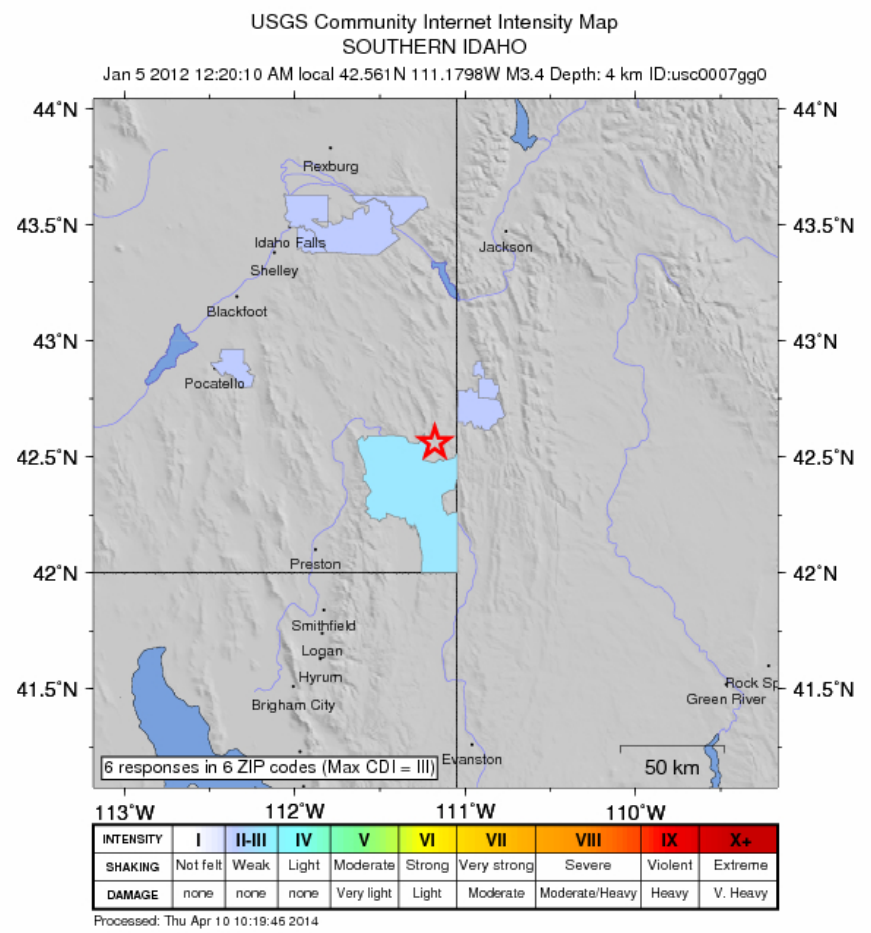

b)

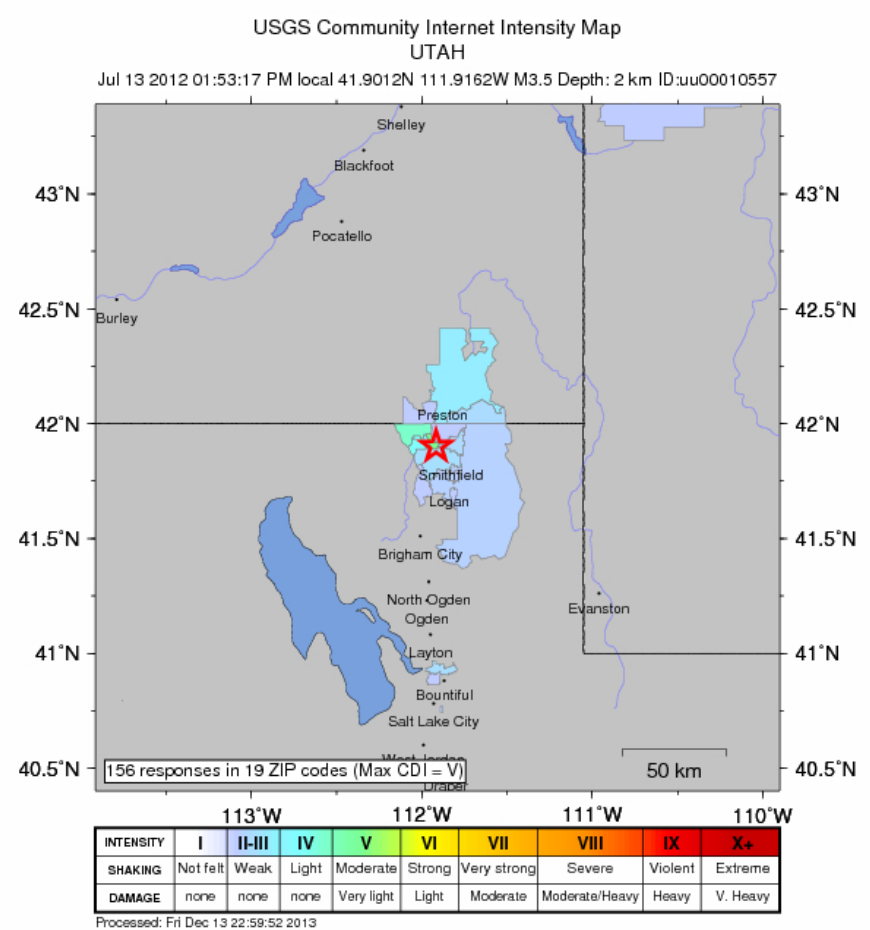

Figure A-4. Earthquake intensity maps for the: a) January 5, 2012 (07:20 UTC) $\mathrm{M}_{\mathrm{L}} 3.4$ earthquake located in Southeast Idaho; and b) July 13, 2012 (19:53 UTC) $\mathrm{M}_{\mathrm{L}} 3.5$ earthquake located in northern Utah (U.S. Geological Survey, 2014). 


\section{Appendix B}

\section{Instrument Response of NetDAS SMAs}

\section{B.1 Method for Determining Amplitude Response}

The instrument response (otherwise known as sensitivity) of the NetDAS-SMA is used to convert the measured counts of ground motion amplitude to units of $g$. Instrument responses for NetDAS units that have accelerometers mounted within the unit are determined by conducting 1-g (acceleration of gravity) tilt tests. These tests are done on a leveled pad at the IRC seismic lab or on the actual leveled pad at their physical location listed in Table 3. These 1-g tilt tests provide a relationship between the number of digitizer counts and the 1-g offset. Equation B-1 provides the conversion from the measured count level to actual $\mathrm{g}$ level for the recorded motion. Trigger threshold accelerations and counts/g are listed for NetDAS units with SMAs in Table B-1 using equation:

$$
\text { Acceleration }(\mathrm{g})=\text { Counts }_{(\text {Measured or target) }} /(\text { Counts } / g)
$$

For accelerographs without internally installed accelerometers within the NetDAS units, Equation B-1 does not apply due to an inability to perform analogous tilt tests. For all systems, however, there is a frequency dependent amplitude response, which is discussed further in Appendix C. Table B-2 lists the instrument response for these accelerometers using the methods discussed in Appendix C.

Tables B-1 and B-2 list the beginning and ending dates for the time periods that the instrument responses are applicable. Also, note that the building numbers and locations for the SMA codes are listed in Table 3. If changes occurred to SMA or seismic station instrumentation (such as accelerometer or NetDAS unit) during the year, then more than one range of dates are listed for a location. In cases where earthquakes have never been recorded by the unit, then only the most recent instrument response is included. As stated in Section 2.2, the accelerometers are set to trigger at thresholds $<0.005 \mathrm{~g}$. 
Table B-1. Instrument responses for strong-motion accelerographs (all have PAR4CH digitizers).

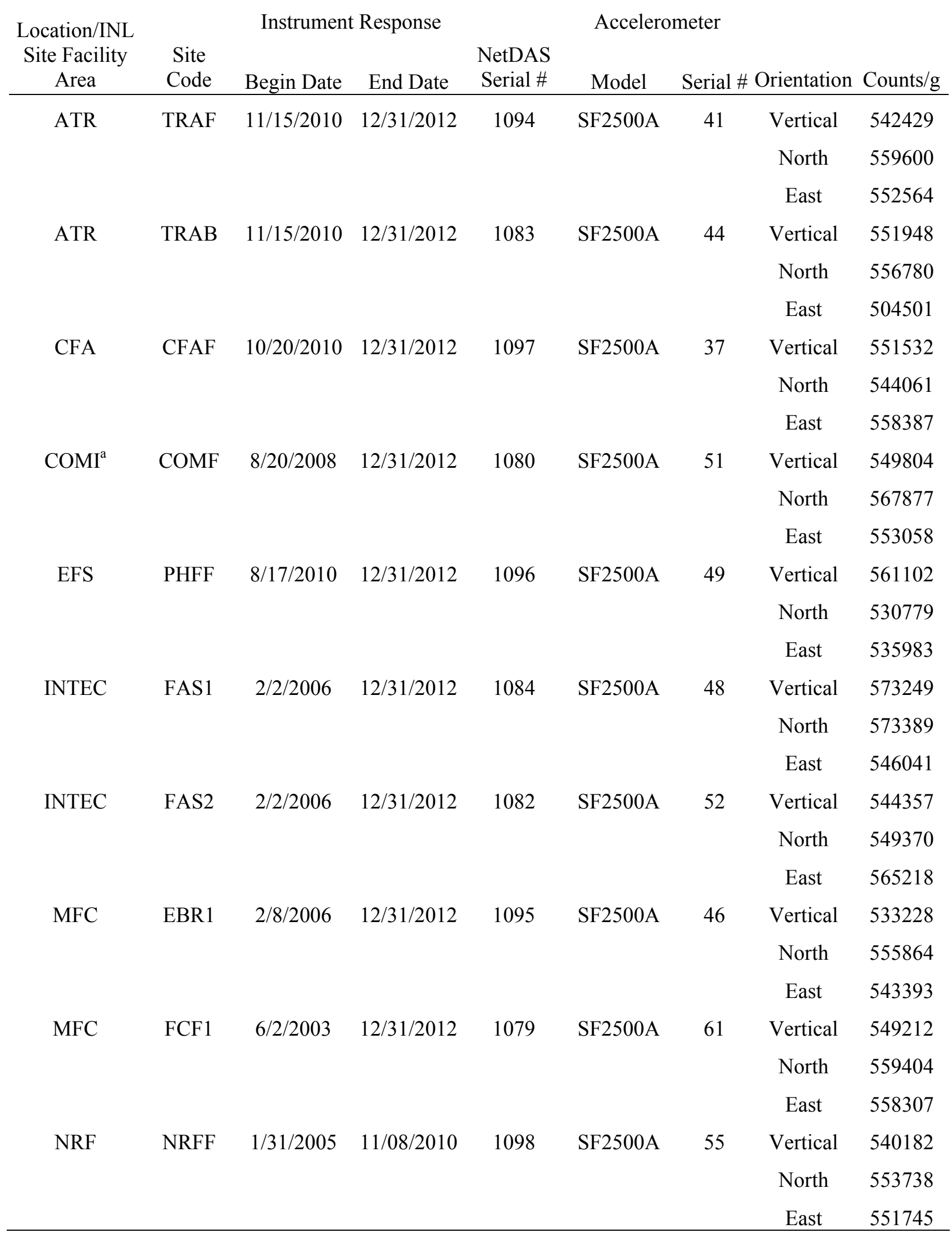


Table B-1. Continued.

\begin{tabular}{|c|c|c|c|c|c|c|c|c|}
\hline \multirow{2}{*}{$\begin{array}{c}\text { Location/INL } \\
\text { Site Facility } \\
\text { Area }\end{array}$} & \multirow[b]{2}{*}{$\begin{array}{l}\text { Site } \\
\text { Code }\end{array}$} & \multicolumn{2}{|c|}{ Instrument Response } & \multirow[b]{2}{*}{$\begin{array}{c}\text { NetDAS } \\
\text { Serial \# }\end{array}$} & \multicolumn{2}{|c|}{ Accelerometer } & \multirow[b]{2}{*}{ * Orientation } & \multirow[b]{2}{*}{ Counts/g } \\
\hline & & Begin Date & End Date & & Model & Serial \# & & \\
\hline \multirow[t]{3}{*}{ NRF } & NRFF & $11 / 08 / 2010$ & $12 / 31 / 2012$ & 1098 & SF2500A & 609 & Vertical & 473979 \\
\hline & & & & & & & North & 491200 \\
\hline & & & & & & & East & 489358 \\
\hline \multirow[t]{3}{*}{ NRF } & $\mathrm{A} 1 \mathrm{~W}$ & $11 / 08 / 2010$ & $12 / 31 / 2012$ & 1091 & SF2500A & 53 & Vertical & 548654 \\
\hline & & & & & & & North & 571896 \\
\hline & & & & & & & East & 555972 \\
\hline \multirow[t]{3}{*}{ NRF } & S1W & $1 / 31 / 2005$ & $12 / 31 / 2012$ & 1088 & SF2500A & 45 & Vertical & 561125 \\
\hline & & & & & & & North & 558488 \\
\hline & & & & & & & East & 558473 \\
\hline \multirow[t]{3}{*}{ PBF } & PBFF & $11 / 12 / 2008$ & $12 / 31 / 2012$ & 1089 & SF2500A & 50 & Vertical & 559649 \\
\hline & & & & & & & North & 550303 \\
\hline & & & & & & & East & 559707 \\
\hline \multirow[t]{3}{*}{$\mathrm{PBF}$} & ARAF & $10 / 20 / 2010$ & $12 / 31 / 2012$ & 1086 & SF2500A & 35 & Vertical & 527786 \\
\hline & & & & & & & North & 564825 \\
\hline & & & & & & & East & 547053 \\
\hline \multirow[t]{3}{*}{ RWMC } & RWMC & $9 / 20 / 2007$ & $12 / 31 / 2012$ & 1081 & SF2500A & 42 & Vertical & 552610 \\
\hline & & & & & & & North & 554529 \\
\hline & & & & & & & East & 572590 \\
\hline \multirow[t]{3}{*}{ RWMC } & RWME & $9 / 20 / 2007$ & $12 / 31 / 2012$ & 1077 & SF2500A & 40 & Vertical & 552358 \\
\hline & & & & & & & North & 540927 \\
\hline & & & & & & & East & 556424 \\
\hline \multirow[t]{3}{*}{ REC } & IRCF & $10 / 20 / 2010$ & $12 / 31 / 2012$ & 1093 & SF2500A & 47 & Vertical & 578185 \\
\hline & & & & & & & North & 570966 \\
\hline & & & & & & & East & 543190 \\
\hline \multirow[t]{3}{*}{ TAN } & TANA & $10 / 31 / 2008$ & $10 / 20 / 2010$ & 1090 & SF2500A & 56 & Vertical & 558999 \\
\hline & & & & & & & North & 557465 \\
\hline & & & & & & & East & 531326 \\
\hline \multirow[t]{3}{*}{ TAN } & TANA & $10 / 20 / 2010$ & $12 / 31 / 2012$ & 1090 & SF2500A & 56 & Vertical & 554009 \\
\hline & & & & & & & North & 556780 \\
\hline & & & & & & & East & 531537 \\
\hline
\end{tabular}


Table B-1. Continued.

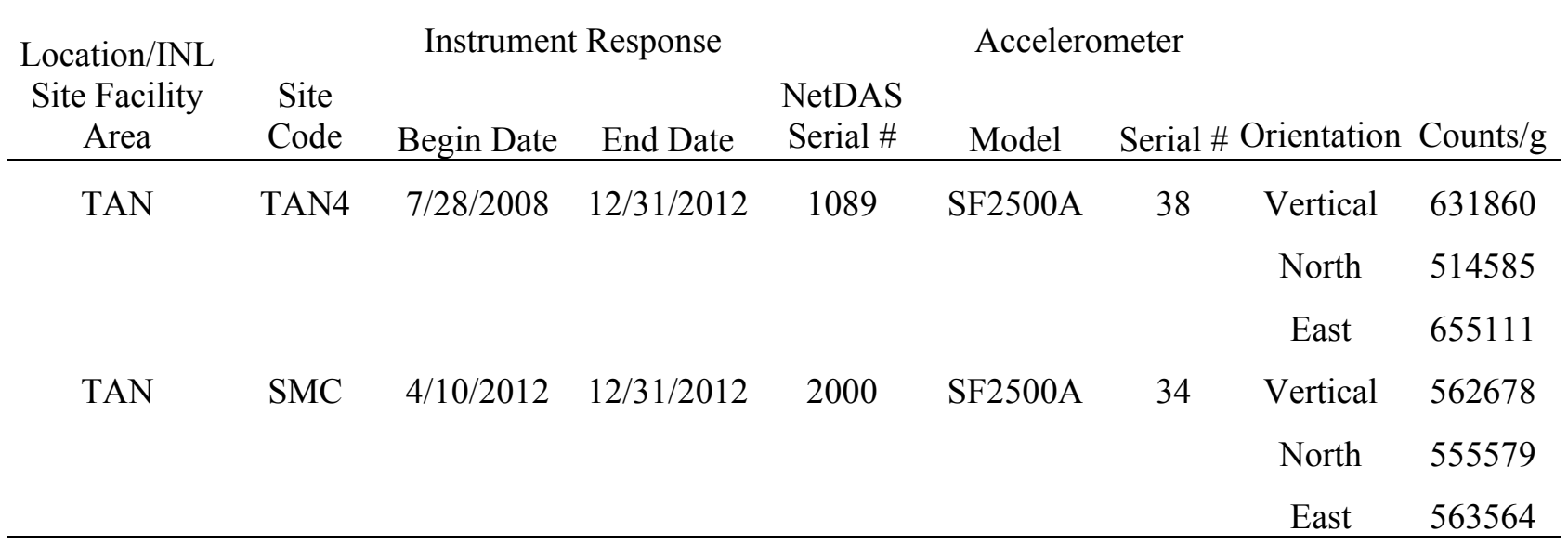

NA - Not available.

a. - SMA co-located at an INL seismic station. 
Table B-2. Instrument responses of accelerometers located at seismic stations.

\begin{tabular}{|c|c|c|c|c|c|c|c|c|c|}
\hline \multirow[b]{2}{*}{$\begin{array}{l}\text { Seismic } \\
\text { Station }\end{array}$} & \multicolumn{3}{|c|}{ Instrument Response } & \multicolumn{3}{|c|}{ Accelerometer } & \multirow[b]{2}{*}{$\begin{array}{c}\text { Datalogger } \\
\text { Counts/Volt }\end{array}$} & \multirow[b]{2}{*}{$\begin{array}{l}\text { Sensor } \\
\text { Volt/g }\end{array}$} & \multirow[b]{2}{*}{$\begin{array}{c}\text { Station } \\
\text { Counts/g }\end{array}$} \\
\hline & Begin Date & End Date & $\begin{array}{l}\text { NetDAS } \\
\text { Serial \# }\end{array}$ & Model \# & Serial \# & Orientation & & & \\
\hline \multirow[t]{3}{*}{$\mathrm{BCYI}$} & $5 / 06 / 2009$ & $12 / 31 / 2012$ & $1068^{\mathrm{a}}$ & SF3000L & 614 & Vertical & 2841402 & 1.220 & 3466510 \\
\hline & & & & & & North & 2834135 & 1.200 & 3400962 \\
\hline & & & & & & East & 2838854 & 1.220 & 3463402 \\
\hline \multirow[t]{3}{*}{ GRRI } & $11 / 04 / 2008$ & $12 / 31 / 2012$ & $1013^{b}$ & SF3000L & 185 & Vertical & 3932869 & 1.396 & 5490285 \\
\hline & & & & & & North & 4014708 & 1.345 & 5399782 \\
\hline & & & & & & East & 3980407 & 1.412 & 5620335 \\
\hline \multirow[t]{3}{*}{ HWFI } & $9 / 09 / 2008$ & $12 / 31 / 2012$ & $1069^{\mathrm{b}}$ & SF2500A & 62 & Vertical & 1757768 & 1.378 & 2422204 \\
\hline & & & & & & North & 1173136 & 1.371 & 1608369 \\
\hline & & & & & & East & 19243242 & 1.352 & 26016863 \\
\hline \multirow[t]{3}{*}{ NPRI } & $10 / 21 / 2005$ & $12 / 31 / 2012$ & $1065^{\mathrm{b}}$ & SF2500A & 36 & Vertical & 810927 & 1.427 & 1157193 \\
\hline & & & & & & North & 802533 & 1.376 & 1104285 \\
\hline & & & & & & East & 808520 & 1.371 & 1108481 \\
\hline \multirow[t]{3}{*}{ PTI } & $10 / 22 / 2008$ & $12 / 31 / 2012$ & $1071^{\mathrm{b}}$ & SF3000L & 188 & Vertical & 835018 & 1.230 & 1027072 \\
\hline & & & & & & North & 835559 & 1.194 & 997657 \\
\hline & & & & & & East & 835957 & 1.244 & 1039931 \\
\hline \multirow[t]{3}{*}{ SPCI } & $8 / 28 / 2007$ & $12 / 31 / 2012$ & $1070^{\mathrm{b}}$ & SF3000L & 186 & Vertical & 834485 & 1.216 & 1014734 \\
\hline & & & & & & North & 834508 & 1.237 & 1032286 \\
\hline & & & & & & East & 835579 & 1.215 & 1015228 \\
\hline
\end{tabular}




\section{Appendix C}

\section{Instrument Response of Seismic Stations}

\section{C.1 Method for Determining Instrument Gain}

The INL determines instrument responses (otherwise known as sensitivity) for both the four $(4 \mathrm{CH})$ and eight channel $(8 \mathrm{CH})$ NetDAS units. The INL establishes a DC counts/volt level by inputting a known voltage level for a specified duration of time for each channel on the NetDAS units and recording the mean and standard deviation in counts for this duration. The input voltage polarity is often reversed in order to obtain a greater measurement range. The mean provides the method to produce the $\mathrm{DC}$ counts/volt level (Equation C-1a and C-1b) and the standard deviation quantifies the measurement uncertainty and system noise.

Single ended:

$$
\text { Counts } / \text { Volt }=\mu / \mathrm{v}_{\mathrm{i}}
$$

Reversed Polarity:

$$
\text { Counts } / \text { Volt }=\left(\mu+-\mu^{-}\right) /\left(v_{i}+-v_{i}^{-}\right)
$$

Where:

$$
\begin{aligned}
& \mu \text { is mean counts } \\
& \mathrm{v}_{\mathrm{i}} \text { is input voltage } \\
& \text { Subscript "+" is positive polarity } \\
& \text { Subscript "_- " is negative polarity }
\end{aligned}
$$

\section{C.2 NetDAS-4CH Frequency Response}

The response of the Symmetric Research PAR4CH (4CH) digitizer used in the NetDAS-4CH was calculated at the INL to establish the instrument response of NetDAS units and the methods incorporated vendor information. The DAQSystems, Inc., manufacturer of the NetDAS units, reviewed INL's frequency response results and methods, which is discussed in the following steps.

The NetDAS-4CH frequency response was determined empirically by measuring the output counts resulting from a known input signal. Trials were conducted using a constant-amplitude sine wave with frequencies varying between $0.1,5,10,15,20,25,30$, and $35 \mathrm{~Hz}$. The frequency sweep was performed twice for those frequencies. The averages of the measured counts at each frequency were then converted into decibel responses relative to the average response at $0.1 \mathrm{~Hz}$, because the vendor data sheets list a gain of 1 at this frequency. A $2^{\text {nd }}$ order polynomial was then fit to the data creating a simple amplitude response in frequency. The perfectly matched response (R-squared of one) is shown here as described by Equations C-2 and C-3 (conversion to decibels).

$$
\begin{aligned}
& Y_{d B}=-0.0045 f^{2}+0.0074 f-0.014 \\
& d B=20 \log \left(E_{2} / E_{1}\right)
\end{aligned}
$$


Where:

$$
\begin{aligned}
& f-\text { frequency }(\mathrm{Hz}) \\
& E_{1}-\text { original signal level } \\
& E_{2}-\text { modified signal level } \\
& E_{2} / E_{1}-\text { commonly referred to as gain }
\end{aligned}
$$

This relationship was then used to calculate the gains out to the Nyquist frequency $(1 / 2$ the sample rate). The INL samples all data at 100 samples per second or $0.01 \mathrm{~Hz}$. The information was then entered into MATLAB, which has a function to determine poles and zeros. Poles and zeros are the instrument response format that many seismic applications use to correct seismograms for instrument response. The NetDAS-4CH frequency response in $\mathrm{dB}$ and poles and zeros are shown in Figure $\mathrm{C}-1$.

Equations C-2 and C-3 can be used in conjunction with the DC counts/volt measurement to generate a count-based frequency response for short hand calculations or spectral deconvolution to remove the frequency response.

$$
\text { Ycounts }=\text { Counts } / \text { Volt } \times 10^{\wedge}\left(\left(-0.0045 \mathrm{f}^{2}+0.0074 \mathrm{f}-0.014\right) / 20\right)
$$

Where:

$$
\wedge \text { - Indicates } 10 \text { to the power of the number calculated in parentheses. }
$$

However, the preferred method for removing the frequency response from a recorded waveform is to use a seismic analysis package, such as SEISAN. This program recognizes the poles and zeros representation of instrument response, which quickly and accurately corrects recorded waveforms to actual ground motions.

\section{C.3 NetDAS-8CH Frequency Response}

The response of the Symmetric Research PAR24B (8CH) digitizer used in the NetDAS-8CH was based on vendor provided information, and calculated in the same method as described above for the PAR4CH. A $2^{\text {nd }}$ order polynomial was fit to the data creating a simple amplitude response in frequency that matched the amplitude response (R-squared of 0.999). Equation C-5, listed below, is similar to Equation C-3 used for the response of the NetDAS-4CH. The NetDAS-8CH frequency response in $\mathrm{dB}$ and poles and zeros are shown in Figure $\mathrm{C}-2$.

$$
Y_{\mathrm{dB}}=-0.0045 f^{2}+0.0071 f-0.0158
$$

\section{C.4 Short-period seismic station frequency response data}

In the fall of 2002, INL seismic personnel began tracking instrument response of the seismic stations. These response values, in combination with the instrument frequency responses (see C.2 and C.3), are used to create site- and date-specific system response files for the INL seismic stations. These response files are used in SEISAN to correct waveforms for further analyses such as calculating magnitudes by measuring amplitudes. Table $\mathrm{C}$-1 lists the most recent measured responses (including any system amplification) for the seismic stations that have been measured for instrument responses (in counts/volt). 


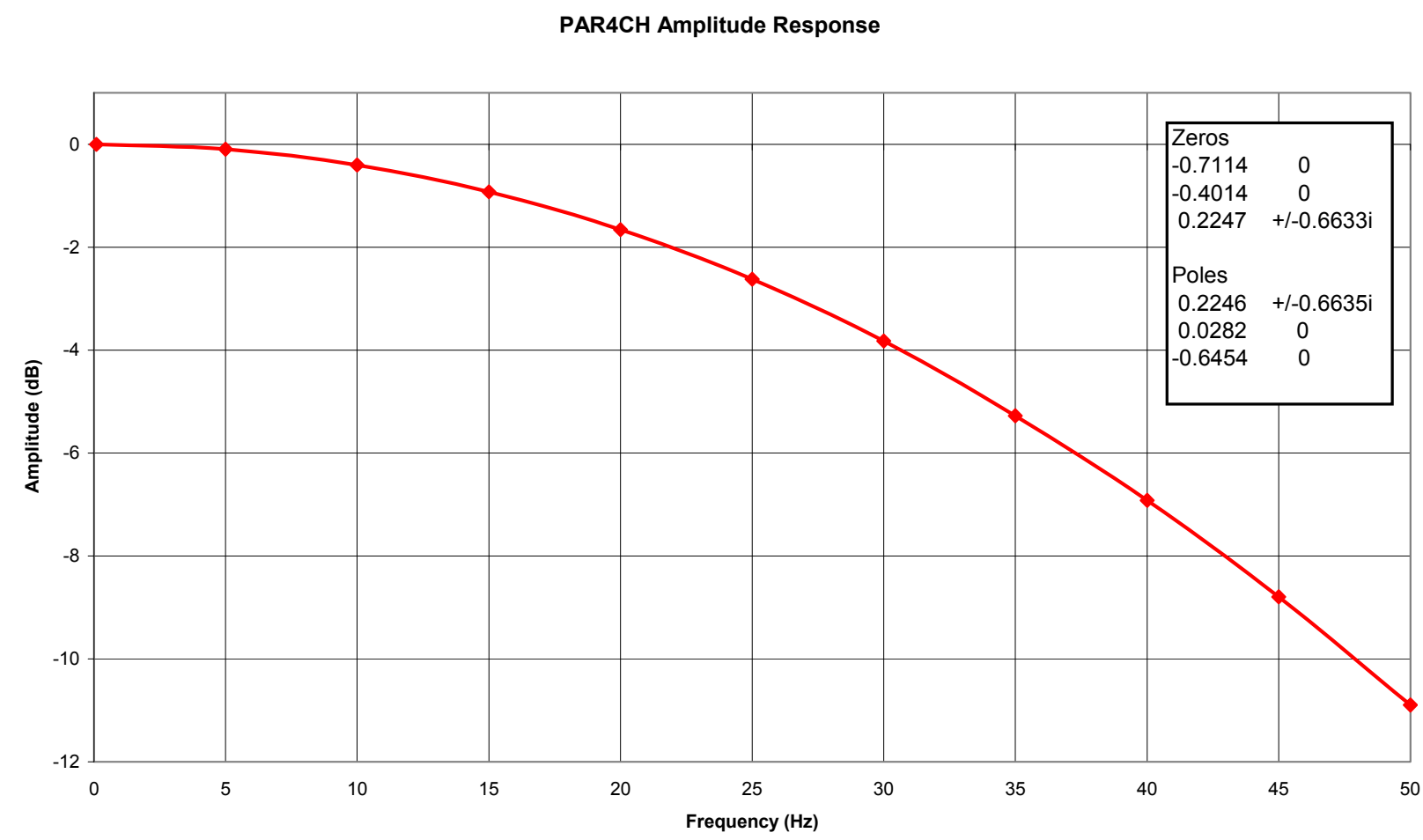

Figure C-1. Amplitude verses frequency system response of the Symmetric Research PAR4CH digitizer used in the NetDAS-4CH. 


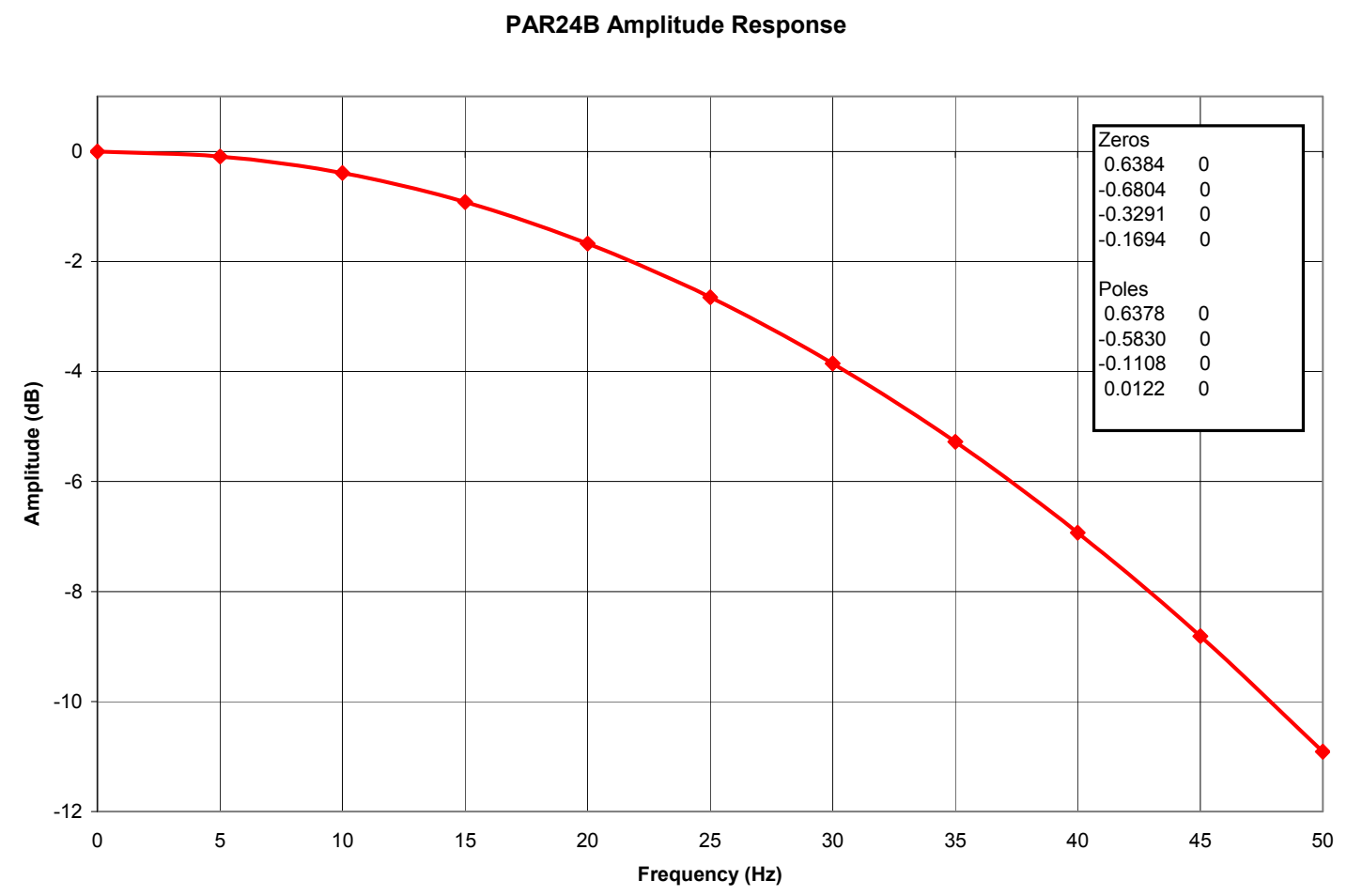

Figure C-2. Amplitude verses frequency system response of the Symmetric Research PAR24B digitizer used in the NetDAS- $8 \mathrm{CH}$. 
Table C-1. Instrument responses of seismometers located at seismic stations.

\begin{tabular}{|c|c|c|c|c|c|c|c|}
\hline $\begin{array}{l}\text { Seismic } \\
\text { Station }\end{array}$ & Begin Date & Response & $\begin{array}{c}\text { NetDAS } \\
\text { Serial \# }\end{array}$ & $\begin{array}{c}\text { Digitizer } \\
\text { Model }\end{array}$ & Orientation & $\begin{array}{l}\text { Datalogger } \\
\text { Counts/Volt }\end{array}$ & $\begin{array}{c}\text { Seismometer } \\
\text { Model }\end{array}$ \\
\hline \multicolumn{8}{|c|}{ Single-component seismic stations } \\
\hline ARNI & $8 / 28 / 2007$ & $12 / 31 / 2012$ & 1017 & $4 \mathrm{CH}$ & Vertical & 47977741 & S13J \\
\hline BCYI & $5 / 06 / 2009$ & $5 / 24 / 2012$ & 1068 & 24USB5V & Vertical & 2840730 & S13J \\
\hline BCYI & $5 / 24 / 2012$ & $12 / 31 / 2012$ & 1068 & 24USB5V & Vertical & Not Measured & L4C \\
\hline CBTI & $8 / 29 / 2007$ & $12 / 31 / 2012$ & 1024 & $4 \mathrm{CH}$ & Vertical & 48948934 & S13J \\
\hline $\mathrm{CNCI}$ & $9 / 29 / 2009$ & $12 / 31 / 2012$ & 1066 & 24USB5V & Vertical & 2851620 & $\mathrm{~L} 4 \mathrm{C}$ \\
\hline COMI & $9 / 21 / 2007$ & $12 / 31 / 2012$ & 2005 & $4 \mathrm{CH}$ & Vertical & 36022837 & S13 \\
\hline CRBI & $8 / 28 / 2006$ & $12 / 31 / 2012$ & 1027 & $4 \mathrm{CH}$ & Vertical & 401458 & S13J \\
\hline COMI & $12 / 03 / 2008$ & $12 / 31 / 2012$ & 1025 & 24USB5V & Vertical & 2834323 & $\mathrm{~S} 13$ \\
\hline ECRI & $10 / 23 / 2009$ & $12 / 31 / 2012$ & 1051 & $4 \mathrm{CH}$ & Vertical & 46797192 & $\mathrm{~S} 13$ \\
\hline EMI & $9 / 13 / 2007$ & $12 / 31 / 2012$ & 1019 & $4 \mathrm{CH}$ & Vertical & 48487157 & L4C \\
\hline GBI & $12 / 01 / 2009$ & $4 / 18 / 2012$ & 30802 & 24USB5V & Vertical & 2838478 & $\mathrm{~S} 13 \mathrm{~J}$ \\
\hline GBI & 4/18/2009 & $12 / 31 / 2012$ & 30802 & 24USB5V & Vertical & Not Measured & $\mathrm{L} 4 \mathrm{C}$ \\
\hline GRRI & $11 / 04 / 2008$ & $12 / 31 / 2012$ & 1013 & 24USB5V & Vertical & 2831677 & $\mathrm{~L} 4 \mathrm{C}$ \\
\hline \multirow[t]{2}{*}{ GTRI } & $11 / 24 / 2008$ & $12 / 31 / 2012$ & 9001 & 24USB5V & $\begin{array}{l}\text { Vertical - } \\
\text { borehole }\end{array}$ & 2776147 & $\mathrm{~L} 4 \mathrm{C}$ \\
\hline & $11 / 24 / 2008$ & $12 / 31 / 2012$ & 9001 & 24USB5V & $\begin{array}{l}\text { Vertical - } \\
\text { surface }\end{array}$ & 2949858 & $\mathrm{~L} 4 \mathrm{C}$ \\
\hline HHAI & $10 / 22 / 2008$ & $12 / 31 / 2012$ & 1014 & $4 \mathrm{CH}$ & Vertical & 458174 & L4C \\
\hline HPI & $9 / 13 / 2007$ & $12 / 31 / 2012$ & 1015 & $4 \mathrm{CH}$ & Vertical & 47682925 & L4C \\
\hline ICI & $9 / 13 / 2007$ & $12 / 31 / 2012$ & 1020 & $4 \mathrm{CH}$ & Vertical & 48888117 & $\mathrm{~L} 4 \mathrm{C}$ \\
\hline
\end{tabular}


Table C-1. Continued.

\begin{tabular}{|c|c|c|c|c|c|c|c|}
\hline \multicolumn{8}{|c|}{ Instrument Response } \\
\hline $\begin{array}{l}\text { Seismic } \\
\text { Station }\end{array}$ & Begin Date & End Date & $\begin{array}{l}\text { NetDAS } \\
\text { Serial \# }\end{array}$ & $\begin{array}{l}\text { Digitizer } \\
\text { Model }\end{array}$ & Orientation & $\begin{array}{c}\text { Datalogger } \\
\text { Counts/Volt }\end{array}$ & $\begin{array}{c}\text { Seismometer } \\
\text { Model }\end{array}$ \\
\hline KBI & $8 / 28 / 2007$ & $12 / 31 / 2012$ & 1018 & $4 \mathrm{CH}$ & Vertical & 45839400 & S13J \\
\hline LJI & $9 / 09 / 2008$ & $12 / 31 / 2012$ & 1052 & $4 \mathrm{CH}$ & Vertical & 48429387 & $\mathrm{~S} 13 \mathrm{~J}$ \\
\hline PTI & $10 / 22 / 2008$ & $12 / 31 / 2012$ & 1071 & $8 \mathrm{CH}$ & Vertical & 86459806 & $\mathrm{~S} 13$ \\
\hline PZCI & $9 / 11 / 2008$ & $12 / 31 / 2012$ & 1023 & $4 \mathrm{CH}$ & Vertical & 47216457 & S13J \\
\hline SMBI & $9 / 10 / 2008$ & $12 / 31 / 2012$ & 1064 & 24USB5V & Vertical & 2835711 & $\mathrm{~L} 4 \mathrm{C}$ \\
\hline TCSI & $9 / 10 / 2008$ & $12 / 31 / 2012$ & 1010 & 24USB5V & Vertical & 2873122 & $\mathrm{~L} 4 \mathrm{C}$ \\
\hline \multicolumn{8}{|c|}{ Three-component seismic stations } \\
\hline \multirow[t]{3}{*}{ HWFI } & $9 / 09 / 2008$ & $12 / 31 / 2012$ & 1069 & $8 \mathrm{CH}$ & Vertical & 86375959 & S13 \\
\hline & & & & & North & 86381403 & $\mathrm{~S} 13$ \\
\hline & & & & & East & 84982876 & $\mathrm{~S} 13$ \\
\hline \multirow[t]{3}{*}{ IRCI } & $4 / 22 / 2010$ & $12 / 31 / 2012$ & 1012 & $4 \mathrm{CH}$ & Vertical & 456044 & $\mathrm{~S} 13$ \\
\hline & & & & & North & 459462 & $\mathrm{~S} 13$ \\
\hline & & & & & East & 462104 & $\mathrm{~S} 13$ \\
\hline \multirow[t]{3}{*}{ JGI } & $9 / 11 / 2008$ & $12 / 31 / 2012$ & 30801 & 24USB5V & Vertical & 2856927 & $\mathrm{~S} 13$ \\
\hline & & & & & North & 2887634 & S13 \\
\hline & & & & & East & 2867169 & $\mathrm{~S} 13$ \\
\hline \multirow[t]{3}{*}{ LLRI } & $5 / 12 / 2011$ & $12 / 31 / 2012$ & 1029 & 24USB5V & Vertical & 2830795 & $\mathrm{~L} 4 \mathrm{C}$ \\
\hline & & & & & North & 2840055 & $\mathrm{~S} 13$ \\
\hline & & & & & East & 2767350 & $\mathrm{~S} 13$ \\
\hline
\end{tabular}


Table C-1. Continued.

\begin{tabular}{|c|c|c|c|c|c|c|c|}
\hline \multicolumn{8}{|c|}{ Instrument Response } \\
\hline $\begin{array}{l}\text { Seismic } \\
\text { Station }\end{array}$ & Begin Date & End Date & $\begin{array}{l}\text { NetDAS } \\
\text { Serial \# }\end{array}$ & $\begin{array}{c}\text { Digitizer } \\
\text { Model }\end{array}$ & Orientation & $\begin{array}{c}\text { Datalogger } \\
\text { Counts/Volt }\end{array}$ & $\begin{array}{c}\text { Seismometer } \\
\text { Model }\end{array}$ \\
\hline NPRI & $4 / 22 / 2011$ & $12 / 31 / 2012$ & 1065 & $8 \mathrm{CH}$ & Vertical & 836486 & $\mathrm{~L} 4 \mathrm{C}$ \\
\hline NPRI & $10 / 21 / 2005$ & $12 / 31 / 2012$ & 1065 & $8 \mathrm{CH}$ & North & 837155 & $\mathrm{~S} 13$ \\
\hline NPRI & $10 / 21 / 2005$ & $12 / 31 / 2012$ & 1065 & $8 \mathrm{CH}$ & East & 839175 & S13 \\
\hline \multirow[t]{3}{*}{ SPCI } & $8 / 28 / 2007$ & $12 / 31 / 2012$ & 1070 & $8 \mathrm{CH}$ & Vertical & 83330000 & $\mathrm{~S} 13 \mathrm{~J}$ \\
\hline & & & & & North & 83376700 & $\mathrm{~S} 13$ \\
\hline & & & & & East & 83485300 & $\mathrm{~S} 13$ \\
\hline \multirow[t]{3}{*}{ TCSI } & $9 / 10 / 2008$ & $12 / 03 / 2012$ & 1010 & 24USB5V & Vertical & 2873122 & $\mathrm{~L} 4 \mathrm{C}$ \\
\hline & & & & & North & 2887077 & $\mathrm{~S} 13$ \\
\hline & & & & & East & 2868820 & $\mathrm{~S} 13$ \\
\hline \multirow[t]{3}{*}{ TMI } & $9 / 22 / 2009$ & $12 / 31 / 2012$ & 2004 & 24USB5V & Vertical & 2849495 & $\mathrm{~S} 13$ \\
\hline & & & & & North & 2848510 & $\mathrm{~S} 13$ \\
\hline & & & & & East & 2844713 & $\mathrm{~S} 13$ \\
\hline
\end{tabular}

Note: The 4CH (PAR4CH) and 24USB5V (DAQ24USB5V) digitizers have the same poles and zeros, and are different from the poles and zeros for the 8CH (PAR24B). 


\section{C.5 Broadband seismometer frequency response}

The INL seismic network has two broadband seismic stations (I14A and NPRI; see Section 2.1) which have two different types of sensors. Seismic station I14A has the three-component, Guralp CMG3T (serial \#T34313) broadband seismometer with a power consumption of $60 \mathrm{~mA}$ at $12 \mathrm{~V}$ input and a calibration resistor of 51,000 $\Omega$. Table C-2 lists the seismometer sensitivity data and Table C-3 lists the seismometer frequency response data (in poles and zeros) for each component as determined on 12/20/2006 by EarthScope. The data acquisition system is a Quanterra Q330 (ID tag \# 1554), the frequency is unity within the sampling rates employed at this station. The NPRI seismic station has the three-component, Nanometrics Trillium T120-PA broadband seismometer (serial \#001025) has the combined sensitivity response nominal parameters listed in Table C-4. Table C-5 list the response for seven poles and five zeros provided by Nanometrics. The data acquisition system is a Quanterra Q330 (ID tag \# 3870), the frequency is unity within the sampling rates employed at this station.

Table C-2. EarthScope-determined Guralp CMG-3T (serial \#T34313) seismometer sensitivity.

\begin{tabular}{cccc}
\hline Component & $\begin{array}{c}\text { Velocity Output } \\
(\mathrm{V} / \mathrm{m} / \mathrm{s}) \\
(\text { Differential) }\end{array}$ & $\begin{array}{c}\text { Mass Position Output } \\
(\mathrm{V} / \mathrm{m} / \mathrm{s} 2) \\
(\text { Acceleration output) }\end{array}$ & $\begin{array}{c}\text { Feedback Coil } \\
\text { Constant(Amp/m/s2) }\end{array}$ \\
\hline Vertical & $2 \times 741$ & 1887 & 0.02516 \\
North/South & $2 \times 750$ & 2023 & 0.02697 \\
East/West & $2 \times 745$ & 2010 & 0.0268 \\
\hline
\end{tabular}

Note: A factor of $2 \mathrm{x}$ must be used when the sensor outputs are used differentially (also known as push-pull or balanced output).

Table C-3. EarthScope-determined Guralp CMG-3T (serial \#T34313) seismometer frequency response.

\begin{tabular}{cccc}
\hline Component & Poles $(\mathrm{Hz})$ & Zeros $(\mathrm{Hz})$ & $\begin{array}{c}\text { Normalizing factor } \\
\text { at } 1 \mathrm{~Hz}\end{array}$ \\
\hline \multirow{2}{*}{ Vertical } & $-5.89 \times 10^{-3} \pm \mathrm{j} 5.89 \times 10^{-3}$ & 0 & 2304000 \\
-180 & 0 & \\
& -160 & & \\
& -80 & & \\
& $-5.89 \times 10^{-3} \pm \mathrm{j} 5.89 \times 10^{-3}$ & 0 & \\
Horizontal & -180 & 0 & \\
$(\mathrm{~N}-\mathrm{S}$ and E-W $)$ & -160 & & \\
& -80 & & \\
\hline
\end{tabular}


Table C-4. Combined calibration response nominal parameters for Nanometrics Trillium T120-PA (serial \#001025) seismometer.

\begin{tabular}{cc}
\hline Parameter* & Nominal Values \\
\hline Zeros ( $\mathrm{z}_{\mathrm{n}}$ in radians/second) & 0 \\
& -90.0 \\
& $-0.03852 \pm 0.03658 \mathrm{i}$ \\
Poles ( $\mathrm{p}_{\mathrm{n}}$ in radians/second) & -178 \\
& $-135 \pm 160 \mathrm{i}$ \\
Normalization factor ( $\kappa$ in radians/second) & $-671 \pm 1154 \mathrm{i}$ \\
Normalization Frequency ( $\mathrm{f}_{0}$ in $\left.\mathrm{Hz}\right)$ & $1.540 \times 10^{11}$ \\
Combined calibration sensitivity at $\mathrm{f}_{0}$ & 1 \\
(radians/second)
\end{tabular}

* The units of the nominal values are $\mathrm{rad} / \mathrm{s}$ because the calibration input produces an equivalent acceleration, while the seismometer passband is flat to velocity. Therefore, to determine the expected gain for a sinusoidal calibration, you must divide the sensitivity listed above by $2 \pi \mathrm{f}$, where $\mathrm{f}$ is the frequency of the sinusoid.

Table C-5. Poles and zeros for the Nanometrics Trillium T120-PA (serial \#001025) seismometer.

\begin{tabular}{ccc} 
& Poles & \\
\hline$-3.852 \times 10^{-2}$ & & $3.658 \times 10^{-2}$ \\
$-3.852 \times 10^{-2}$ & $-3.658 \times 10^{-2}$ \\
$-1.78 \times 10^{-2}$ & 0.000 \\
$-1.35 \times 10^{2}$ & $1.60 \times 10^{2}$ \\
$-1.35 \times 10^{2}$ & $-1.60 \times 10^{2}$ \\
$-6.71 \times 10^{2}$ & $11.54 \times 10^{2}$ \\
$-6.71 \times 10^{2}$ & & $-11.54 \times 10^{2}$ \\
& Zeros & \\
0.00 & & 0.00 \\
0.00 & & 0.00 \\
$-0.90 \times 10^{2}$ & 0.00 \\
$-1.607 \times 10^{2}$ & 0.00 \\
$-31.080 \times 10^{2}$ & & 0.00 \\
\hline
\end{tabular}




\section{Appendix D}

\section{Earthquake List}

The summary list of earthquakes includes those located within a $161-\mathrm{km}(100-$ mile) radius of the INL centered at $43.0^{\circ} 39.00^{\prime} \mathrm{N}, 112^{\circ} 47.00^{\prime} \mathrm{W}$. Table D-1 provides an explanation of the headings listed in Table D-2 for the earthquake list. The format for this table has been modified from previous years. The earthquake identification number is no longer reported since the SEISAN analysis package identification number is simply the origin data and time. The listing also includes the distance of the earthquake epicenter from the center of INL. 
Table D-1. Explanation of the earthquake summary table headings.

\begin{tabular}{|c|c|c|}
\hline Heading & Example & Explanation \\
\hline ORIGIN & 1/1/2012 1:20:05 & $\begin{array}{l}\text { Date of the earthquake: month/day/year; origin time of the } \\
\text { earthquake: hour, minute, and second in UTC }\end{array}$ \\
\hline LAT N & 44.3367 & Latitude of epicenter in degrees North \\
\hline LONG W & -114.2208 & Longitude of epicenter in degrees West \\
\hline MAG- & 1.9 & $\begin{array}{l}\text { Magnitude of the earthquake. NM signifies that no magnitude } \\
\text { was determined for this earthquake. }\end{array}$ \\
\hline TYPE & Mc IE & $\begin{array}{l}\text { Type of magnitude reported and reporting agency. Magnitude } \\
\text { types: Coda magnitude (Mc); Local magnitude (ML); } \\
\text { Moment magnitude (Mw); and Body wave magnitude (mb). } \\
\text { Reporting agencies include: Idaho National Laboratory (IE); } \\
\text { NEIC (US); University of Utah (UU); and Montana Bureau } \\
\text { of Mines and Geology (MB); Wyoming (WY). NM with a } \\
\text { magnitude of } 0.00 \text { indicates that no magnitude was calculated } \\
\text { as a result of multiple earthquakes, which obscures the coda } \\
\text { of the first event or the record length was insufficient to } \\
\text { include the full coda of the earthquake. }\end{array}$ \\
\hline DIST & 138.3 & $\begin{array}{l}\text { Distance in km from center of INL at: } 43^{\circ} 39.00^{\prime} \mathrm{N} \text {, } \\
112^{\circ} 47.00^{\prime} \mathrm{W} \text {. }\end{array}$ \\
\hline $\mathrm{Z}$ & 4.96 & $\begin{array}{l}\text { Calculated focal depth in } \mathrm{km} \text {. Not all earthquakes have } \\
\text { appropriate seismic station geometry for calculating a reliable } \\
\text { focal depth, thus the errors (ERZ) are typically large. }\end{array}$ \\
\hline NO & 8 & $\begin{array}{l}\text { Number of station readings used in locating the earthquake } \\
\text { with weights above } 0.1 \text {. P- and S-wave arrival times for the } \\
\text { same station are regarded as two readings. }\end{array}$ \\
\hline GAP & 232 & Largest azimuthal separation in degrees between stations. \\
\hline DMIN & 65.1 & Distance in $\mathrm{km}$ from the epicenter to the nearest station. \\
\hline \multirow[t]{2}{*}{ RMS } & 0.06 & $\begin{array}{l}\text { Root mean square error of arrival time residuals in second } \\
\text { using all weights as calculated by: } \mathrm{RMS}=\mathrm{SQRT}\left(\Sigma \mathrm{W}_{\mathrm{i}}^{*} \mathrm{R}_{\mathrm{i}}^{2} / \mathrm{N}\right)\end{array}$ \\
\hline & & $\begin{array}{l}\text { Where: SQRT is the square root; } \Sigma \mathrm{W}_{\mathrm{i}}{ }^{*} \mathrm{R}_{\mathrm{i}} \text { is the sum of the } \\
\text { time residuals for the } \mathrm{i}^{\text {th }} \text { arrival times the weight assigned to } \\
\text { that arrival time; and } \mathrm{N} \text { is the number of residuals. }\end{array}$ \\
\hline $\mathrm{ERH}$ & 1.1 & Standard horizontal error of the epicenter in $\mathrm{km}$. \\
\hline ERZ & 3.8 & Standard vertical error of the focal depth in $\mathrm{km}$. \\
\hline
\end{tabular}


Table D-2. Earthquakes located within 161-km radius of INL in 2012.

\begin{tabular}{|c|c|c|c|c|c|c|c|c|c|c|c|}
\hline ORIGIN TIME & LAT N & LONG W & MAG-TYPE & DIST & Z & $\mathrm{NO}$ & GAP & DMIN & RMS & $\mathrm{ERH}$ & $\mathrm{ERZ}$ \\
\hline 1/1/2012 1:20:05 & 44.3367 & -114.2208 & 1.9 Mc IE & 138.3 & 4.96 & 8 & 232 & 65.1 & 0.06 & 1.1 & 3.8 \\
\hline 1/1/2012 14:41:32 & 44.1958 & -113.9703 & 1.3 Mc IE & 113.0 & 8.79 & 7 & 227 & 46.9 & 0.04 & 1.0 & 12.7 \\
\hline 1/2/2012 1:09:38 & 43.0590 & -112.2075 & 1.3 Mc IE & 80.6 & 8.53 & 14 & 112 & 24.8 & 0.07 & 0.4 & 1.2 \\
\hline 1/3/2012 7:21:52 & 44.6683 & -112.1003 & 1.3 Mc IE & 125.8 & 12.63 & 8 & 118 & 24.8 & 0.08 & 0.7 & 1.7 \\
\hline 1/3/2012 13:46:17 & 43.2737 & -110.9338 & 1.0 ML IE & 155.3 & 2.26 & 11 & 159 & 11.9 & 0.11 & 0.8 & 14.1 \\
\hline 1/4/2012 1:19:54 & 44.3622 & -112.6812 & $2.5 \mathrm{Mc} \mathrm{IE}$ & 79.7 & 11.53 & 22 & 90 & 34.4 & 0.06 & 0.4 & 1.8 \\
\hline $1 / 4 / 2012$ 18:48:53 & 42.9832 & -111.3220 & $0.7 \mathrm{Mc} \mathrm{IE}$ & 139.8 & 0.05 & 7 & 115 & 8.8 & 0.08 & 2.0 & 3.6 \\
\hline 1/5/2012 13:39:32 & 43.2112 & -111.3795 & $0.9 \mathrm{Mc} \mathrm{IE}$ & 123.6 & 5.97 & 8 & 213 & 17.5 & 0.06 & 1.2 & 7.0 \\
\hline 1/6/2012 21:46:38 & 42.8983 & -111.2803 & 1.0 Mc IE & 147.9 & 9.14 & 8 & 156 & 12.4 & 0.06 & 1.3 & 4.6 \\
\hline $1 / 6 / 2012$ 21:47:40 & 42.8962 & -111.2838 & 1.3 ML IE & 147.8 & 10.89 & 11 & 159 & 12.2 & 0.05 & 0.9 & 2.7 \\
\hline 1/7/2012 10:19:15 & 44.1325 & -113.9632 & $1.3 \mathrm{Mc} \mathrm{IE}$ & 108.9 & 7.19 & 8 & 215 & 46.8 & 0.11 & 1.0 & 15.4 \\
\hline 1/7/2012 10:31:50 & 44.1272 & -113.9557 & $1.5 \mathrm{Mc} \mathrm{IE}$ & 108.1 & 6.96 & 11 & 213 & 46.0 & 0.05 & 0.7 & 13.2 \\
\hline 1/9/2012 7:44:07 & 44.7550 & -111.7653 & 1.0 ML IE & 147.4 & 9.27 & 8 & 152 & 8.4 & 0.03 & 0.9 & 1.0 \\
\hline 1/10/2012 2:18:36 & 44.6890 & -111.8945 & $1.9 \mathrm{Mc} \mathrm{IE}$ & 135.7 & 6.22 & 14 & 111 & 18.7 & 0.04 & 0.5 & 9.3 \\
\hline 1/10/2012 5:06:52 & 44.1807 & -112.9923 & 1.2 Mc IE & 61.4 & 8.42 & 9 & 240 & 29.6 & 0.08 & 1.5 & 10.5 \\
\hline 1/10/2012 16:07:15 & 42.6675 & -111.4812 & $1.1 \mathrm{Mc} \mathrm{IE}$ & 152.1 & 5.08 & 5 & 299 & 30.5 & 0.04 & 2.9 & 11.2 \\
\hline 1/11/2012 7:19:28 & 44.8360 & -112.9728 & $1.3 \mathrm{Mc} \mathrm{IE}$ & 132.8 & 7.21 & 6 & 175 & 9.8 & 0.05 & 5.1 & 10.3 \\
\hline 1/11/2012 7:29:57 & 42.9125 & -111.2090 & $1.3 \mathrm{Mc} \mathrm{IE}$ & 151.8 & 10.97 & 10 & 121 & 17.6 & 0.06 & 0.5 & 2.7 \\
\hline 1/11/2012 17:10:57 & 42.6468 & -111.4022 & $1.6 \mathrm{Mc} \mathrm{IE}$ & 158.3 & 8.38 & 13 & 108 & 28.0 & 0.08 & 0.5 & 4.2 \\
\hline 1/11/2012 23:00:49 & 44.0583 & -113.9465 & 1.4 Mc IE & 104.0 & 7.15 & 9 & 201 & 42.2 & 0.07 & 0.7 & 13.8 \\
\hline $1 / 13 / 2012$ 10:47:13 & 42.8457 & -111.2378 & 1.0 ML IE & 154.1 & 11.32 & 9 & 177 & 14.4 & 0.06 & 1.0 & 2.7 \\
\hline 1/13/2012 14:16:00 & 44.3158 & -111.0100 & $0.7 \mathrm{Mc} \mathrm{IE}$ & 160.3 & 4.66 & 4 & 241 & 17.1 & 0.04 & 2.7 & 12.2 \\
\hline 1/14/2012 16:20:16 & 44.6710 & -112.1117 & $2.6 \mathrm{ML} \mathrm{IE}$ & 125.6 & 12.77 & 19 & 105 & 24.0 & 0.03 & 0.4 & 1.4 \\
\hline 1/14/2012 16:58:54 & 44.6677 & -112.1132 & $2.3 \mathrm{Mc} \mathrm{IE}$ & 125.2 & 15.07 & 20 & 104 & 23.8 & 0.04 & 0.3 & 0.7 \\
\hline 1/15/2012 20:23:29 & 44.5890 & -112.3997 & $1.3 \mathrm{Mc} \mathrm{IE}$ & 108.9 & 10.93 & 10 & 125 & 0.6 & 0.10 & 0.8 & 0.8 \\
\hline $1 / 15 / 2012$ 21:32:23 & 42.8607 & -111.1615 & 1.3 ML IE & 158.2 & 11.24 & 8 & 213 & 11.7 & 0.12 & 6.1 & 3.5 \\
\hline 1/16/2012 5:48:01 & 42.8300 & -111.2952 & 1.4 ML IE & 151.4 & 6.70 & 9 & 155 & 17.5 & 0.06 & 1.7 & 5.6 \\
\hline 1/16/2012 6:28:19 & 44.5540 & -112.4213 & $0.9 \mathrm{Mc} \mathrm{IE}$ & 104.7 & 2.04 & 5 & 134 & 4.9 & 0.05 & 6.9 & 9.1 \\
\hline 1/16/2012 14:07:59 & 43.3355 & -111.0342 & 1.2 ML IE & 145.7 & 11.08 & 9 & 176 & 15.1 & 0.03 & 0.9 & 2.4 \\
\hline 1/16/2012 15:27:20 & 42.8355 & -111.3085 & 1.0 ML IE & 150.1 & 5.03 & 5 & 260 & 18.7 & 0.05 & 2.8 & 9.9 \\
\hline 1/16/2012 16:35:58 & 44.6528 & -112.0322 & $1.7 \mathrm{Mc} \mathrm{IE}$ & 126.7 & 3.84 & 17 & 102 & 29.5 & 0.03 & 0.3 & 0.5 \\
\hline 1/16/2012 19:11:30 & 44.5680 & -114.0642 & 1.3 ML IE & 144.7 & 11.62 & 8 & 238 & 59.7 & 0.09 & 1.6 & 2.1 \\
\hline 1/17/2012 6:38:08 & 44.6692 & -112.1117 & $2.2 \mathrm{Mc} \mathrm{IE}$ & 125.5 & 11.27 & 21 & 105 & 24.0 & 0.04 & 0.4 & 1.0 \\
\hline 1/18/2012 21:22:05 & 42.9302 & -111.2080 & 1.0 ML IE & 150.8 & 13.41 & 6 & 124 & 17.5 & 0.02 & 0.9 & 2.6 \\
\hline $1 / 18 / 2012$ 22:02:03 & 42.9315 & -111.2097 & $0.8 \mathrm{ML} \mathrm{IE}$ & 150.6 & 11.84 & 4 & 198 & 17.3 & 0.02 & 1.2 & 3.0 \\
\hline 1/19/2012 0:10:09 & 42.8498 & -111.2370 & $1.5 \mathrm{ML} \mathrm{IE}$ & 153.9 & 10.99 & 9 & 175 & 14.6 & 0.06 & 0.9 & 2.4 \\
\hline 1/19/2012 17:32:02 & 42.8450 & -111.2422 & 1.1 Mc IE & 153.8 & 12.18 & 8 & 179 & 14.6 & 0.05 & 0.9 & 1.6 \\
\hline 1/20/2012 6:28:01 & 42.8975 & -111.5375 & 1.1 ML IE & 131.2 & 0.03 & 6 & 156 & 10.5 & 0.09 & 1.0 & 1.2 \\
\hline 1/20/2012 7:35:30 & 42.8975 & -111.5270 & $0.8 \mathrm{ML}$ IE & 131.9 & 0.02 & 5 & 284 & 9.7 & 0.04 & 1.9 & 0.8 \\
\hline 1/20/2012 11:10:59 & 44.2915 & -114.4710 & 2.1 Mc IE & 153.0 & 7.02 & 10 & 272 & 81.2 & 0.11 & 1.4 & 4.3 \\
\hline 1/21/2012 12:31:07 & 43.2320 & -110.9437 & 1.2 ML IE & 155.9 & 16.18 & 10 & 167 & 16.3 & 0.06 & 1.0 & 1.0 \\
\hline 1/23/2012 5:38:27 & 44.6248 & -112.1370 & $0.9 \mathrm{Mc} \mathrm{IE}$ & 120.1 & 15.58 & 6 & 207 & 20.7 & 0.06 & 2.0 & 1.1 \\
\hline $1 / 23 / 2012$ 14:49:24 & 44.9120 & -112.7657 & 1.8 ML IE & 140.4 & 7.01 & 9 & 156 & 11.4 & 0.03 & 1.5 & 6.3 \\
\hline $1 / 24 / 2012$ 17:24:31 & 44.5445 & -112.4460 & $0.8 \mathrm{ML} \mathrm{IE}$ & 103.1 & 1.14 & 5 & 180 & 6.8 & 0.02 & 3.1 & 8.4 \\
\hline $1 / 24 / 2012$ 17:24:56 & 44.5753 & -112.4088 & $0.4 \mathrm{Mc} \mathrm{IE}$ & 107.2 & 9.47 & 6 & 135 & 2.3 & 0.03 & 2.5 & 2.8 \\
\hline 1/25/2012 4:12:16 & 43.4550 & -111.0437 & $0.7 \mathrm{Mc} \mathrm{IE}$ & 142.1 & 0.25 & 7 & 240 & 8.5 & 0.03 & 1.2 & 1.2 \\
\hline 1/25/2012 15:37:54 & 44.9228 & -112.7322 & 2.2 ML IE & 141.7 & 3.03 & 11 & 150 & 14.0 & 0.02 & 1.4 & 3.2 \\
\hline 1/26/2012 0:19:18 & 44.3830 & -112.8462 & $1.2 \mathrm{Mc} \mathrm{IE}$ & 81.7 & 4.63 & 9 & 196 & 34.9 & 0.10 & 0.8 & 1.1 \\
\hline
\end{tabular}




\begin{tabular}{|c|c|c|c|c|c|c|c|c|c|c|c|}
\hline ORIGIN TIME & LAT N & LONG W & MAG-TYPE & DIST & Z & NO & GAP & DMIN & RMS & $\mathrm{ERH}$ & ERZ \\
\hline 1/28/2012 8:14:34 & 44.5930 & -112.4068 & 1.4 Mc IE & 109.1 & 10.55 & 12 & 96 & 1.0 & 0.09 & 0.9 & 0.7 \\
\hline 1/28/2012 8:14:43 & 44.5822 & -112.4018 & NM & 108.1 & 11.40 & 7 & 173 & 1.4 & 0.04 & 2.4 & 1.3 \\
\hline 1/29/2012 2:01:48 & 42.7673 & -111.4702 & $0.6 \mathrm{ML}$ IE & 145.0 & 2.47 & 5 & 281 & 19.4 & 0.11 & 4.4 & 15.1 \\
\hline 1/29/2012 11:02:29 & 42.8157 & -111.2760 & $0.9 \mathrm{Mc} \mathrm{IE}$ & 153.6 & 13.57 & 7 & 208 & 15.4 & 0.07 & 1.8 & 2.5 \\
\hline 1/30/2012 6:21:42 & 44.3767 & -114.0458 & $1.3 \mathrm{Mc} \mathrm{IE}$ & 129.5 & 6.44 & 10 & 223 & 51.6 & 0.15 & 1.3 & 4.2 \\
\hline 1/30/2012 14:57:47 & 44.2287 & -114.1098 & $2.6 \mathrm{Mc} \mathrm{MB}$ & 124.4 & 5.65 & 20 & 217 & 57.0 & 0.06 & 0.6 & 2.0 \\
\hline 1/30/2012 23:57:01 & 44.6158 & -112.0733 & $1.9 \mathrm{Mc} \mathrm{IE}$ & 121.5 & 12.90 & 19 & 94 & 25.6 & 0.05 & 0.3 & 0.7 \\
\hline 1/31/2012 8:07:30 & 44.5342 & -112.2653 & $0.4 \mathrm{ML}$ IE & 106.7 & 0.03 & 8 & 126 & 12.2 & 0.19 & 0.9 & 2.3 \\
\hline 1/31/2012 12:48:13 & 43.2378 & -111.0065 & $0.9 \mathrm{Mc} \mathrm{IE}$ & 150.9 & 2.73 & 8 & 147 & 18.7 & 0.11 & 0.9 & 14.7 \\
\hline 2/1/2012 4:46:41 & 43.7987 & -110.9593 & 1.0 ML IE & 147.8 & 6.71 & 11 & 140 & 11.0 & 0.08 & 0.8 & 1.9 \\
\hline 2/1/2012 5:13:29 & 44.5923 & -112.4110 & $0.5 \mathrm{ML}$ IE & 109.0 & 11.36 & 7 & 116 & 1.3 & 0.04 & 1.8 & 1.4 \\
\hline 2/1/2012 7:34:58 & 44.5930 & -112.3918 & $1.4 \mathrm{Mc} \mathrm{MB}$ & 109.5 & 11.03 & 15 & 124 & 0.2 & 0.06 & 0.6 & 0.3 \\
\hline 2/1/2012 11:48:17 & 42.9747 & -111.5038 & $1.5 \mathrm{Mc} \mathrm{IE}$ & 128.1 & 6.71 & 14 & 176 & 7.8 & 0.03 & 1.1 & 0.8 \\
\hline 2/1/2012 16:51:34 & 44.5945 & -112.6047 & 1.1 Mc MB & 106.0 & 2.14 & 6 & 126 & 16.7 & 0.04 & 4.8 & 11.5 \\
\hline 2/2/2012 1:10:59 & 44.1965 & -112.8828 & $1.3 \mathrm{Mc} \mathrm{IE}$ & 61.3 & 10.35 & 16 & 142 & 14.0 & 0.06 & 0.5 & 1.3 \\
\hline 2/2/2012 5:23:37 & 44.5132 & -111.1822 & 1.7 Mc IE & 160.1 & 16.52 & 15 & 162 & 35.9 & 0.07 & 0.5 & 0.7 \\
\hline 2/2/2012 9:38:04 & 43.3862 & -113.5618 & 1.6 ML IE & 69.4 & 11.00 & 13 & 166 & 8.8 & 0.08 & 0.7 & 1.2 \\
\hline 2/2/2012 12:38:42 & 44.7843 & -112.0197 & 1.0 Mc MB & 140.2 & 5.01 & 4 & 137 & 28.7 & 0.06 & 1.2 & 13.4 \\
\hline 2/3/2012 12:13:28 & 42.8068 & -111.2095 & $0.9 \mathrm{ML}$ IE & 158.5 & 11.85 & 6 & 194 & 10.1 & 0.04 & 1.2 & 2.3 \\
\hline 2/4/2012 5:22:40 & 42.8793 & -111.2583 & 1.4 Mc IE & 150.5 & 10.53 & 14 & 103 & 14.8 & 0.05 & 0.5 & 1.0 \\
\hline 2/4/2012 5:29:13 & 42.8877 & -111.2465 & 1.7 ML IE & 150.8 & 9.66 & 17 & 106 & 15.4 & 0.06 & 0.4 & 1.3 \\
\hline 2/4/2012 5:29:29 & 42.8870 & -111.2527 & 1.4 ML IE & 150.4 & 11.25 & 6 & 156 & 14.9 & 0.05 & 0.9 & 3.7 \\
\hline 2/4/2012 7:23:37 & 43.7232 & -110.9278 & 2.8 ML US & 149.7 & 4.51 & 28 & 95 & 12.4 & 0.08 & 0.4 & 2.9 \\
\hline 2/4/2012 7:35:20 & 43.7213 & -110.9228 & $0.8 \mathrm{Mc} \mathrm{IE}$ & 150.1 & 6.44 & 8 & 134 & 12.5 & 0.06 & 0.6 & 3.3 \\
\hline 2/4/2012 10:44:14 & 42.9457 & -111.4845 & $0.8 \mathrm{ML}$ IE & 131.3 & 0.02 & 7 & 273 & 5.2 & 0.14 & 2.8 & 1.4 \\
\hline 2/5/2012 7:10:42 & 43.7252 & -110.9233 & 1.4 Mc IE & 150.1 & 5.27 & 13 & 118 & 12.8 & 0.08 & 0.4 & 3.8 \\
\hline 2/5/2012 8:03:52 & 43.5463 & -111.2050 & 1.2 ML IE & 127.9 & 6.52 & 10 & 263 & 17.6 & 0.09 & 1.0 & 3.8 \\
\hline 2/6/2012 1:41:47 & 44.6550 & -112.0988 & $2.4 \mathrm{Mc} \mathrm{IE}$ & 124.5 & 9.56 & 20 & 102 & 24.4 & 0.12 & 0.4 & 2.2 \\
\hline 2/6/2012 4:10:50 & 43.7690 & -110.8370 & $0.4 \mathrm{Mc} \mathrm{IE}$ & 157.3 & 8.04 & 7 & 162 & 16.4 & 0.05 & 0.9 & 3.5 \\
\hline 2/7/2012 3:09:09 & 42.9265 & -111.4203 & $1.5 \mathrm{Mc} \mathrm{IE}$ & 136.7 & 2.01 & 13 & 157 & 1.3 & 0.07 & 1.1 & 1.0 \\
\hline 2/7/2012 3:12:03 & 42.9133 & -111.4767 & $0.8 \mathrm{ML}$ IE & 134.0 & 1.04 & 10 & 267 & 5.3 & 0.05 & 1.5 & 0.8 \\
\hline 2/7/2012 15:16:54 & 42.9053 & -111.4872 & $0.9 \mathrm{ML}$ IE & 133.9 & 0.18 & 4 & 274 & 6.5 & 0.09 & 10.1 & 5.8 \\
\hline 2/7/2012 15:31:32 & 42.9382 & -111.3910 & 1.4 ML IE & 137.9 & 0.02 & 13 & 97 & 2.5 & 0.08 & 1.0 & 2.4 \\
\hline 2/7/2012 16:28:14 & 42.9255 & -111.4367 & 1.2 ML IE & 135.7 & 3.07 & 10 & 144 & 1.9 & 0.08 & 1.1 & 0.7 \\
\hline 2/7/2012 16:53:07 & 44.6190 & -112.0737 & $0.9 \mathrm{ML}$ IE & 121.8 & 13.15 & 10 & 138 & 25.6 & 0.02 & 0.6 & 2.0 \\
\hline 2/8/2012 4:16:22 & 44.6225 & -112.0653 & 1.7 Mc IE & 122.5 & 9.24 & 17 & 95 & 26.3 & 0.06 & 0.3 & 1.8 \\
\hline 2/8/2012 10:28:09 & 44.4422 & -112.8463 & $0.9 \mathrm{Mc} \mathrm{IE}$ & 88.3 & 10.00 & 8 & 107 & 39.7 & 0.10 & 0.8 & 13.1 \\
\hline 2/9/2012 8:55:52 & 44.6713 & -114.1955 & 1.6 Mc IE & 160.2 & 8.95 & 7 & 294 & 74.5 & 0.06 & 11.2 & 3.0 \\
\hline 2/9/2012 20:00:26 & 43.4640 & -111.0123 & $0.9 \mathrm{Mc} \mathrm{IE}$ & 144.5 & 6.63 & 9 & 227 & 5.8 & 0.10 & 1.5 & 1.1 \\
\hline 2/9/2012 20:03:05 & 43.2673 & -111.2302 & 1.2 ML IE & 132.6 & 12.42 & 13 & 172 & 26.4 & 0.08 & 0.9 & 3.4 \\
\hline 2/10/2012 18:47:35 & 42.7187 & -111.7435 & 1.1 ML IE & 133.7 & 9.16 & 8 & 106 & 35.9 & 0.07 & 0.8 & 5.5 \\
\hline 2/11/2012 2:46:35 & 42.7332 & -111.7228 & $0.8 \mathrm{ML}$ IE & 133.5 & 4.98 & 5 & 111 & 45.8 & 0.12 & 0.9 & 15.0 \\
\hline 2/11/2012 4:50:10 & 42.9667 & -111.6103 & $0.7 \mathrm{Mc} \mathrm{IE}$ & 121.7 & 3.81 & 7 & 284 & 15.7 & 0.05 & 5.8 & 9.4 \\
\hline 2/11/2012 19:19:04 & 44.4718 & -112.9017 & 1.6 Mc IE & 91.9 & 6.63 & 10 & 119 & 39.8 & 0.09 & 0.6 & 13.1 \\
\hline 2/11/2012 19:31:06 & 44.4658 & -112.8953 & 1.3 Mc IE & 91.2 & 8.83 & 9 & 117 & 40.4 & 0.06 & 0.6 & 12.9 \\
\hline 2/12/2012 2:29:48 & 43.5108 & -111.1110 & $0.0 \mathrm{Mc} \mathrm{IE}$ & 135.9 & 4.00 & 5 & 249 & 13.2 & 0.08 & 3.2 & 11.3 \\
\hline 2/12/2012 6:06:32 & 44.2383 & -114.0323 & 1.2 ML IE & 119.7 & 5.34 & 10 & 212 & 50.7 & 0.12 & 1.6 & 6.1 \\
\hline 2/12/2012 6:59:17 & 43.2117 & -110.9255 & 1.0 Mc IE & 158.0 & 3.37 & 6 & 215 & 17.8 & 0.12 & 1.7 & 13.4 \\
\hline 2/13/2012 1:10:46 & 44.6375 & -112.5118 & $1.5 \mathrm{Mc} \mathrm{IE}$ & 112.0 & 15.01 & 7 & 132 & 10.5 & 0.03 & 1.0 & 1.5 \\
\hline
\end{tabular}




\begin{tabular}{|c|c|c|c|c|c|c|c|c|c|c|c|}
\hline ORIGIN TIME & LAT N & LONG W & MAG-TYPE & DIST & Z & NO & GAP & DMIN & RMS & $\mathrm{ERH}$ & $\mathrm{ERZ}$ \\
\hline 2/13/2012 12:27:17 & 42.6453 & -111.6935 & 1.1 ML IE & 142.6 & 6.33 & 10 & 114 & 39.4 & 0.10 & 0.6 & 12.3 \\
\hline 2/13/2012 15:11:32 & 44.1893 & -114.3920 & $2.1 \mathrm{Mc} \mathrm{IE}$ & 142.4 & 11.18 & 8 & 258 & 69.7 & 0.11 & 1.2 & 4.4 \\
\hline 2/13/2012 21:04:58 & 44.6982 & -111.8515 & $1.9 \mathrm{Mc} \mathrm{MB}$ & 138.4 & 5.05 & 11 & 114 & 15.1 & 0.02 & 1.1 & 2.0 \\
\hline 2/14/2012 7:22:27 & 44.7160 & -111.8445 & 1.6 Mc MB & 140.3 & 9.43 & 9 & 122 & 14.3 & 0.05 & 1.2 & 2.4 \\
\hline 2/14/2012 18:40:34 & 43.8493 & -113.6173 & $0.7 \mathrm{Mc} \mathrm{IE}$ & 70.7 & 6.20 & 8 & 201 & 16.0 & 0.05 & 1.6 & 1.2 \\
\hline 2/15/2012 3:03:08 & 44.4803 & -113.9572 & $0.9 \mathrm{ML} \mathrm{IE}$ & 131.8 & 6.75 & 7 & 225 & 73.4 & 0.10 & 1.0 & 4.2 \\
\hline 2/15/2012 16:22:07 & 44.4672 & -112.8970 & 1.2 ML IE & 91.4 & 2.17 & 5 & 152 & 40.2 & 0.01 & 0.7 & 2.3 \\
\hline 2/15/2012 18:16:14 & 44.4773 & -112.8797 & 1.2 Mc IE & 92.4 & 7.58 & 5 & 156 & 39.0 & 0.12 & 0.8 & 15.7 \\
\hline 2/16/2012 9:09:52 & 43.3128 & -111.5350 & $0.2 \mathrm{ML} \mathrm{IE}$ & 107.7 & 12.29 & 8 & 241 & 31.8 & 0.06 & 0.9 & 2.0 \\
\hline 2/16/2012 9:33:09 & 43.3170 & -111.5763 & 1.0 ML IE & 104.4 & 3.23 & 11 & 138 & 33.7 & 0.16 & 1.4 & 17.6 \\
\hline 2/17/2012 0:42:05 & 44.4783 & -112.6167 & 1.4 Mc IE & 93.1 & 7.72 & 6 & 160 & 21.8 & 0.04 & 1.3 & 12.9 \\
\hline 2/17/2012 5:16:39 & 42.5487 & -111.8847 & $0.7 \mathrm{Mc} \mathrm{IE}$ & 142.7 & 5.00 & 4 & 116 & 48.7 & 0.02 & 1.1 & 12.5 \\
\hline 2/17/2012 12:39:30 & 43.2312 & -110.9215 & $0.8 \mathrm{Mc} \mathrm{IE}$ & 157.7 & 1.96 & 10 & 165 & 15.6 & 0.12 & 1.1 & 1.6 \\
\hline 2/17/2012 21:22:00 & 43.3568 & -111.2062 & $0.5 \mathrm{ML} \mathrm{IE}$ & 131.6 & 5.08 & 6 & 291 & 25.5 & 0.11 & 2.0 & 13.9 \\
\hline 2/18/2012 1:10:40 & 43.3597 & -111.0793 & $0.9 \mathrm{ML} \mathrm{IE}$ & 141.5 & 15.19 & 6 & 332 & 17.8 & 0.05 & 2.8 & 1.8 \\
\hline 2/18/2012 2:41:49 & 43.3898 & -111.1360 & 1.0 ML IE & 136.2 & 0.11 & 10 & 181 & 18.7 & 0.12 & 1.0 & 3.2 \\
\hline 2/18/2012 21:24:32 & 43.2282 & -110.9233 & 1.0 Mc IE & 157.6 & 6.82 & 7 & 212 & 16.0 & 0.08 & 1.4 & 3.8 \\
\hline 2/19/2012 22:42:57 & 43.0800 & -111.4587 & 1.8 Mc IE & 124.6 & 5.53 & 14 & 129 & 7.8 & 0.09 & 0.7 & 1.0 \\
\hline 2/19/2012 23:02:17 & 43.0837 & -111.4652 & 2.1 ML IE & 124.0 & 5.71 & 22 & 91 & 8.4 & 0.14 & 0.6 & 1.5 \\
\hline 2/20/2012 4:17:39 & 44.5845 & -112.4197 & 1.7 Mc IE & 108.0 & 10.10 & 17 & 73 & 2.2 & 0.10 & 0.4 & 0.5 \\
\hline 2/20/2012 11:20:14 & 43.1358 & -111.1902 & $0.7 \mathrm{ML} \mathrm{IE}$ & 141.1 & 3.58 & 8 & 134 & 17.3 & 0.11 & 0.9 & 11.2 \\
\hline 2/20/2012 11:41:55 & 44.6658 & -112.1100 & $1.5 \mathrm{Mc} \mathrm{IE}$ & 125.2 & 12.46 & 12 & 104 & 24.0 & 0.06 & 0.5 & 1.7 \\
\hline 2/20/2012 22:53:43 & 42.6150 & -111.4088 & 1.2 Mc IE & 160.5 & 5.86 & 8 & 123 & 30.3 & 0.04 & 0.8 & 6.9 \\
\hline 2/20/2012 23:38:26 & 42.8778 & -111.4452 & $2.1 \mathrm{Mc}$ IE & 138.4 & 0.03 & 13 & 157 & 7.0 & 0.17 & 0.9 & 1.1 \\
\hline 2/21/2012 15:01:21 & 43.0795 & -111.4293 & 1.4 ML IE & 126.7 & 7.20 & 9 & 210 & 5.6 & 0.04 & 1.6 & 1.0 \\
\hline 2/21/2012 18:39:13 & 43.1443 & -111.4760 & NM & 119.9 & 4.60 & 3 & 330 & 13.3 & 0.18 & 5.4 & 7.8 \\
\hline 2/21/2012 18:39:17 & 43.1475 & -111.4688 & 1.4 ML IE & 120.2 & 2.49 & 4 & 332 & 13.2 & 0.03 & 3.1 & 10.7 \\
\hline 2/22/2012 1:41:14 & 44.6493 & -112.0025 & 1.0 ML IE & 127.5 & 10.24 & 5 & 172 & 28.2 & 0.04 & 1.4 & 7.9 \\
\hline 2/22/2012 21:02:49 & 44.3115 & -113.1712 & 2.1 ML IE & 79.9 & 5.83 & 21 & 111 & 18.7 & 0.08 & 0.4 & 1.0 \\
\hline 2/23/2012 9:59:01 & 44.6177 & -112.3988 & 1.0 Mc IE & 112.0 & 13.80 & 5 & 299 & 2.7 & 0.01 & 4.9 & 0.9 \\
\hline 2/23/2012 14:06:35 & 43.3683 & -110.8545 & $0.2 \mathrm{ML} \mathrm{IE}$ & 159.0 & 8.28 & 8 & 169 & 0.7 & 0.10 & 0.9 & 1.5 \\
\hline $2 / 25 / 2012$ 0:45:51 & 43.0702 & -111.4373 & $0.8 \mathrm{Mc}$ IE & 126.7 & 1.58 & 6 & 212 & 5.8 & 0.03 & 2.0 & 1.1 \\
\hline 2/26/2012 4:31:35 & 43.2730 & -111.2540 & $0.6 \mathrm{ML} \mathrm{IE}$ & 130.6 & 5.01 & 6 & 182 & 26.2 & 0.06 & 1.0 & 10.4 \\
\hline 2/26/2012 8:27:46 & 43.3128 & -110.9837 & $0.8 \mathrm{ML} \mathrm{IE}$ & 150.3 & 2.12 & 9 & 166 & 12.0 & 0.19 & 0.8 & 20.2 \\
\hline 2/26/2012 8:27:53 & 43.3192 & -110.9903 & $0.6 \mathrm{ML} \mathrm{IE}$ & 149.6 & 6.18 & 6 & 180 & 12.2 & 0.05 & 0.8 & 4.1 \\
\hline 2/26/2012 8:33:27 & 43.3313 & -110.9693 & $0.9 \mathrm{ML}$ IE & 150.9 & 2.49 & 9 & 163 & 10.1 & 0.14 & 1.0 & 14.5 \\
\hline 2/26/2012 8:33:44 & 43.3100 & -110.9690 & $0.8 \mathrm{ML} \mathrm{IE}$ & 151.5 & 3.58 & 8 & 162 & 11.1 & 0.07 & 0.6 & 5.1 \\
\hline 2/27/2012 17:19:59 & 42.9472 & -111.5017 & 1.0 ML IE & 130.1 & 0.02 & 5 & 281 & 6.6 & 0.06 & 2.8 & 0.9 \\
\hline 2/27/2012 20:04:20 & 44.5700 & -112.0493 & $0.9 \mathrm{Mc} \mathrm{IE}$ & 118.0 & 6.48 & 4 & 155 & 27.5 & 0.05 & 2.0 & 11.5 \\
\hline 3/1/2012 1:36:47 & 42.8717 & -111.5397 & 1.0 ML IE & 133.0 & 2.18 & 6 & 277 & 12.1 & 0.07 & 1.6 & 13.5 \\
\hline 3/5/2012 5:18:02 & 44.3493 & -112.8648 & 2.1 Mc IE & 78.1 & 8.44 & 17 & 96 & 31.0 & 0.12 & 0.4 & 7.0 \\
\hline $3 / 5 / 2012$ 10:52:20 & 44.2635 & -114.0960 & 1.0 ML IE & 125.5 & 6.98 & 7 & 246 & 55.4 & 0.07 & 1.2 & 5.1 \\
\hline 3/5/2012 11:46:35 & 43.2828 & -110.9018 & 1.2 Mc IE & 157.5 & 11.34 & 7 & 163 & 9.7 & 0.08 & 1.5 & 1.6 \\
\hline 3/6/2012 19:30:09 & 43.3138 & -111.5365 & $0.6 \mathrm{ML} \mathrm{IE}$ & 107.5 & 5.08 & 5 & 254 & 31.9 & 0.25 & 3.7 & 21.8 \\
\hline 3/7/2012 5:02:37 & 43.8423 & -110.9295 & $0.1 \mathrm{Mc}$ IE & 150.7 & 8.15 & 6 & 190 & 6.1 & 0.05 & 3.5 & 2.1 \\
\hline 3/7/2012 9:44:22 & 43.8505 & -111.0413 & $0.2 \mathrm{ML}$ IE & 142.0 & 3.22 & 7 & 240 & 9.7 & 0.07 & 1.3 & 8.2 \\
\hline $3 / 7 / 2012$ 12:26:55 & 44.9107 & -111.8593 & 1.2 Mc MB & 158.4 & 5.17 & 9 & 190 & 25.3 & 0.05 & 0.6 & 12.9 \\
\hline 3/7/2012 12:27:10 & 44.9132 & -111.8705 & 1.3 ML IE & 158.3 & 9.37 & 9 & 189 & 26.0 & 0.00 & 0.6 & 1.7 \\
\hline 3/7/2012 22:59:30 & 44.3417 & -112.5537 & $0.6 \mathrm{ML}$ IE & 79.1 & 5.51 & 4 & 184 & 18.9 & 0.04 & 3.7 & 8.5 \\
\hline
\end{tabular}




\begin{tabular}{|c|c|c|c|c|c|c|c|c|c|c|c|}
\hline ORIGIN TIME & LAT N & LONG W & MAG-TYPE & DIST & Z & NO & GAP & DMIN & RMS & $\mathrm{ERH}$ & ERZ \\
\hline 3/9/2012 0:49:35 & 43.3018 & -111.0915 & $0.5 \mathrm{Mc} \mathrm{IE}$ & 142.2 & 5.15 & 8 & 297 & 20.6 & 0.20 & 1.8 & 12.3 \\
\hline 3/9/2012 1:08:34 & 42.9092 & -111.2670 & 3.0 Mc MB & 148.1 & 11.13 & 27 & 105 & 13.0 & 0.20 & 0.4 & 1.1 \\
\hline 3/9/2012 20:23:42 & 42.8810 & -111.3002 & $0.8 \mathrm{ML} \mathrm{IE}$ & 147.6 & 10.90 & 7 & 175 & 11.8 & 0.05 & 1.4 & 2.9 \\
\hline $3 / 9 / 2012$ 20:47:56 & 42.8890 & -111.2923 & 1.1 Mc IE & 147.6 & 12.02 & 10 & 167 & 11.9 & 0.09 & 1.3 & 2.3 \\
\hline $3 / 9 / 2012$ 22:17:38 & 42.8945 & -111.2725 & 1.0 ML IE & 148.6 & 9.71 & 12 & 157 & 13.1 & 0.06 & 0.6 & 2.0 \\
\hline 3/9/2012 23:54:56 & 43.6432 & -111.0438 & $0.8 \mathrm{Mc} \mathrm{IE}$ & 140.3 & 11.99 & 7 & 197 & 1.5 & 0.02 & 2.0 & 0.9 \\
\hline 3/10/2012 15:54:12 & 42.8763 & -111.2962 & $0.4 \mathrm{ML} \mathrm{IE}$ & 148.2 & 11.32 & 4 & 177 & 12.3 & 0.01 & 2.4 & 3.9 \\
\hline 3/10/2012 17:12:11 & 42.8975 & -111.2652 & 1.9 Mc IE & 148.9 & 9.35 & 19 & 132 & 13.5 & 0.08 & 0.7 & 2.2 \\
\hline 3/11/2012 5:13:36 & 43.1315 & -110.9655 & $0.9 \mathrm{Mc} \mathrm{IE}$ & 158.1 & 2.92 & 11 & 168 & 27.3 & 0.04 & 0.8 & 12.0 \\
\hline 3/13/2012 9:09:51 & 42.8977 & -111.2793 & 1.8 ML IE & 148.0 & 11.76 & 16 & 101 & 12.4 & 0.07 & 0.4 & 0.9 \\
\hline 3/14/2012 17:29:14 & 42.8708 & -111.3018 & $0.8 \mathrm{ML} \mathrm{IE}$ & 148.2 & 13.89 & 9 & 183 & 12.3 & 0.05 & 1.4 & 2.0 \\
\hline 3/15/2012 18:44:13 & 44.4948 & -114.2947 & 1.3 ML IE & 153.2 & 3.09 & 5 & 246 & 73.8 & 0.04 & 2.1 & 4.3 \\
\hline 3/16/2012 15:02:27 & 44.7223 & -112.5163 & $1.6 \mathrm{Mc} \mathrm{IE}$ & 121.2 & 3.96 & 9 & 210 & 17.3 & 0.06 & 8.0 & 7.7 \\
\hline 3/16/2012 17:23:55 & 42.8945 & -111.2797 & 1.8 ML IE & 148.1 & 11.30 & 12 & 159 & 12.6 & 0.07 & 0.8 & 2.0 \\
\hline $3 / 17 / 2012$ 2:34:51 & 43.6560 & -110.9212 & $0.2 \mathrm{ML} \mathrm{IE}$ & 150.1 & 11.32 & 6 & 103 & 8.7 & 0.18 & 0.9 & 2.7 \\
\hline 3/17/2012 4:59:43 & 44.4040 & -111.1090 & $0.6 \mathrm{ML} \mathrm{IE}$ & 158.2 & 13.97 & 7 & 257 & 24.5 & 0.06 & 3.2 & 1.2 \\
\hline 3/17/2012 9:54:58 & 43.1180 & -110.9502 & $1.0 \mathrm{Mc} \mathrm{IE}$ & 159.8 & 12.23 & 10 & 172 & 28.3 & 0.08 & 0.9 & 2.3 \\
\hline 3/17/2012 11:06:38 & 43.2840 & -111.4105 & $0.0 \mathrm{ML} \mathrm{IE}$ & 118.2 & 5.15 & 6 & 246 & 25.8 & 0.15 & 2.4 & 14.6 \\
\hline 3/17/2012 14:20:20 & 43.8208 & -114.7160 & 1.3 Mc IE & 156.8 & 5.92 & 9 & 208 & 98.9 & 0.11 & 1.5 & 4.8 \\
\hline 3/18/2012 22:33:19 & 42.9008 & -111.2697 & $2.4 \mathrm{Mc} \mathrm{IE}$ & 148.4 & 6.29 & 18 & 103 & 13.1 & 0.07 & 0.4 & 1.9 \\
\hline 3/19/2012 6:58:42 & 44.3750 & -114.4628 & 1.1 Mc IE & 156.9 & 4.96 & 8 & 250 & 84.6 & 0.06 & 1.3 & 3.9 \\
\hline 3/19/2012 12:07:57 & 42.8965 & -111.2817 & 1.2 ML IE & 147.9 & 11.18 & 10 & 135 & 12.3 & 0.08 & 0.7 & 1.8 \\
\hline 3/20/2012 3:42:11 & 44.1477 & -113.1010 & $0.1 \mathrm{ML} \mathrm{IE}$ & 61.0 & 6.67 & 6 & 153 & 24.7 & 0.04 & 0.6 & 13.0 \\
\hline 3/20/2012 20:16:29 & 43.7990 & -114.7275 & 1.6 ML IE & 157.5 & 2.80 & 12 & 176 & 36.9 & 0.03 & 1.3 & 2.1 \\
\hline 3/20/2012 23:48:03 & 43.3432 & -110.9587 & $0.8 \mathrm{ML} \mathrm{IE}$ & 151.4 & 3.85 & 5 & 275 & 8.9 & 0.06 & 2.9 & 10.2 \\
\hline 3/20/2012 23:48:25 & 43.3693 & -110.9668 & $0.4 \mathrm{ML} \mathrm{IE}$ & 150.1 & 3.76 & 5 & 257 & 9.3 & 0.03 & 3.8 & 12.1 \\
\hline 3/21/2012 1:55:40 & 43.4835 & -110.8073 & $0.8 \mathrm{ML} \mathrm{IE}$ & 160.6 & 2.06 & 9 & 147 & 11.6 & 0.08 & 0.6 & 14.2 \\
\hline 3/21/2012 22:49:01 & 44.2027 & -114.5825 & 1.4 ML IE & 157.0 & 0.05 & 15 & 205 & 72.5 & 0.04 & 1.3 & 1.8 \\
\hline 3/22/2012 23:08:30 & 42.9003 & -111.2798 & 1.3 ML IE & 147.8 & 10.29 & 9 & 155 & 12.3 & 0.05 & 0.9 & 2.6 \\
\hline 3/22/2012 23:30:13 & 43.6665 & -111.1277 & $0.5 \mathrm{ML} \mathrm{IE}$ & 133.5 & 1.51 & 5 & 210 & 8.7 & 0.05 & 1.5 & 4.4 \\
\hline 3/23/2012 15:44:40 & 43.7867 & -114.7715 & 1.3 Mc IE & 160.9 & 5.57 & 9 & 311 & 38.6 & 0.02 & 4.1 & 8.3 \\
\hline $3 / 24 / 20125: 53: 12$ & 43.1858 & -111.0220 & $0.2 \mathrm{ML} \mathrm{IE}$ & 151.6 & 13.06 & 5 & 208 & 24.0 & 0.01 & 2.0 & 3.2 \\
\hline 3/24/2012 9:36:49 & 44.4637 & -112.7465 & $0.6 \mathrm{Mc} \mathrm{IE}$ & 90.6 & 6.94 & 9 & 96 & 31.5 & 0.14 & 0.6 & 16.8 \\
\hline 3/26/2012 13:55:26 & 43.0407 & -111.4025 & $0.9 \mathrm{ML}$ IE & 130.8 & 3.93 & 9 & 193 & 3.0 & 0.04 & 0.9 & 0.7 \\
\hline 3/28/2012 3:43:47 & 44.6237 & -112.1250 & 1.3 Mc MB & 120.4 & 8.80 & 16 & 95 & 21.6 & 0.07 & 0.4 & 1.9 \\
\hline 3/28/2012 9:39:08 & 43.7063 & -111.0300 & $0.3 \mathrm{Mc}$ IE & 141.4 & 3.56 & 9 & 170 & 7.6 & 0.04 & 0.7 & 3.2 \\
\hline 3/28/2012 16:16:52 & 42.6860 & -111.7098 & $0.8 \mathrm{Mc}$ IE & 138.2 & 4.46 & 6 & 212 & 49.4 & 0.06 & 0.9 & 6.6 \\
\hline 3/29/2012 1:03:38 & 43.3258 & -110.9023 & 1.4 ML IE & 156.3 & 3.90 & 15 & 150 & 5.8 & 0.10 & 0.5 & 1.7 \\
\hline 3/29/2012 4:11:17 & 42.7817 & -111.3198 & $0.7 \mathrm{ML} \mathrm{IE}$ & 153.1 & 3.54 & 4 & 258 & 18.1 & 0.02 & 2.1 & 9.2 \\
\hline 3/29/2012 4:51:59 & 43.8503 & -110.8308 & $0.6 \mathrm{ML} \mathrm{IE}$ & 158.7 & 6.08 & 7 & 181 & 10.1 & 0.05 & 0.8 & 3.4 \\
\hline 3/30/2012 5:17:00 & 42.9195 & -111.3512 & $0.4 \mathrm{ML} \mathrm{IE}$ & 141.8 & 3.73 & 7 & 161 & 6.1 & 0.06 & 1.4 & 5.4 \\
\hline 3/30/2012 6:05:02 & 43.4675 & -110.8993 & $0.0 \mathrm{Mc} \mathrm{IE}$ & 153.5 & 3.83 & 5 & 189 & 4.9 & 0.04 & 9.0 & 8.7 \\
\hline $3 / 30 / 2012$ 9:26:46 & 44.8297 & -112.5393 & 1.3 Mc MB & 132.7 & 12.68 & 11 & 160 & 24.5 & 0.05 & 0.5 & 0.8 \\
\hline 3/31/2012 9:34:52 & 43.7713 & -111.0135 & $0.6 \mathrm{Mc} \mathrm{IE}$ & 143.2 & 2.50 & 9 & 159 & 14.8 & 0.09 & 0.8 & 11.5 \\
\hline 3/31/2012 20:03:14 & 43.2472 & -110.9098 & $0.6 \mathrm{ML} \mathrm{IE}$ & 158.0 & 2.03 & 9 & 166 & 13.6 & 0.08 & 0.9 & 14.2 \\
\hline 4/1/2012 18:25:31 & 44.2095 & -112.5323 & 1.3 Mc IE & 65.4 & 11.23 & 14 & 143 & 17.4 & 0.08 & 0.6 & 1.1 \\
\hline 4/2/2012 7:58:42 & 42.5723 & -111.4803 & $2.0 \mathrm{Mc} \mathrm{IE}$ & 160.0 & 10.55 & 19 & 108 & 37.8 & 0.02 & 0.6 & 1.2 \\
\hline 4/2/2012 9:42:25 & 42.5915 & -111.4510 & $0.9 \mathrm{ML}$ IE & 160.0 & 4.90 & 8 & 167 & 34.6 & 0.07 & 2.3 & 10.0 \\
\hline 4/2/2012 10:41:44 & 44.6357 & -112.0417 & 1.1 Mc MB & 124.7 & 6.69 & 6 & 151 & 28.4 & 0.07 & 0.8 & 12.4 \\
\hline
\end{tabular}




\begin{tabular}{|c|c|c|c|c|c|c|c|c|c|c|c|}
\hline ORIGIN TIME & LAT N & LONG W & MAG-TYPE & DIST & Z & NO & GAP & DMIN & RMS & $\mathrm{ERH}$ & $\mathrm{ERZ}$ \\
\hline 4/3/2012 5:03:24 & 43.7732 & -110.8408 & $0.0 \mathrm{ML}$ IE & 157.1 & 8.26 & 7 & 161 & 15.9 & 0.03 & 0.6 & 3.1 \\
\hline 4/4/2012 17:54:29 & 42.7615 & -111.3387 & 1.9 ML IE & 153.4 & 2.28 & 14 & 122 & 19.5 & 0.06 & 0.9 & 11.6 \\
\hline 4/4/2012 18:02:07 & 42.7763 & -111.2822 & 1.3 ML IE & 155.9 & 10.35 & 12 & 137 & 14.9 & 0.03 & 0.6 & 1.0 \\
\hline 4/4/2012 18:06:53 & 42.7108 & -111.3603 & $0.6 \mathrm{ML} \mathrm{IE}$ & 155.8 & 4.97 & 6 & 285 & 22.1 & 0.05 & 2.3 & 9.6 \\
\hline 4/4/2012 18:22:56 & 42.7643 & -111.3335 & 3.2 ML IE & 153.5 & 9.94 & 29 & 85 & 19.1 & 0.06 & 0.5 & 0.7 \\
\hline 4/5/2012 14:09:02 & 44.1185 & -113.9705 & $0.9 \mathrm{Mc} \mathrm{IE}$ & 108.7 & 8.82 & 11 & 198 & 46.6 & 0.05 & 0.9 & 4.0 \\
\hline 4/7/2012 0:09:53 & 43.5158 & -110.9750 & $0.2 \mathrm{ML} \mathrm{IE}$ & 146.7 & 9.04 & 7 & 194 & 3.5 & 0.03 & 1.0 & 1.7 \\
\hline 4/7/2012 1:14:22 & 43.8085 & -111.2177 & 1.1 ML IE & 127.3 & 11.72 & 10 & 214 & 24.4 & 0.05 & 1.0 & 2.2 \\
\hline 4/8/2012 21:33:30 & 44.6568 & -112.5057 & $0.5 \mathrm{ML}$ IE & 114.2 & 2.03 & 7 & 136 & 11.3 & 0.02 & 0.6 & 0.9 \\
\hline 4/9/2012 0:10:28 & 43.2922 & -111.3785 & $0.5 \mathrm{Mc} \mathrm{IE}$ & 120.4 & 2.50 & 9 & 190 & 26.5 & 0.10 & 1.0 & 14.9 \\
\hline 4/9/2012 0:15:52 & 43.2918 & -111.3885 & $0.5 \mathrm{Mc} \mathrm{IE}$ & 119.6 & 2.49 & 8 & 212 & 26.5 & 0.20 & 1.3 & 20.4 \\
\hline 4/9/2012 10:50:22 & 44.6813 & -113.2390 & 1.3 Mc MB & 120.4 & 7.59 & 8 & 224 & 34.9 & 0.07 & 1.2 & 12.5 \\
\hline 4/9/2012 15:52:48 & 42.8933 & -111.2718 & $0.6 \mathrm{ML} \mathrm{IE}$ & 148.7 & 2.44 & 10 & 158 & 13.2 & 0.09 & 0.5 & 14.0 \\
\hline 4/10/2012 0:05:35 & 42.5877 & -111.5010 & 1.4 Mc IE & 157.6 & 9.77 & 13 & 104 & 38.3 & 0.09 & 0.5 & 2.3 \\
\hline 4/10/2012 0:09:54 & 42.5967 & -111.4842 & 1.3 ML IE & 157.8 & 8.26 & 13 & 104 & 36.6 & 0.12 & 0.6 & 3.9 \\
\hline 4/10/2012 0:55:25 & 42.5783 & -111.5078 & 1.5 ML IE & 158.0 & 2.35 & 15 & 134 & 39.3 & 0.06 & 0.6 & 12.4 \\
\hline 4/11/2012 22:04:11 & 43.7057 & -111.0392 & $0.4 \mathrm{ML} \mathrm{IE}$ & 140.7 & 5.43 & 5 & 208 & 7.6 & 0.01 & 1.9 & 4.4 \\
\hline 4/12/2012 12:11:12 & 42.7022 & -111.6232 & $0.7 \mathrm{ML} \mathrm{IE}$ & 141.4 & 5.00 & 8 & 192 & 30.9 & 0.04 & 0.7 & 10.9 \\
\hline 4/13/2012 10:39:49 & 44.6885 & -112.4990 & $1.5 \mathrm{Mc} \mathrm{MB}$ & 117.7 & 14.58 & 12 & 90 & 13.4 & 0.05 & 0.7 & 0.9 \\
\hline $4 / 14 / 2012$ 4:30:59 & 42.6160 & -111.6665 & $1.3 \mathrm{Mc} \mathrm{IE}$ & 146.5 & 4.05 & 12 & 120 & 49.3 & 0.10 & 0.6 & 14.1 \\
\hline 4/14/2012 7:37:42 & 42.9617 & -111.4552 & $0.7 \mathrm{ML} \mathrm{IE}$ & 132.1 & 0.17 & 10 & 130 & 3.8 & 0.06 & 0.8 & 0.7 \\
\hline 4/14/2012 10:01:56 & 44.0148 & -114.6225 & 1.6 Mc IE & 153.4 & 6.83 & 12 & 270 & 53.2 & 0.09 & 2.0 & 4.2 \\
\hline 4/14/2012 10:57:28 & 42.8985 & -111.2707 & 1.0 ML IE & 148.5 & 4.80 & 10 & 154 & 13.1 & 0.08 & 1.1 & 8.3 \\
\hline 4/14/2012 11:53:48 & 43.1968 & -111.4865 & $0.6 \mathrm{ML} \mathrm{IE}$ & 116.4 & 6.45 & 6 & 263 & 18.5 & 0.01 & 1.8 & 4.6 \\
\hline 4/14/2012 17:41:20 & 42.9128 & -111.5718 & $0.7 \mathrm{ML} \mathrm{IE}$ & 128.0 & 2.86 & 5 & 294 & 12.6 & 0.08 & 2.2 & 11.0 \\
\hline 4/14/2012 19:58:11 & 42.8830 & -111.6753 & 1.9 ML IE & 123.9 & 3.84 & 15 & 164 & 21.6 & 0.06 & 0.5 & 4.9 \\
\hline 4/14/2012 20:23:12 & 42.8767 & -111.6303 & 1.7 ML IE & 127.1 & 6.66 & 13 & 116 & 18.4 & 0.05 & 0.6 & 2.2 \\
\hline $4 / 14 / 2012$ 20:25:01 & 42.8228 & -111.6423 & 1.1 ML IE & 130.6 & 7.21 & 6 & 222 & 22.1 & 0.04 & 2.3 & 3.0 \\
\hline $4 / 14 / 2012$ 20:25:42 & 42.8953 & -111.5668 & $0.7 \mathrm{ML}$ IE & 129.6 & 6.29 & 5 & 158 & 12.8 & 0.02 & 1.0 & 3.5 \\
\hline 4/14/2012 20:27:26 & 42.8730 & -111.6658 & $1.3 \mathrm{Mc} \mathrm{IE}$ & 125.3 & 2.34 & 12 & 166 & 21.2 & 0.07 & 0.6 & 11.8 \\
\hline 4/14/2012 20:29:20 & 42.9032 & -111.6048 & $0.9 \mathrm{ML} \mathrm{IE}$ & 126.7 & 2.69 & 11 & 118 & 15.5 & 0.09 & 0.6 & 10.4 \\
\hline 4/14/2012 20:31:23 & 42.8725 & -111.6740 & 1.7 ML IE & 124.8 & 5.37 & 15 & 167 & 21.9 & 0.06 & 0.6 & 3.1 \\
\hline $4 / 14 / 2012$ 20:46:21 & 42.8663 & -111.6725 & $1.6 \mathrm{Mc} \mathrm{IE}$ & 125.4 & 2.54 & 13 & 111 & 22.0 & 0.04 & 0.5 & 10.4 \\
\hline 4/14/2012 22:08:28 & 42.8850 & -111.6668 & 1.1 Mc IE & 124.3 & 2.02 & 9 & 164 & 20.9 & 0.08 & 0.8 & 14.2 \\
\hline 4/15/2012 1:19:53 & 42.8793 & -111.6852 & $0.9 \mathrm{Mc} \mathrm{IE}$ & 123.6 & 3.33 & 8 & 166 & 22.5 & 0.06 & 0.8 & 10.2 \\
\hline 4/15/2012 3:44:25 & 42.8643 & -111.6575 & $0.9 \mathrm{ML} \mathrm{IE}$ & 126.4 & 3.84 & 11 & 168 & 20.9 & 0.03 & 0.9 & 7.3 \\
\hline 4/17/2012 7:05:11 & 44.2650 & -114.2150 & $1.6 \mathrm{Mc} \mathrm{IE}$ & 133.7 & 1.45 & 9 & 227 & 71.6 & 0.07 & 1.6 & 2.4 \\
\hline 4/17/2012 9:07:44 & 43.3237 & -111.3057 & $1.3 \mathrm{Mc} \mathrm{IE}$ & 124.8 & 2.09 & 15 & 81 & 30.5 & 0.07 & 0.7 & 13.8 \\
\hline 4/17/2012 17:03:03 & 42.9728 & -111.4403 & $0.7 \mathrm{ML}$ IE & 132.4 & 7.76 & 7 & 226 & 4.2 & 0.08 & 2.0 & 1.9 \\
\hline 4/18/2012 3:16:44 & 43.4110 & -110.9007 & $0.6 \mathrm{ML}$ IE & 154.4 & 13.69 & 7 & 143 & 6.7 & 0.05 & 1.6 & 0.7 \\
\hline 4/18/2012 10:30:31 & 44.5760 & -112.9640 & $2.0 \mathrm{Mc} \mathrm{MB}$ & 104.0 & 9.30 & 25 & 169 & 29.4 & 0.09 & 0.4 & 2.6 \\
\hline 4/19/2012 11:28:42 & 43.1740 & -111.3947 & $0.7 \mathrm{Mc}$ IE & 124.2 & 3.39 & 10 & 197 & 13.5 & 0.04 & 1.1 & 6.8 \\
\hline 4/19/2012 21:13:27 & 42.5967 & -111.4290 & $0.8 \mathrm{ML}$ IE & 160.8 & 4.76 & 6 & 305 & 32.8 & 0.05 & 2.0 & 5.3 \\
\hline 4/20/2012 4:18:16 & 42.9288 & -111.5068 & $0.5 \mathrm{ML}$ IE & 131.0 & 7.05 & 6 & 280 & 7.0 & 0.02 & 1.7 & 1.2 \\
\hline $4 / 20 / 2012$ 7:53:52 & 44.6002 & -112.0920 & $1.5 \mathrm{Mc} \mathrm{MB}$ & 119.3 & 6.02 & 16 & 132 & 24.0 & 0.07 & 0.6 & 11.5 \\
\hline $4 / 21 / 20126: 21: 03$ & 44.7463 & -111.8810 & 1.6 Mc MB & 141.7 & 4.96 & 21 & 135 & 17.2 & 0.09 & 0.6 & 1.4 \\
\hline $4 / 21 / 20128: 10: 37$ & 44.6243 & -113.8952 & $0.8 \mathrm{Mc} \mathrm{IE}$ & 140.2 & 3.10 & 6 & 234 & 52.3 & 0.10 & 1.8 & 6.1 \\
\hline $4 / 22 / 20126: 21: 36$ & 43.5607 & -110.9657 & $0.2 \mathrm{Mc} \mathrm{IE}$ & 147.0 & 6.48 & 10 & 160 & 7.9 & 0.04 & 0.8 & 1.8 \\
\hline 4/22/2012 22:09:59 & 43.7877 & -110.9750 & $0.9 \mathrm{Mc} \mathrm{IE}$ & 146.4 & 3.55 & 9 & 145 & 12.5 & 0.03 & 0.7 & 6.5 \\
\hline
\end{tabular}




\begin{tabular}{|c|c|c|c|c|c|c|c|c|c|c|c|}
\hline ORIGIN TIME & LAT N & LONG W & MAG-TYPE & DIST & Z & NO & GAP & DMIN & RMS & $\mathrm{ERH}$ & $\mathrm{ERZ}$ \\
\hline 4/22/2012 22:13:13 & 43.7877 & -110.9748 & $2.4 \mathrm{Mc} \mathrm{IE}$ & 146.4 & 3.28 & 34 & 97 & 12.5 & 0.06 & 0.4 & 4.0 \\
\hline 4/22/2012 22:22:43 & 43.7882 & -110.9750 & $2.5 \mathrm{ML} \mathrm{IE}$ & 146.4 & 2.49 & 39 & 97 & 12.4 & 0.05 & 0.4 & 7.4 \\
\hline 4/22/2012 22:30:34 & 43.7880 & -110.9728 & $2.0 \mathrm{ML} \mathrm{IE}$ & 146.6 & 1.94 & 36 & 98 & 12.4 & 0.06 & 0.5 & 1.7 \\
\hline 4/22/2012 22:33:17 & 43.7893 & -110.9810 & $0.9 \mathrm{Mc} \mathrm{IE}$ & 146.0 & 1.17 & 8 & 148 & 12.4 & 0.04 & 1.0 & 2.8 \\
\hline 4/22/2012 23:36:30 & 43.7917 & -110.9957 & $0.3 \mathrm{Mc}$ IE & 144.8 & 2.19 & 6 & 192 & 12.6 & 0.03 & 3.3 & 12.7 \\
\hline 4/22/2012 23:48:59 & 43.7890 & -110.9740 & 1.0 ML IE & 146.5 & 3.82 & 10 & 145 & 12.3 & 0.07 & 0.7 & 5.1 \\
\hline $4 / 23 / 2012$ 2:02:26 & 43.7838 & -110.9758 & $0.3 \mathrm{Mc} \mathrm{IE}$ & 146.3 & 2.50 & 9 & 145 & 12.9 & 0.06 & 0.8 & 11.3 \\
\hline 4/23/2012 3:47:59 & 43.7885 & -110.9790 & $0.3 \mathrm{Mc} \mathrm{IE}$ & 146.1 & 2.07 & 9 & 146 & 12.5 & 0.03 & 0.7 & 12.8 \\
\hline 4/23/2012 18:16:35 & 44.1270 & -114.3112 & 1.3 Mc IE & 133.7 & 4.13 & 11 & 246 & 63.2 & 0.03 & 1.9 & 5.1 \\
\hline 4/25/2012 5:58:29 & 44.6205 & -112.6285 & $1.5 \mathrm{Mc} \mathrm{MB}$ & 108.7 & 5.50 & 16 & 102 & 18.8 & 0.06 & 0.6 & 1.0 \\
\hline 4/25/2012 6:59:20 & 43.5165 & -111.2395 & $0.6 \mathrm{ML} \mathrm{IE}$ & 125.5 & 6.03 & 8 & 271 & 21.9 & 0.07 & 1.8 & 5.8 \\
\hline 4/25/2012 8:01:05 & 43.3417 & -110.9402 & 1.5 ML IE & 152.9 & 6.42 & 11 & 121 & 7.5 & 0.03 & 0.5 & 1.4 \\
\hline $4 / 25 / 20128: 01: 43$ & 43.3335 & -110.9450 & $0.9 \mathrm{ML} \mathrm{IE}$ & 152.7 & 6.90 & 9 & 157 & 8.2 & 0.05 & 0.7 & 1.5 \\
\hline 4/25/2012 14:47:59 & 44.3602 & -114.0135 & $1.3 \mathrm{Mc} \mathrm{IE}$ & 126.4 & 0.15 & 13 & 259 & 65.7 & 0.08 & 1.7 & 3.4 \\
\hline $4 / 25 / 2012$ 17:34:31 & 44.3332 & -113.9465 & $2.2 \mathrm{Mc} M B$ & 120.3 & 0.19 & 14 & 273 & 43.3 & 0.05 & 1.5 & 2.0 \\
\hline $4 / 26 / 20128: 10: 44$ & 43.3258 & -111.2923 & $0.6 \mathrm{ML} \mathrm{IE}$ & 125.8 & 4.99 & 7 & 199 & 30.9 & 0.08 & 1.0 & 11.4 \\
\hline 4/26/2012 21:32:55 & 43.3358 & -110.9235 & $0.4 \mathrm{ML} \mathrm{IE}$ & 154.3 & 9.07 & 6 & 284 & 6.5 & 0.07 & 1.6 & 2.6 \\
\hline 4/26/2012 22:30:41 & 42.5333 & -111.5978 & 1.5 ML IE & 157.3 & 3.54 & 11 & 97 & 48.3 & 0.06 & 0.4 & 11.7 \\
\hline $4 / 26 / 2012$ 22:35:12 & 42.5222 & -111.6235 & $2.0 \mathrm{Mc} \mathrm{IE}$ & 157.0 & 3.54 & 16 & 95 & 46.9 & 0.06 & 0.6 & 11.6 \\
\hline $4 / 27 / 2012$ 6:50:15 & 44.6152 & -112.1832 & 1.2 Mc MB & 117.6 & 5.20 & 7 & 141 & 32.3 & 0.13 & 1.0 & 4.9 \\
\hline $4 / 28 / 20128: 32: 21$ & 43.6460 & -110.8120 & $0.1 \mathrm{ML}$ IE & 158.9 & 2.50 & 7 & 122 & 17.2 & 0.10 & 0.7 & 14.1 \\
\hline $4 / 28 / 2012$ 17:43:07 & 43.6477 & -110.8120 & $0.4 \mathrm{ML} \mathrm{IE}$ & 158.9 & 3.09 & 7 & 123 & 17.3 & 0.04 & 0.7 & 11.2 \\
\hline $4 / 28 / 2012$ 17:46:49 & 43.6407 & -110.8127 & $0.2 \mathrm{Mc} \mathrm{IE}$ & 158.9 & 2.49 & 5 & 170 & 17.2 & 0.02 & 1.1 & 12.4 \\
\hline 4/28/2012 20:31:20 & 42.8572 & -111.2100 & 1.1 ML IE & 155.2 & 4.89 & 8 & 160 & 13.6 & 0.06 & 1.7 & 11.8 \\
\hline 4/29/2012 4:05:30 & 44.5868 & -113.8578 & 1.9 Mc MB & 135.1 & 3.61 & 13 & 292 & 80.0 & 0.13 & 1.7 & 3.1 \\
\hline 4/29/2012 4:07:17 & 44.5975 & -113.8687 & $1.8 \mathrm{Mc} \mathrm{MB}$ & 136.6 & 1.31 & 13 & 292 & 81.4 & 0.14 & 1.9 & 3.3 \\
\hline $4 / 29 / 20124: 35: 44$ & 44.5872 & -113.8650 & $1.3 \mathrm{Mc} \mathrm{IE}$ & 135.5 & 0.04 & 9 & 309 & 80.3 & 0.08 & 3.0 & 4.6 \\
\hline $4 / 30 / 2012$ 2:31:37 & 44.3683 & -112.6805 & 1.3 Mc IE & 80.3 & 3.68 & 15 & 223 & 29.1 & 0.08 & 0.7 & 1.1 \\
\hline 4/30/2012 5:47:41 & 44.3462 & -112.6522 & $0.8 \mathrm{ML} \mathrm{IE}$ & 78.2 & 3.69 & 14 & 216 & 26.7 & 0.04 & 0.9 & 1.1 \\
\hline 4/30/2012 19:03:58 & 43.9320 & -114.0485 & 1.4 ML IE & 106.5 & 8.31 & 10 & 234 & 47.9 & 0.03 & 1.1 & 12.5 \\
\hline 5/1/2012 5:29:29 & 43.6127 & -110.8353 & $0.5 \mathrm{ML} \mathrm{IE}$ & 157.2 & 7.13 & 9 & 104 & 15.7 & 0.06 & 0.4 & 2.9 \\
\hline 5/2/2012 11:11:22 & 44.6095 & -112.1647 & $1.2 \mathrm{Mc} M B$ & 117.7 & 15.22 & 8 & 245 & 32.2 & 0.07 & 1.4 & 0.7 \\
\hline $5 / 2 / 2012$ 14:14:57 & 43.5082 & -111.0713 & 1.0 ML IE & 139.1 & 10.32 & 11 & 222 & 10.0 & 0.10 & 1.0 & 1.2 \\
\hline 5/2/2012 14:32:38 & 42.7047 & -111.4272 & $0.9 \mathrm{ML} \mathrm{IE}$ & 152.3 & 2.56 & 11 & 143 & 25.9 & 0.07 & 0.9 & 12.7 \\
\hline $5 / 2 / 2012$ 15:21:50 & 42.6985 & -111.7648 & 1.1 ML IE & 134.4 & 7.77 & 10 & 97 & 38.7 & 0.07 & 0.5 & 4.2 \\
\hline 5/3/2012 3:25:19 & 42.6813 & -111.7042 & $0.6 \mathrm{Mc} \mathrm{IE}$ & 138.9 & 5.00 & 8 & 213 & 49.5 & 0.05 & 1.3 & 12.9 \\
\hline $5 / 3 / 20126: 36: 44$ & 42.7082 & -111.4158 & 1.1 Mc IE & 152.7 & 5.97 & 12 & 129 & 25.5 & 0.04 & 0.4 & 4.3 \\
\hline 5/4/2012 2:45:32 & 43.0577 & -111.1667 & $0.5 \mathrm{ML} \mathrm{IE}$ & 146.6 & 5.07 & 6 & 134 & 16.6 & 0.06 & 0.8 & 9.6 \\
\hline 5/4/2012 2:47:24 & 43.0648 & -111.1905 & $0.8 \mathrm{ML}$ IE & 144.5 & 16.15 & 8 & 128 & 14.7 & 0.03 & 0.5 & 1.0 \\
\hline 5/6/2012 9:12:51 & 42.8477 & -111.2633 & $0.6 \mathrm{Mc} \mathrm{IE}$ & 152.3 & 10.45 & 7 & 184 & 16.2 & 0.03 & 1.8 & 4.4 \\
\hline 5/6/2012 9:40:38 & 42.8522 & -111.2612 & $0.5 \mathrm{ML} \mathrm{IE}$ & 152.1 & 4.83 & 6 & 181 & 16.2 & 0.02 & 1.9 & 11.9 \\
\hline $5 / 6 / 2012$ 20:20:00 & 43.3487 & -111.1533 & 1.0 ML IE & 135.9 & 6.66 & 10 & 166 & 22.7 & 0.07 & 0.6 & 7.1 \\
\hline 5/8/2012 14:25:17 & 43.1415 & -110.9467 & $0.6 \mathrm{ML} \mathrm{IE}$ & 159.1 & 7.98 & 10 & 170 & 25.7 & 0.04 & 0.9 & 4.5 \\
\hline 5/8/2012 19:35:18 & 44.6030 & -112.1062 & $0.9 \mathrm{Mc} M B$ & 119.0 & 4.01 & 8 & 133 & 22.9 & 0.08 & 1.0 & 1.8 \\
\hline 5/9/2012 15:44:46 & 44.6262 & -112.1242 & 1.3 Mc MB & 120.7 & 5.37 & 11 & 140 & 21.8 & 0.01 & 0.5 & 12.4 \\
\hline $5 / 9 / 2012$ 21:27:42 & 42.7383 & -111.7253 & $1.5 \mathrm{ML} \mathrm{IE}$ & 132.9 & 8.02 & 8 & 132 & 45.5 & 0.02 & 0.8 & 11.5 \\
\hline $5 / 10 / 2012$ 6:45:23 & 43.4120 & -110.8865 & 1.0 ML IE & 155.5 & 0.92 & 10 & 136 & 6.2 & 0.07 & 0.9 & 2.0 \\
\hline 5/11/2012 10:38:10 & 42.8862 & -111.2088 & $0.9 \mathrm{ML} \mathrm{IE}$ & 153.4 & 10.26 & 12 & 143 & 16.1 & 0.06 & 0.7 & 2.5 \\
\hline 5/11/2012 16:40:55 & 44.5882 & -112.4540 & 1.4 Mc MB & 107.6 & 2.62 & 10 & 131 & 4.8 & 0.05 & 1.1 & 1.7 \\
\hline
\end{tabular}




\begin{tabular}{|c|c|c|c|c|c|c|c|c|c|c|c|}
\hline ORIGIN TIME & LAT N & LONG W & MAG-TYPE & DIST & Z & NO & GAP & DMIN & RMS & $\mathrm{ERH}$ & ERZ \\
\hline 5/11/2012 17:48:01 & 44.6327 & -112.3772 & $0.9 \mathrm{Mc} M B$ & 114.0 & 5.77 & 6 & 230 & 4.6 & 0.02 & 2.2 & 0.4 \\
\hline $5 / 12 / 20124: 35: 47$ & 44.3953 & -114.2013 & 1.1 Mc IE & 140.7 & 5.03 & 8 & 273 & 79.3 & 0.06 & 2.2 & 3.7 \\
\hline 5/12/2012 21:22:10 & 43.3770 & -110.8705 & $0.2 \mathrm{Mc} \mathrm{IE}$ & 157.5 & 7.88 & 7 & 196 & 2.2 & 0.04 & 1.5 & 2.3 \\
\hline 5/13/2012 12:55:39 & 43.8755 & -111.0250 & $0.3 \mathrm{Mc} \mathrm{IE}$ & 143.7 & 4.85 & 9 & 160 & 7.3 & 0.05 & 0.8 & 2.5 \\
\hline 5/14/2012 16:14:26 & 43.4320 & -110.8865 & 1.3 ML IE & 155.1 & 8.59 & 9 & 164 & 8.2 & 0.08 & 2.0 & 1.5 \\
\hline 5/15/2012 3:10:38 & 43.1573 & -111.2972 & $0.6 \mathrm{ML} \mathrm{IE}$ & 132.2 & 2.44 & 9 & 156 & 13.0 & 0.08 & 0.9 & 12.7 \\
\hline 5/16/2012 14:12:04 & 45.0203 & -112.7187 & $1.5 \mathrm{Mc} \mathrm{MB}$ & 152.5 & 5.90 & 8 & 264 & 23.7 & 0.01 & 7.1 & 6.4 \\
\hline 5/17/2012 10:38:21 & 42.8602 & -111.3158 & $0.6 \mathrm{ML} \mathrm{IE}$ & 148.0 & 2.18 & 7 & 196 & 12.2 & 0.05 & 0.8 & 12.9 \\
\hline 5/17/2012 10:41:32 & 42.8637 & -111.3108 & $0.5 \mathrm{ML}$ IE & 148.1 & 6.65 & 7 & 191 & 12.2 & 0.04 & 1.2 & 4.7 \\
\hline 5/18/2012 15:05:49 & 44.6120 & -112.5938 & $0.9 \mathrm{Mc} \mathrm{MB}$ & 108.1 & 6.33 & 6 & 137 & 16.0 & 0.06 & 0.9 & 10.9 \\
\hline 5/20/2012 22:15:35 & 43.6277 & -110.8950 & $0.7 \mathrm{ML} \mathrm{IE}$ & 152.3 & 5.51 & 9 & 100 & 10.7 & 0.02 & 0.4 & 3.0 \\
\hline 5/21/2012 12:36:49 & 44.6833 & -113.9542 & 1.0 Mc IE & 148.3 & 7.42 & 8 & 242 & 89.0 & 0.04 & 1.3 & 1.7 \\
\hline $5 / 22 / 2012$ 7:55:39 & 44.4552 & -114.2255 & 1.2 ML IE & 146.2 & 13.35 & 8 & 222 & 85.1 & 0.02 & 1.0 & 3.9 \\
\hline 5/22/2012 14:24:44 & 42.9365 & -111.2083 & 1.3 ML IE & 150.4 & 9.21 & 12 & 123 & 17.4 & 0.04 & 0.5 & 2.8 \\
\hline 5/23/2012 10:09:07 & 42.6447 & -111.4350 & 1.2 ML IE & 156.6 & 2.77 & 14 & 104 & 30.5 & 0.06 & 0.5 & 10.2 \\
\hline 5/24/2012 21:47:29 & 44.6473 & -112.9292 & 1.3 Mc IE & 111.6 & 5.14 & 8 & 169 & 21.0 & 0.02 & 1.6 & 4.1 \\
\hline 5/27/2012 13:39:44 & 44.6572 & -112.3325 & 1.7 Mc MB & 117.7 & 4.11 & 12 & 145 & 8.6 & 0.03 & 0.9 & 0.6 \\
\hline 5/28/2012 16:35:55 & 44.3110 & -112.6955 & $0.9 \mathrm{Mc} \mathrm{MB}$ & 73.9 & 2.11 & 11 & 139 & 24.3 & 0.05 & 0.6 & 1.0 \\
\hline 5/28/2012 20:58:31 & 43.1695 & -110.9870 & $0.5 \mathrm{ML}$ IE & 154.9 & 10.97 & 9 & 165 & 24.1 & 0.02 & 0.8 & 3.5 \\
\hline $5 / 29 / 20128: 30: 47$ & 44.0548 & -114.4537 & $1.8 \mathrm{Mc} \mathrm{MB}$ & 141.6 & 3.41 & 16 & 254 & 54.8 & 0.06 & 0.9 & 2.9 \\
\hline 5/29/2012 14:23:27 & 44.2572 & -114.0808 & 1.7 Mc MB & 124.1 & 6.87 & 14 & 217 & 54.3 & 0.05 & 0.6 & 2.5 \\
\hline 5/29/2012 14:28:32 & 44.2542 & -114.0288 & 1.4 ML IE & 120.5 & 4.91 & 6 & 288 & 50.2 & 0.06 & 4.9 & 10.1 \\
\hline 5/30/2012 11:04:22 & 44.3095 & -112.7058 & $0.6 \mathrm{Mc} \mathrm{IE}$ & 73.6 & 2.33 & 6 & 136 & 24.2 & 0.03 & 0.9 & 2.4 \\
\hline 5/31/2012 21:40:01 & 43.4268 & -110.8843 & $0.4 \mathrm{ML} \mathrm{IE}$ & 155.4 & 8.44 & 7 & 164 & 7.6 & 0.03 & 0.8 & 2.3 \\
\hline 6/1/2012 17:59:53 & 43.4105 & -111.1138 & 1.9 ML IE & 137.5 & 9.87 & 16 & 93 & 15.9 & 0.06 & 0.4 & 1.5 \\
\hline 6/2/2012 11:26:14 & 44.7030 & -112.4787 & $1.5 \mathrm{Mc} \mathrm{MB}$ & 119.7 & 6.06 & 21 & 125 & 13.9 & 0.03 & 0.5 & 6.2 \\
\hline 6/3/2012 7:09:59 & 42.8647 & -111.3072 & $0.5 \mathrm{ML}$ IE & 148.3 & 9.08 & 6 & 189 & 12.4 & 0.12 & 2.8 & 6.6 \\
\hline 6/4/2012 3:00:16 & 43.4725 & -110.8715 & $0.4 \mathrm{ML} \mathrm{IE}$ & 155.6 & 14.41 & 7 & 118 & 6.7 & 0.04 & 0.9 & 3.0 \\
\hline 6/6/2012 3:14:34 & 43.7607 & -114.7417 & $1.7 \mathrm{Mc} \mathrm{MB}$ & 158.3 & 3.40 & 13 & 172 & 34.9 & 0.04 & 1.0 & 1.9 \\
\hline 6/6/2012 8:02:57 & 43.7485 & -114.7400 & 1.6 ML IE & 158.1 & 2.79 & 8 & 190 & 33.9 & 0.03 & 1.5 & 2.2 \\
\hline 6/6/2012 8:06:30 & 43.7710 & -114.7315 & $2.1 \mathrm{ML} \mathrm{IE}$ & 157.5 & 7.05 & 9 & 192 & 35.0 & 0.02 & 1.0 & 9.7 \\
\hline 6/7/2012 2:32:57 & 44.6850 & -114.0880 & $2.2 \mathrm{Mc} M B$ & 155.4 & 0.02 & 16 & 128 & 98.2 & 0.13 & 0.9 & 2.3 \\
\hline 6/8/2012 6:35:03 & 43.1777 & -110.9275 & $0.4 \mathrm{ML} \mathrm{IE}$ & 159.1 & 3.30 & 6 & 222 & 21.4 & 0.02 & 2.2 & 11.0 \\
\hline 6/8/2012 13:05:14 & 43.4152 & -110.8813 & $0.7 \mathrm{ML} \mathrm{IE}$ & 155.9 & 8.18 & 8 & 161 & 6.3 & 0.05 & 1.2 & 1.6 \\
\hline 6/8/2012 14:13:57 & 44.6488 & -114.0227 & $0.6 \mathrm{ML} \mathrm{IE}$ & 148.9 & 0.16 & 8 & 242 & 61.8 & 0.13 & 1.9 & 9.1 \\
\hline 6/10/2012 5:08:44 & 44.2412 & -114.0257 & $2.0 \mathrm{Mc} \mathrm{MB}$ & 119.5 & 4.15 & 14 & 211 & 50.1 & 0.09 & 0.8 & 3.0 \\
\hline 6/11/2012 22:53:10 & 43.1727 & -110.9135 & 1.0 ML IE & 160.4 & 5.08 & 11 & 172 & 21.7 & 0.03 & 1.0 & 5.5 \\
\hline 6/12/2012 19:52:35 & 43.9315 & -113.6917 & $0.3 \mathrm{ML} \mathrm{IE}$ & 79.5 & 1.84 & 8 & 153 & 19.3 & 0.02 & 0.9 & 2.6 \\
\hline 6/13/2012 6:58:55 & 44.6832 & -113.6687 & 1.3 Mc MB & 135.0 & 0.04 & 8 & 229 & 46.4 & 0.05 & 2.0 & 1.8 \\
\hline 6/14/2012 13:29:26 & 44.7615 & -113.0945 & 1.0 Mc MB & 126.1 & 5.23 & 6 & 222 & 20.8 & 0.06 & 5.5 & 12.2 \\
\hline 6/14/2012 14:30:08 & 44.7285 & -111.7922 & 1.3 Mc MB & 143.8 & 3.48 & 11 & 130 & 10.0 & 0.02 & 0.6 & 1.2 \\
\hline 6/15/2012 10:39:59 & 44.2788 & -114.1105 & $1.0 \mathrm{Mc} \mathrm{IE}$ & 127.4 & 6.38 & 10 & 249 & 56.4 & 0.05 & 1.0 & 3.4 \\
\hline 6/15/2012 21:35:18 & 44.2887 & -114.1103 & $0.6 \mathrm{ML} \mathrm{IE}$ & 128.0 & 7.47 & 8 & 250 & 56.3 & 0.04 & 1.1 & 12.9 \\
\hline 6/16/2012 17:34:32 & 44.2557 & -113.8155 & 1.2 Mc IE & 106.8 & 1.67 & 9 & 298 & 33.3 & 0.05 & 1.8 & 2.2 \\
\hline 6/17/2012 17:08:36 & 44.6825 & -112.5442 & $0.5 \mathrm{ML} \mathrm{IE}$ & 116.4 & 3.47 & 6 & 185 & 15.5 & 0.01 & 5.1 & 7.1 \\
\hline 6/18/2012 21:19:45 & 43.2653 & -110.9220 & 1.4 ML IE & 156.5 & 4.29 & 11 & 162 & 12.2 & 0.06 & 0.8 & 3.5 \\
\hline 6/19/2012 13:57:37 & 43.1135 & -111.4077 & $1.5 \mathrm{Mc} \mathrm{IE}$ & 126.4 & 4.40 & 23 & 88 & 7.3 & 0.08 & 0.5 & 1.2 \\
\hline 6/21/2012 5:24:46 & 42.6407 & -111.6425 & 2.1 Mc IE & 145.6 & 3.81 & 20 & 120 & 37.6 & 0.06 & 0.4 & 6.8 \\
\hline 6/24/2012 9:10:58 & 44.6545 & -114.0207 & 1.8 Mc IE & 149.3 & 2.83 & 8 & 219 & 62.1 & 0.03 & 0.9 & 3.1 \\
\hline
\end{tabular}




\begin{tabular}{|c|c|c|c|c|c|c|c|c|c|c|c|}
\hline ORIGIN TIME & LAT N & LONG W & MAG-TYPE & DIST & Z & NO & GAP & DMIN & RMS & $\mathrm{ERH}$ & $\mathrm{ERZ}$ \\
\hline 6/25/2012 11:12:12 & 44.6465 & -114.0040 & $2.1 \mathrm{Mc} M B$ & 147.7 & 0.05 & 14 & 217 & 60.5 & 0.11 & 0.9 & 2.2 \\
\hline 6/25/2012 12:44:10 & 43.9297 & -114.3635 & $0.9 \mathrm{Mc} \mathrm{IE}$ & 130.9 & 7.56 & 8 & 235 & 40.9 & 0.03 & 1.2 & 12.6 \\
\hline 6/25/2012 16:27:11 & 43.2602 & -111.2725 & 1.2 ML IE & 129.7 & 3.20 & 11 & 163 & 24.3 & 0.09 & 0.8 & 11.9 \\
\hline 6/27/2012 6:48:35 & 42.8330 & -111.2662 & 1.8 ML IE & 153.0 & 2.54 & 16 & 156 & 15.5 & 0.06 & 0.4 & 11.6 \\
\hline 6/27/2012 6:49:56 & 42.8308 & -111.2647 & 1.4 ML IE & 153.3 & 7.95 & 8 & 195 & 15.3 & 0.07 & 1.1 & 5.2 \\
\hline $6 / 27 / 20126: 50: 32$ & 42.8237 & -111.2748 & 1.5 ML IE & 153.1 & 7.00 & 7 & 203 & 15.7 & 0.04 & 1.3 & 6.5 \\
\hline 6/27/2012 22:16:41 & 42.7438 & -111.3540 & 1.3 ML IE & 153.8 & 2.10 & 6 & 263 & 20.9 & 0.03 & 2.4 & 12.7 \\
\hline 7/1/2012 2:03:43 & 43.4208 & -110.8797 & $0.4 \mathrm{ML} \mathrm{IE}$ & 155.9 & 6.77 & 8 & 164 & 6.9 & 0.03 & 1.0 & 2.7 \\
\hline 7/1/2012 11:10:37 & 44.5287 & -113.8512 & 1.0 ML IE & 129.9 & 5.18 & 6 & 223 & 43.0 & 0.04 & 1.6 & 9.5 \\
\hline 7/1/2012 13:49:56 & 43.5783 & -111.1750 & $0.4 \mathrm{Mc} \mathrm{IE}$ & 130.0 & 2.75 & 7 & 256 & 13.7 & 0.07 & 1.3 & 9.8 \\
\hline 7/1/2012 23:11:37 & 43.2840 & -110.9160 & 1.0 ML IE & 156.4 & 2.31 & 7 & 161 & 10.1 & 0.01 & 1.1 & 11.3 \\
\hline 7/2/2012 9:25:40 & 44.6882 & -112.5253 & 1.2 Mc MB & 117.3 & 7.18 & 16 & 89 & 14.8 & 0.04 & 0.4 & 3.4 \\
\hline $7 / 2 / 2012$ 14:46:40 & 43.3432 & -111.0405 & $1.8 \mathrm{Mc} \mathrm{IE}$ & 144.9 & 8.90 & 22 & 134 & 15.4 & 0.09 & 0.5 & 1.6 \\
\hline 7/2/2012 18:09:27 & 43.4442 & -110.9733 & $0.8 \mathrm{ML} \mathrm{IE}$ & 148.0 & 3.62 & 9 & 217 & 5.4 & 0.05 & 1.0 & 1.5 \\
\hline $7 / 4 / 2012$ 12:17:26 & 43.4092 & -110.9448 & 1.1 ML IE & 150.9 & 8.99 & 10 & 222 & 9.0 & 0.05 & 1.2 & 0.9 \\
\hline $7 / 4 / 2012$ 18:04:28 & 44.5788 & -114.2345 & 1.1 Mc IE & 155.5 & 4.22 & 9 & 227 & 72.4 & 0.03 & 1.0 & 3.3 \\
\hline 7/5/2012 0:21:39 & 42.6423 & -111.4135 & 1.5 ML IE & 158.0 & 2.41 & 23 & 107 & 29.1 & 0.05 & 0.4 & 12.5 \\
\hline $7 / 5 / 20126: 43: 37$ & 43.7742 & -110.8618 & 1.5 ML IE & 155.4 & 6.67 & 22 & 110 & 15.0 & 0.05 & 0.4 & 2.2 \\
\hline 7/5/2012 9:30:11 & 44.3923 & -114.0647 & 1.2 Mc IE & 131.8 & 3.29 & 10 & 209 & 53.4 & 0.11 & 1.0 & 3.8 \\
\hline $7 / 5 / 2012$ 14:30:50 & 44.3802 & -112.7520 & 1.3 Mc IE & 81.3 & 2.83 & 14 & 90 & 32.5 & 0.02 & 0.5 & 1.3 \\
\hline $7 / 5 / 2012$ 22:15:34 & 43.0537 & -111.6708 & $0.9 \mathrm{ML} \mathrm{IE}$ & 111.9 & 9.64 & 8 & 268 & 24.0 & 0.07 & 1.9 & 3.0 \\
\hline $7 / 7 / 201220: 57: 13$ & 43.0053 & -111.3570 & $0.5 \mathrm{ML} \mathrm{IE}$ & 136.0 & 7.06 & 8 & 133 & 5.5 & 0.03 & 1.5 & 1.6 \\
\hline $7 / 7 / 2012$ 22:50:03 & 44.3875 & -113.0348 & $0.5 \mathrm{ML} \mathrm{IE}$ & 84.5 & 15.43 & 5 & 235 & 9.9 & 0.03 & 1.0 & 1.1 \\
\hline 7/8/2012 12:15:16 & 43.4547 & -110.8947 & $0.7 \mathrm{ML} \mathrm{IE}$ & 154.1 & 9.35 & 9 & 165 & 6.0 & 0.03 & 1.0 & 1.1 \\
\hline $7 / 9 / 2012$ 15:42:53 & 43.2290 & -111.3615 & $0.5 \mathrm{ML} \mathrm{IE}$ & 124.2 & 4.94 & 7 & 201 & 19.5 & 0.02 & 1.3 & 10.0 \\
\hline 7/10/2012 1:53:08 & 42.8185 & -111.2020 & $0.6 \mathrm{ML} \mathrm{IE}$ & 158.2 & 9.26 & 7 & 182 & 10.2 & 0.02 & 1.1 & 1.9 \\
\hline 7/10/2012 1:53:22 & 42.8107 & -111.1985 & 1.0 ML IE & 159.0 & 9.12 & 5 & 186 & 9.5 & 0.03 & 1.6 & 2.7 \\
\hline 7/10/2012 1:54:10 & 44.7320 & -112.4028 & 1.2 Mc MB & 124.2 & 10.86 & 8 & 244 & 15.4 & 0.02 & 1.9 & 2.1 \\
\hline 7/10/2012 2:58:07 & 42.8265 & -111.1978 & $0.3 \mathrm{ML}$ IE & 158.0 & 6.20 & 5 & 175 & 10.5 & 0.09 & 1.6 & 4.0 \\
\hline $7 / 10 / 2012$ 2:58:20 & 42.8237 & -111.1765 & $0.5 \mathrm{ML} \mathrm{IE}$ & 159.6 & 11.95 & 5 & 167 & 9.0 & 0.05 & 1.8 & 2.8 \\
\hline $7 / 10 / 2012$ 7:17:24 & 43.0180 & -111.4587 & $0.5 \mathrm{ML}$ IE & 128.3 & 7.27 & 7 & 222 & 8.2 & 0.04 & 1.5 & 1.4 \\
\hline 7/10/2012 20:51:44 & 42.7042 & -111.7975 & $0.9 \mathrm{Mc} \mathrm{IE}$ & 132.2 & 5.57 & 12 & 92 & 40.2 & 0.04 & 0.4 & 4.0 \\
\hline $7 / 11 / 2012$ 11:18:20 & 43.0200 & -111.4613 & $0.7 \mathrm{ML}$ IE & 128.0 & 5.79 & 11 & 125 & 8.3 & 0.02 & 0.9 & 1.1 \\
\hline 7/12/2012 6:39:39 & 44.3630 & -114.0060 & 1.7 Mc IE & 126.1 & 7.21 & 18 & 204 & 48.3 & 0.06 & 1.1 & 1.4 \\
\hline $7 / 12 / 2012$ 6:41:38 & 44.3390 & -113.9945 & 1.2 ML IE & 123.7 & 0.36 & 10 & 201 & 47.1 & 0.05 & 1.3 & 2.8 \\
\hline $7 / 12 / 2012$ 6:44:49 & 43.1458 & -111.3753 & $0.6 \mathrm{ML} \mathrm{IE}$ & 127.0 & 2.50 & 7 & 211 & 10.3 & 0.06 & 1.4 & 10.1 \\
\hline 7/12/2012 23:06:31 & 42.6775 & -111.6160 & $1.9 \mathrm{Mc} \mathrm{IE}$ & 143.9 & 4.50 & 13 & 172 & 33.0 & 0.02 & 0.7 & 9.5 \\
\hline 7/12/2012 23:44:48 & 44.4488 & -113.2992 & 1.3 Mc IE & 98.0 & 1.95 & 6 & 279 & 17.5 & 0.06 & 12.8 & 3.3 \\
\hline 7/13/2012 10:03:09 & 43.5090 & -110.9995 & $0.2 \mathrm{Mc} \mathrm{IE}$ & 144.8 & 3.31 & 8 & 209 & 4.5 & 0.04 & 1.5 & 2.9 \\
\hline 7/14/2012 11:43:22 & 43.5073 & -111.0097 & $0.6 \mathrm{ML} \mathrm{IE}$ & 144.0 & 1.33 & 10 & 214 & 5.1 & 0.04 & 1.0 & 0.7 \\
\hline 7/15/2012 6:43:18 & 44.1965 & -113.1488 & 1.1 Mc IE & 67.5 & 4.78 & 21 & 106 & 22.2 & 0.06 & 0.3 & 0.7 \\
\hline 7/15/2012 21:54:12 & 42.7662 & -111.6143 & 1.4 ML IE & 136.7 & 2.81 & 13 & 178 & 24.7 & 0.03 & 0.6 & 9.3 \\
\hline $7 / 16 / 2012$ 3:56:15 & 42.9638 & -111.2122 & $0.3 \mathrm{ML} \mathrm{IE}$ & 148.5 & 8.34 & 9 & 123 & 16.3 & 0.05 & 0.7 & 4.1 \\
\hline 7/16/2012 15:35:06 & 43.5062 & -111.0140 & $0.7 \mathrm{ML} \mathrm{IE}$ & 143.7 & 1.02 & 11 & 210 & 5.4 & 0.04 & 1.1 & 0.7 \\
\hline $7 / 17 / 20128: 34: 33$ & 43.7385 & -112.9085 & $0.3 \mathrm{ML} \mathrm{IE}$ & 14.1 & 9.61 & 12 & 94 & 2.6 & 0.07 & 0.8 & 0.8 \\
\hline 7/19/2012 8:35:20 & 43.3217 & -111.0423 & $0.4 \mathrm{Mc} \mathrm{IE}$ & 145.4 & 11.64 & 9 & 289 & 16.1 & 0.06 & 1.3 & 2.0 \\
\hline 7/20/2012 21:42:42 & 43.0827 & -111.3820 & $0.7 \mathrm{Mc} \mathrm{IE}$ & 129.9 & 2.71 & 8 & 189 & 3.4 & 0.09 & 1.1 & 1.5 \\
\hline 7/20/2012 23:20:37 & 43.7730 & -110.9970 & $0.5 \mathrm{ML} \mathrm{IE}$ & 144.5 & 4.88 & 10 & 153 & 14.5 & 0.02 & 0.8 & 3.4 \\
\hline 7/20/2012 23:54:53 & 43.7748 & -110.9962 & 2.1 ML IE & 144.6 & 5.38 & 29 & 85 & 14.3 & 0.04 & 0.4 & 1.7 \\
\hline
\end{tabular}




\begin{tabular}{|c|c|c|c|c|c|c|c|c|c|c|c|}
\hline ORIGIN TIME & LAT N & LONG W & MAG-TYPE & DIST & Z & NO & GAP & DMIN & RMS & $\mathrm{ERH}$ & $\mathrm{ERZ}$ \\
\hline 7/20/2012 23:57:42 & 43.7512 & -110.8750 & $0.5 \mathrm{ML}$ IE & 154.1 & 4.79 & 5 & 209 & 17.0 & 0.07 & 3.1 & 11.7 \\
\hline 7/20/2012 23:58:07 & 43.7720 & -110.9940 & 1.7 ML IE & 144.8 & 5.07 & 13 & 141 & 14.6 & 0.05 & 0.6 & 2.9 \\
\hline $7 / 21 / 2012$ 0:00:56 & 43.7750 & -111.0028 & $0.4 \mathrm{ML} \mathrm{IE}$ & 144.1 & 5.78 & 7 & 192 & 14.5 & 0.03 & 0.8 & 4.4 \\
\hline $7 / 21 / 2012$ 0:03:36 & 43.7728 & -110.9898 & $0.8 \mathrm{ML} \mathrm{IE}$ & 145.1 & 4.72 & 8 & 184 & 14.4 & 0.03 & 0.8 & 4.8 \\
\hline 7/21/2012 0:11:19 & 43.7752 & -111.0038 & $0.4 \mathrm{ML} \mathrm{IE}$ & 144.0 & 7.08 & 6 & 193 & 14.5 & 0.02 & 1.3 & 3.2 \\
\hline $7 / 21 / 2012$ 5:45:54 & 43.1075 & -111.4280 & $0.6 \mathrm{ML} \mathrm{IE}$ & 125.3 & 3.15 & 6 & 210 & 7.6 & 0.03 & 1.7 & 4.3 \\
\hline 7/21/2012 12:57:34 & 44.7683 & -111.8765 & 1.1 Mc MB & 144.0 & 4.97 & 4 & 144 & 17.2 & 0.09 & 3.9 & 9.9 \\
\hline 7/21/2012 13:16:17 & 43.3332 & -111.4157 & $0.8 \mathrm{ML} \mathrm{IE}$ & 116.0 & 4.97 & 8 & 210 & 31.3 & 0.07 & 1.5 & 11.8 \\
\hline 7/21/2012 13:17:01 & 43.2312 & -111.6472 & NM & 103.0 & 4.90 & 6 & 266 & 29.9 & 0.13 & 3.8 & 16.4 \\
\hline $7 / 21 / 2012$ 14:10:27 & 43.2205 & -111.6732 & $0.2 \mathrm{Mc} \mathrm{IE}$ & 101.7 & 4.94 & 6 & 272 & 30.8 & 0.03 & 3.8 & 12.5 \\
\hline 7/22/2012 13:22:35 & 43.4440 & -110.9262 & $0.3 \mathrm{Mc}$ IE & 151.7 & 6.79 & 9 & 193 & 5.5 & 0.06 & 0.8 & 1.4 \\
\hline $7 / 23 / 2012$ 14:51:28 & 42.7255 & -111.5658 & 1.5 ML IE & 142.7 & 2.51 & 11 & 188 & 26.4 & 0.06 & 0.7 & 12.1 \\
\hline $7 / 24 / 2012$ 14:12:50 & 44.7240 & -113.0290 & $2.3 \mathrm{Mc} \mathrm{MB}$ & 121.1 & 5.59 & 19 & 171 & 18.3 & 0.08 & 0.5 & 0.9 \\
\hline 7/24/2012 15:49:50 & 44.7182 & -113.0238 & 1.3 Mc MB & 120.4 & 4.33 & 10 & 171 & 18.4 & 0.05 & 0.7 & 2.0 \\
\hline 7/24/2012 19:50:55 & 44.3512 & -114.2942 & 1.0 ML IE & 144.1 & 7.08 & 5 & 267 & 71.0 & 0.10 & 1.3 & 14.8 \\
\hline 7/24/2012 22:12:24 & 44.1982 & -114.0688 & 1.4 ML IE & 119.9 & 4.91 & 16 & 211 & 54.5 & 0.04 & 0.7 & 3.1 \\
\hline 7/24/2012 22:33:14 & 44.2047 & -114.0700 & $2.3 \mathrm{Mc} \mathrm{MB}$ & 120.3 & 5.23 & 22 & 213 & 54.4 & 0.04 & 0.6 & 2.5 \\
\hline 7/25/2012 7:31:04 & 44.6347 & -112.7170 & 1.1 Mc IE & 109.7 & 10.00 & 8 & 129 & 23.9 & 0.09 & 0.9 & 2.6 \\
\hline 7/25/2012 15:56:03 & 43.4488 & -110.9172 & $0.4 \mathrm{ML}$ IE & 152.4 & 5.91 & 7 & 179 & 5.3 & 0.02 & 0.8 & 1.6 \\
\hline 7/28/2012 21:04:05 & 43.4302 & -113.5565 & 1.6 Mc IE & 67.1 & 20.46 & 20 & 155 & 4.6 & 0.10 & 0.5 & 0.4 \\
\hline 7/28/2012 22:20:24 & 44.7718 & -113.0892 & 1.2 Mc IE & 127.2 & 5.14 & 9 & 224 & 20.0 & 0.03 & 5.1 & 10.5 \\
\hline $7 / 29 / 2012$ 8:36:02 & 45.0872 & -112.7205 & 1.2 Mc MB & 160.0 & 5.11 & 9 & 164 & 30.6 & 0.03 & 1.2 & 1.9 \\
\hline 7/30/2012 4:32:08 & 42.8708 & -111.5960 & $1.0 \mathrm{Mc} \mathrm{IE}$ & 129.6 & 1.89 & 10 & 166 & 16.1 & 0.08 & 0.8 & 2.9 \\
\hline 7/30/2012 13:49:40 & 43.4030 & -111.0962 & $0.9 \mathrm{ML} \mathrm{IE}$ & 139.0 & 8.46 & 9 & 270 & 15.2 & 0.04 & 1.3 & 2.9 \\
\hline 7/30/2012 13:52:09 & 43.3973 & -111.1047 & 1.2 ML IE & 138.5 & 7.14 & 12 & 163 & 16.2 & 0.06 & 0.7 & 3.2 \\
\hline 7/31/2012 0:57:07 & 44.0592 & -113.2678 & $0.9 \mathrm{ML} \mathrm{IE}$ & 59.9 & 5.91 & 12 & 99 & 20.2 & 0.05 & 0.5 & 1.2 \\
\hline 7/31/2012 13:59:57 & 43.5593 & -112.1245 & 1.4 Mc IE & 54.1 & 12.87 & 24 & 127 & 8.8 & 0.12 & 0.7 & 0.4 \\
\hline 8/1/2012 6:26:57 & 44.0598 & -114.4658 & 1.4 ML IE & 142.7 & 3.98 & 13 & 256 & 55.5 & 0.04 & 1.2 & 3.2 \\
\hline 8/1/2012 22:48:36 & 44.6710 & -114.0985 & 1.1 ML IE & 154.8 & 1.34 & 10 & 128 & 68.1 & 0.03 & 0.7 & 2.0 \\
\hline 8/2/2012 21:17:15 & 44.6022 & -112.1170 & 1.1 Mc MB & 118.6 & 3.00 & 8 & 152 & 22.0 & 0.05 & 0.7 & 0.6 \\
\hline 8/4/2012 0:20:08 & 44.7577 & -111.5732 & $1.3 \mathrm{Mc} \mathrm{MB}$ & 156.6 & 11.20 & 10 & 138 & 7.9 & 0.04 & 0.9 & 0.5 \\
\hline 8/4/2012 18:25:20 & 45.0125 & -112.1908 & $2.1 \mathrm{Mc} M B$ & 158.8 & 5.81 & 10 & 165 & 49.3 & 0.06 & 0.5 & 13.5 \\
\hline $8 / 4 / 2012$ 20:16:37 & 43.5552 & -112.1340 & $1.0 \mathrm{ML}$ IE & 53.4 & 11.56 & 20 & 81 & 9.3 & 0.11 & 0.5 & 0.8 \\
\hline 8/4/2012 20:17:10 & 43.5153 & -112.1453 & $0.5 \mathrm{ML} \mathrm{IE}$ & 53.6 & 12.18 & 7 & 155 & 9.1 & 0.07 & 1.4 & 1.4 \\
\hline $8 / 4 / 201220: 30: 11$ & 43.5428 & -112.1347 & $0.6 \mathrm{Mc} \mathrm{IE}$ & 53.7 & 12.37 & 12 & 171 & 8.7 & 0.11 & 0.9 & 1.2 \\
\hline $8 / 5 / 2012$ 13:34:26 & 42.9860 & -111.3882 & $0.4 \mathrm{ML} \mathrm{IE}$ & 135.1 & 6.04 & 9 & 162 & 6.0 & 0.05 & 1.3 & 2.5 \\
\hline $8 / 5 / 2012$ 22:03:13 & 44.1337 & -113.0965 & $0.5 \mathrm{ML}$ IE & 59.4 & 4.47 & 12 & 80 & 15.2 & 0.09 & 0.3 & 1.0 \\
\hline 8/6/2012 14:37:05 & 43.1490 & -111.2083 & $0.7 \mathrm{ML} \mathrm{IE}$ & 139.2 & 0.00 & 8 & 142 & 16.9 & 0.09 & 1.1 & 4.5 \\
\hline 8/7/2012 4:06:04 & 43.3337 & -111.3335 & $0.7 \mathrm{Mc} \mathrm{IE}$ & 122.4 & 4.99 & 7 & 200 & 31.3 & 0.06 & 0.9 & 9.7 \\
\hline 8/7/2012 7:25:06 & 43.2478 & -110.9392 & 1.3 Mc IE & 155.7 & 5.10 & 17 & 112 & 14.6 & 0.07 & 0.6 & 2.7 \\
\hline 8/7/2012 15:04:43 & 42.6650 & -111.6693 & 1.5 ML IE & 142.1 & 3.50 & 7 & 216 & 36.5 & 0.06 & 1.1 & 12.7 \\
\hline 8/8/2012 1:07:10 & 44.3770 & -114.0582 & 1.9 Mc IE & 130.3 & 6.16 & 18 & 108 & 52.6 & 0.15 & 0.9 & 2.8 \\
\hline 8/8/2012 10:13:19 & 44.3628 & -113.1753 & $0.8 \mathrm{Mc} M B$ & 85.3 & 5.84 & 8 & 133 & 19.0 & 0.03 & 0.7 & 0.9 \\
\hline 8/10/2012 21:41:44 & 44.5038 & -112.7540 & $1.3 \mathrm{Mc} \mathrm{IE}$ & 95.0 & 6.19 & 9 & 101 & 24.5 & 0.06 & 0.6 & 12.7 \\
\hline 8/11/2012 5:04:37 & 44.1258 & -113.9297 & $0.9 \mathrm{Mc} \mathrm{IE}$ & 106.2 & 1.20 & 10 & 195 & 44.1 & 0.06 & 0.6 & 1.7 \\
\hline 8/11/2012 5:15:14 & 43.4955 & -110.8480 & $0.0 \mathrm{Mc} \mathrm{IE}$ & 157.2 & 2.22 & 8 & 126 & 8.3 & 0.07 & 0.8 & 13.3 \\
\hline 8/12/2012 12:00:28 & 43.0335 & -111.1173 & 1.1 ML IE & 151.4 & 4.48 & 12 & 145 & 20.8 & 0.03 & 0.4 & 5.0 \\
\hline 8/12/2012 14:43:57 & 42.6800 & -111.4072 & $0.8 \mathrm{ML} \mathrm{IE}$ & 155.4 & 3.27 & 9 & 289 & 26.9 & 0.04 & 1.9 & 10.7 \\
\hline $8 / 12 / 2012$ 19:00:45 & 44.7798 & -112.7997 & 1.6 Mc MB & 125.7 & 13.59 & 10 & 101 & 6.6 & 0.06 & 0.7 & 0.8 \\
\hline
\end{tabular}




\begin{tabular}{|c|c|c|c|c|c|c|c|c|c|c|c|}
\hline ORIGIN TIME & LAT N & LONG W & MAG-TYPE & DIST & Z & NO & GAP & DMIN & RMS & $\mathrm{ERH}$ & ERZ \\
\hline 8/12/2012 19:14:38 & 43.2437 & -111.1098 & 1.1 Mc IE & 142.7 & 8.89 & 8 & 169 & 24.7 & 0.06 & 0.9 & 3.4 \\
\hline 8/12/2012 23:23:26 & 44.0723 & -114.4868 & $2.2 \mathrm{Mc} M B$ & 144.7 & 6.85 & 20 & 195 & 57.0 & 0.07 & 0.6 & 1.9 \\
\hline $8 / 13 / 20126: 00: 40$ & 43.2820 & -110.9285 & 1.2 ML IE & 155.5 & 17.03 & 9 & 160 & 10.9 & 0.04 & 1.6 & 1.7 \\
\hline 8/13/2012 20:18:09 & 42.8157 & -111.3735 & $0.8 \mathrm{ML} \mathrm{IE}$ & 147.3 & 2.97 & 7 & 219 & 14.2 & 0.07 & 1.8 & 8.9 \\
\hline 8/14/2012 8:24:47 & 43.7532 & -111.0053 & $0.5 \mathrm{Mc}$ IE & 143.7 & 5.39 & 8 & 156 & 12.9 & 0.03 & 0.8 & 3.0 \\
\hline 8/14/2012 9:41:06 & 43.2440 & -111.2850 & 1.5 ML IE & 129.3 & 5.18 & 20 & 118 & 22.3 & 0.04 & 0.5 & 4.1 \\
\hline $8 / 14 / 2012$ 20:32:20 & 44.4312 & -112.9865 & $0.5 \mathrm{ML} \mathrm{IE}$ & 88.4 & 6.81 & 6 & 133 & 11.9 & 0.07 & 1.0 & 0.9 \\
\hline 8/15/2012 5:22:37 & 44.4552 & -112.9628 & $0.8 \mathrm{ML} \mathrm{IE}$ & 90.7 & 9.38 & 10 & 138 & 14.1 & 0.06 & 0.6 & 1.5 \\
\hline 8/15/2012 14:09:27 & 44.4323 & -113.2155 & $0.8 \mathrm{ML} \mathrm{IE}$ & 93.7 & 3.81 & 10 & 164 & 20.3 & 0.05 & 0.4 & 0.8 \\
\hline 8/16/2012 0:31:00 & 43.0423 & -111.3630 & $0.4 \mathrm{ML} \mathrm{IE}$ & 133.5 & 2.10 & 6 & 131 & 1.4 & 0.06 & 1.1 & 2.1 \\
\hline 8/16/2012 4:26:16 & 43.8223 & -110.9990 & $0.7 \mathrm{ML} \mathrm{IE}$ & 144.9 & 2.12 & 9 & 154 & 9.6 & 0.07 & 1.0 & 13.4 \\
\hline 8/16/2012 11:24:33 & 42.8370 & -111.2865 & 1.1 ML IE & 151.5 & 2.08 & 12 & 199 & 15.7 & 0.07 & 0.6 & 13.7 \\
\hline 8/16/2012 23:13:04 & 43.7528 & -111.0018 & $0.5 \mathrm{ML} \mathrm{IE}$ & 144.0 & 2.97 & 8 & 154 & 12.9 & 0.02 & 0.7 & 9.9 \\
\hline 8/18/2012 1:44:31 & 44.6350 & -112.5920 & 1.8 Mc MB & 110.6 & 13.21 & 11 & 106 & 16.4 & 0.03 & 0.8 & 1.5 \\
\hline 8/18/2012 12:34:19 & 44.6295 & -112.1018 & 1.3 Mc MB & 121.8 & 4.17 & 9 & 140 & 23.6 & 0.06 & 0.6 & 1.1 \\
\hline 8/20/2012 3:50:55 & 44.6287 & -113.0837 & $0.8 \mathrm{ML} \mathrm{IE}$ & 111.5 & 7.71 & 8 & 182 & 28.9 & 0.06 & 0.7 & 10.6 \\
\hline 8/23/2012 11:21:59 & 44.8278 & -111.7093 & $1.5 \mathrm{Mc} \mathrm{MB}$ & 156.6 & 4.30 & 15 & 198 & 11.4 & 0.03 & 0.8 & 0.5 \\
\hline 8/24/2012 14:48:06 & 44.6658 & -112.1210 & 1.4 Mc MB & 124.8 & 15.84 & 19 & 103 & 23.1 & 0.02 & 0.3 & 0.4 \\
\hline 8/25/2012 14:54:59 & 44.4562 & -114.3973 & 1.8 ML IE & 157.4 & 0.06 & 11 & 265 & 80.7 & 0.08 & 1.6 & 2.7 \\
\hline 8/25/2012 16:24:35 & 44.2685 & -113.9980 & $0.7 \mathrm{Mc}$ IE & 119.3 & 3.42 & 5 & 241 & 47.5 & 0.06 & 1.1 & 3.3 \\
\hline 8/26/2012 2:08:02 & 42.8415 & -111.2185 & 1.6 ML IE & 155.6 & 5.79 & 14 & 101 & 12.9 & 0.05 & 0.6 & 3.3 \\
\hline $8 / 26 / 20126: 50: 28$ & 42.7360 & -111.4985 & $2.4 \mathrm{Mc} \mathrm{IE}$ & 145.7 & 4.89 & 20 & 118 & 23.3 & 0.04 & 0.4 & 5.2 \\
\hline 8/26/2012 13:54:50 & 43.2403 & -111.2612 & $0.3 \mathrm{ML} \mathrm{IE}$ & 131.3 & 8.43 & 8 & 175 & 22.6 & 0.05 & 1.1 & 5.8 \\
\hline 8/26/2012 21:18:20 & 44.8698 & -112.7273 & $1.5 \mathrm{Mc} \mathrm{MB}$ & 135.8 & 11.82 & 8 & 125 & 10.7 & 0.03 & 0.7 & 1.5 \\
\hline 8/27/2012 0:43:50 & 44.4032 & -114.3503 & $1.2 \mathrm{Mc} \mathrm{IE}$ & 151.0 & 0.83 & 6 & 289 & 89.1 & 0.03 & 3.7 & 4.1 \\
\hline 8/28/2012 11:19:00 & 44.6957 & -112.9943 & 1.0 Mc MB & 117.6 & 0.19 & 6 & 164 & 18.7 & 0.04 & 1.2 & 2.5 \\
\hline 8/29/2012 11:27:16 & 44.6993 & -112.9960 & $1.5 \mathrm{Mc} \mathrm{M}$ & 118.0 & 3.99 & 14 & 165 & 18.4 & 0.02 & 0.5 & 1.1 \\
\hline 8/31/2012 2:23:08 & 44.7162 & -113.0118 & $1.2 \mathrm{Mc} \mathrm{M}$ & 120.0 & 0.11 & 8 & 203 & 17.9 & 0.06 & 1.0 & 5.4 \\
\hline 9/1/2012 10:42:17 & 42.6685 & -111.4943 & $0.7 \mathrm{ML} \mathrm{IE}$ & 151.3 & 4.98 & 8 & 146 & 34.0 & 0.06 & 0.7 & 9.8 \\
\hline 9/1/2012 14:04:36 & 43.2118 & -111.4637 & $0.5 \mathrm{Mc} \mathrm{IE}$ & 117.4 & 4.93 & 7 & 232 & 19.2 & 0.07 & 1.4 & 11.1 \\
\hline 9/2/2012 21:38:41 & 43.3145 & -111.0323 & 1.4 ML IE & 146.4 & 10.99 & 9 & 136 & 15.6 & 0.02 & 1.0 & 2.8 \\
\hline 9/2/2012 23:56:08 & 44.6175 & -112.1183 & 1.3 Mc MB & 120.1 & 14.20 & 10 & 94 & 22.1 & 0.04 & 0.7 & 1.0 \\
\hline $9 / 3 / 2012$ 14:59:56 & 43.2463 & -111.1042 & $0.3 \mathrm{ML}$ IE & 143.1 & 5.77 & 6 & 169 & 24.2 & 0.08 & 1.1 & 6.9 \\
\hline 9/4/2012 2:58:32 & 43.1642 & -110.9750 & 1.1 ML IE & 156.0 & 2.28 & 12 & 163 & 24.2 & 0.07 & 0.7 & 13.8 \\
\hline 9/4/2012 3:19:11 & 43.1728 & -110.9695 & $0.3 \mathrm{ML} \mathrm{IE}$ & 156.1 & 6.79 & 9 & 204 & 23.1 & 0.01 & 1.1 & 5.0 \\
\hline 9/4/2012 3:38:09 & 43.1737 & -110.9632 & $0.7 \mathrm{ML} \mathrm{IE}$ & 156.6 & 3.97 & 7 & 206 & 22.8 & 0.06 & 1.6 & 10.0 \\
\hline 9/4/2012 6:50:17 & 43.2570 & -111.0735 & $0.1 \mathrm{Mc} \mathrm{IE}$ & 145.0 & 3.82 & 6 & 171 & 21.5 & 0.08 & 2.6 & 11.3 \\
\hline 9/4/2012 8:00:30 & 43.1622 & -110.9690 & 1.0 ML IE & 156.6 & 5.46 & 10 & 164 & 24.2 & 0.04 & 0.8 & 6.0 \\
\hline 9/6/2012 5:13:36 & 43.2025 & -110.9002 & 1.2 Mc IE & 160.3 & 0.11 & 15 & 95 & 18.2 & 0.06 & 0.7 & 1.2 \\
\hline 9/6/2012 5:43:39 & 44.2208 & -113.1792 & $0.3 \mathrm{Mc} \mathrm{IE}$ & 71.0 & 7.86 & 7 & 117 & 20.6 & 0.05 & 0.6 & 10.7 \\
\hline 9/6/2012 6:26:12 & 43.3603 & -110.9585 & $0.8 \mathrm{ML} \mathrm{IE}$ & 151.0 & 7.99 & 7 & 262 & 8.7 & 0.02 & 1.2 & 2.1 \\
\hline 9/6/2012 10:19:36 & 43.1990 & -110.8958 & $0.6 \mathrm{ML} \mathrm{IE}$ & 160.8 & 8.03 & 10 & 173 & 18.5 & 0.09 & 1.0 & 2.8 \\
\hline 9/6/2012 22:31:33 & 44.3020 & -112.9138 & $0.9 \mathrm{ML} \mathrm{IE}$ & 73.3 & 11.11 & 11 & 163 & 3.7 & 0.07 & 0.6 & 0.7 \\
\hline 9/7/2012 5:44:40 & 43.2042 & -110.9017 & $0.8 \mathrm{Mc}$ IE & 160.1 & 2.34 & 13 & 102 & 18.0 & 0.06 & 0.7 & 12.0 \\
\hline 9/8/2012 20:13:08 & 44.4253 & -114.0145 & 1.3 ML IE & 131.1 & 0.05 & 5 & 283 & 50.2 & 0.03 & 1.0 & 2.3 \\
\hline 9/9/2012 19:00:39 & 44.0268 & -114.4952 & $0.8 \mathrm{ML} \mathrm{IE}$ & 143.9 & 7.93 & 7 & 257 & 52.1 & 0.07 & 1.4 & 13.6 \\
\hline 9/10/2012 5:54:36 & 43.2212 & -111.0083 & $0.8 \mathrm{ML} \mathrm{IE}$ & 151.3 & 8.82 & 9 & 151 & 20.2 & 0.07 & 0.9 & 2.8 \\
\hline 9/10/2012 12:42:31 & 44.3617 & -114.0638 & 1.2 ML IE & 129.7 & 4.81 & 13 & 122 & 52.8 & 0.04 & 0.7 & 2.5 \\
\hline 9/10/2012 21:57:38 & 44.6363 & -112.5927 & 1.1 Mc MB & 110.8 & 5.32 & 10 & 149 & 16.5 & 0.04 & 0.9 & 2.0 \\
\hline
\end{tabular}




\begin{tabular}{|c|c|c|c|c|c|c|c|c|c|c|c|}
\hline ORIGIN TIME & LAT N & LONG W & MAG-TYPE & DIST & Z & NO & GAP & DMIN & RMS & $\mathrm{ERH}$ & $\mathrm{ERZ}$ \\
\hline 9/12/2012 11:45:46 & 43.5117 & -110.9888 & $0.0 \mathrm{Mc} \mathrm{IE}$ & 145.7 & 5.87 & 5 & 202 & 14.4 & 0.04 & 3.6 & 5.2 \\
\hline 9/12/2012 13:30:44 & 43.5472 & -111.0173 & $0.8 \mathrm{ML} \mathrm{IE}$ & 143.0 & 5.42 & 9 & 204 & 10.1 & 0.06 & 0.8 & 2.3 \\
\hline 9/12/2012 16:27:01 & 43.5558 & -111.0122 & $0.4 \mathrm{Mc} \mathrm{IE}$ & 143.3 & 6.29 & 8 & 205 & 9.2 & 0.09 & 0.8 & 2.0 \\
\hline 9/14/2012 11:29:51 & 44.4720 & -114.0165 & $2.4 \mathrm{Mc} M B$ & 134.6 & 1.75 & 13 & 176 & 51.9 & 0.07 & 0.8 & 2.9 \\
\hline 9/15/2012 2:05:25 & 42.5672 & -111.5780 & 1.2 ML IE & 155.3 & 5.00 & 8 & 97 & 44.9 & 0.02 & 0.5 & 10.8 \\
\hline 9/15/2012 2:15:24 & 44.6895 & -111.9378 & 1.3 Mc MB & 133.9 & 4.48 & 12 & 112 & 22.0 & 0.06 & 0.5 & 1.2 \\
\hline 9/15/2012 15:43:05 & 44.6142 & -112.0763 & $2.8 \mathrm{Mc} \mathrm{MB}$ & 121.3 & 15.95 & 11 & 111 & 25.3 & 0.10 & 0.6 & 0.9 \\
\hline 9/16/2012 2:22:12 & 44.4420 & -112.6203 & $0.6 \mathrm{Mc} \mathrm{IE}$ & 89.1 & 3.81 & 8 & 80 & 24.6 & 0.07 & 0.4 & 1.1 \\
\hline 9/16/2012 10:49:49 & 43.0110 & -111.4137 & $0.6 \mathrm{Mc} \mathrm{IE}$ & 131.8 & 4.99 & 6 & 173 & 37.4 & 0.03 & 0.8 & 12.7 \\
\hline $9 / 16 / 2012$ 13:05:20 & 44.7442 & -111.7752 & 1.3 Mc MB & 146.0 & 9.54 & 13 & 142 & 8.8 & 0.03 & 0.6 & 1.0 \\
\hline 9/17/2012 20:13:30 & 45.0630 & -112.7170 & $1.2 \mathrm{Mc} \mathrm{M}$ & 157.3 & 3.21 & 7 & 161 & 28.1 & 0.03 & 2.6 & 3.6 \\
\hline 9/18/2012 6:15:01 & 44.6208 & -112.1265 & $1.2 \mathrm{Mc} \mathrm{MB}$ & 120.1 & 12.02 & 12 & 95 & 21.5 & 0.07 & 0.5 & 1.6 \\
\hline 9/18/2012 9:12:35 & 44.7190 & -112.2443 & 1.3 Mc MB & 126.5 & 11.78 & 11 & 109 & 18.3 & 0.04 & 0.5 & 1.6 \\
\hline 9/18/2012 22:16:25 & 44.6240 & -112.0935 & 1.0 Mc MB & 121.6 & 5.82 & 9 & 132 & 24.1 & 0.03 & 0.5 & 12.7 \\
\hline 9/19/2012 8:09:04 & 44.3423 & -111.0875 & $0.3 \mathrm{Mc}$ IE & 156.2 & 10.52 & 7 & 236 & 18.5 & 0.02 & 1.7 & 4.2 \\
\hline 9/20/2012 12:30:09 & 44.2482 & -114.1245 & $0.9 \mathrm{Mc} \mathrm{IE}$ & 126.5 & 6.84 & 6 & 245 & 57.8 & 0.10 & 2.0 & 5.6 \\
\hline 9/21/2012 20:51:55 & 43.2242 & -111.3967 & $0.5 \mathrm{Mc} \mathrm{IE}$ & 121.8 & 5.93 & 7 & 237 & 19.1 & 0.07 & 1.4 & 5.6 \\
\hline 9/22/2012 2:29:20 & 43.4420 & -113.6087 & 1.7 Mc IE & 70.6 & 21.56 & 13 & 247 & 2.5 & 0.09 & 0.7 & 1.0 \\
\hline 9/22/2012 2:30:17 & 43.4103 & -113.6095 & 1.0 Mc IE & 71.9 & 24.01 & 8 & 164 & 5.9 & 0.18 & 1.6 & 1.0 \\
\hline 9/22/2012 3:37:41 & 42.7438 & -111.7285 & $0.9 \mathrm{Mc} \mathrm{IE}$ & 132.3 & 4.99 & 7 & 97 & 45.2 & 0.19 & 0.8 & 17.7 \\
\hline 9/22/2012 8:35:50 & 43.9820 & -113.9110 & $0.7 \mathrm{ML} \mathrm{IE}$ & 97.9 & 6.98 & 9 & 186 & 37.3 & 0.18 & 0.9 & 19.7 \\
\hline 9/24/2012 12:12:08 & 42.5145 & -111.5678 & $0.6 \mathrm{Mc} \mathrm{IE}$ & 160.4 & 2.77 & 7 & 123 & 67.7 & 0.07 & 0.7 & 4.2 \\
\hline 9/25/2012 9:39:44 & 43.3953 & -110.9138 & $0.4 \mathrm{ML} \mathrm{IE}$ & 153.7 & 9.52 & 8 & 216 & 6.2 & 0.06 & 0.9 & 1.7 \\
\hline 9/25/2012 15:39:04 & 42.6612 & -111.6855 & 1.1 ML IE & 141.6 & 2.93 & 10 & 138 & 37.6 & 0.02 & 0.6 & 11.8 \\
\hline 9/26/2012 1:02:42 & 42.9355 & -111.4918 & 1.0 ML IE & 131.5 & 7.59 & 10 & 262 & 5.7 & 0.01 & 1.2 & 0.8 \\
\hline 9/26/2012 5:21:39 & 42.8952 & -111.2875 & $0.5 \mathrm{ML} \mathrm{IE}$ & 147.6 & 5.10 & 6 & 161 & 11.9 & 0.03 & 1.4 & 7.7 \\
\hline 9/27/2012 23:55:29 & 43.2362 & -110.9192 & $0.7 \mathrm{ML} \mathrm{IE}$ & 157.7 & 6.14 & 7 & 211 & 15.1 & 0.04 & 1.5 & 3.4 \\
\hline 9/28/2012 0:54:49 & 42.6427 & -111.4702 & 1.0 ML IE & 154.8 & 5.01 & 8 & 115 & 33.0 & 0.07 & 0.6 & 11.7 \\
\hline 9/28/2012 18:41:29 & 44.2608 & -114.0490 & 1.1 ML IE & 122.2 & 7.06 & 7 & 242 & 51.7 & 0.04 & 1.1 & 5.7 \\
\hline 9/29/2012 18:07:32 & 44.6467 & -114.1560 & 1.2 Mc IE & 156.0 & 6.98 & 9 & 226 & 70.4 & 0.08 & 0.8 & 2.2 \\
\hline 9/30/2012 12:49:00 & 43.4230 & -111.0008 & $0.3 \mathrm{Mc} \mathrm{IE}$ & 146.2 & 3.74 & 6 & 236 & 8.5 & 0.06 & 2.2 & 6.4 \\
\hline 10/1/2012 4:41:15 & 43.3382 & -110.9583 & $0.2 \mathrm{Mc} \mathrm{IE}$ & 151.5 & 14.10 & 7 & 155 & 9.0 & 0.04 & 1.3 & 2.2 \\
\hline 10/3/2012 18:59:24 & 43.3067 & -111.1602 & $0.6 \mathrm{ML} \mathrm{IE}$ & 136.7 & 5.01 & 6 & 164 & 25.8 & 0.06 & 0.8 & 10.6 \\
\hline 10/4/2012 7:47:46 & 43.2187 & -110.9288 & $0.8 \mathrm{Mc}$ IE & 157.5 & 2.07 & 6 & 321 & 17.1 & 0.05 & 2.1 & 13.2 \\
\hline 10/5/2012 16:29:36 & 44.6575 & -111.8860 & 1.2 Mc MB & 133.1 & 5.94 & 11 & 100 & 19.2 & 0.04 & 0.6 & 10.0 \\
\hline 10/5/2012 19:40:24 & 44.2063 & -113.0222 & 1.2 ML IE & 64.8 & 4.58 & 22 & 80 & 15.1 & 0.08 & 0.3 & 0.8 \\
\hline 10/7/2012 16:12:39 & 44.6148 & -112.5640 & 1.2 Mc MB & 108.8 & 4.88 & 12 & 122 & 13.7 & 0.03 & 0.6 & 1.2 \\
\hline $10 / 8 / 20122: 34: 34$ & 43.5255 & -112.7085 & $0.5 \mathrm{ML} \mathrm{IE}$ & 15.1 & 2.40 & 10 & 205 & 12.5 & 0.10 & 0.6 & 0.4 \\
\hline 10/8/2012 3:37:10 & 43.3315 & -111.0425 & $0.5 \mathrm{ML} \mathrm{IE}$ & 145.1 & 13.36 & 9 & 144 & 15.8 & 0.07 & 0.9 & 2.2 \\
\hline 10/8/2012 10:32:35 & 42.5772 & -111.5867 & 1.0 ML IE & 154.0 & 5.00 & 9 & 136 & 42.3 & 0.10 & 0.6 & 13.3 \\
\hline 10/8/2012 10:38:20 & 42.5860 & -111.5993 & 1.3 ML IE & 152.6 & 2.50 & 12 & 93 & 41.7 & 0.06 & 0.5 & 13.4 \\
\hline 10/9/2012 10:22:35 & 43.7392 & -111.0442 & $0.8 \mathrm{Mc} \mathrm{IE}$ & 140.5 & 2.32 & 12 & 176 & 11.3 & 0.06 & 0.8 & 9.9 \\
\hline 10/9/2012 10:23:56 & 43.7378 & -111.0572 & $0.7 \mathrm{ML} \mathrm{IE}$ & 139.4 & 2.18 & 12 & 182 & 11.3 & 0.07 & 1.5 & 12.1 \\
\hline 10/9/2012 10:25:16 & 43.7390 & -111.0453 & $0.5 \mathrm{Mc}$ IE & 140.4 & 2.02 & 8 & 213 & 11.3 & 0.07 & 1.2 & 13.9 \\
\hline 10/9/2012 13:59:46 & 43.7368 & -111.0423 & $0.4 \mathrm{Mc} \mathrm{IE}$ & 140.6 & 2.45 & 9 & 175 & 11.0 & 0.05 & 0.9 & 9.5 \\
\hline 10/10/2012 9:56:12 & 42.7490 & -111.2393 & 1.5 ML IE & 160.5 & 10.02 & 17 & 133 & 11.5 & 0.03 & 0.5 & 0.7 \\
\hline 10/10/2012 14:07:43 & 44.7047 & -111.8668 & 1.0 Mc MB & 138.3 & 5.94 & 8 & 159 & 16.2 & 0.03 & 0.7 & 11.0 \\
\hline 10/11/2012 2:27:36 & 44.7443 & -111.8682 & $1.0 \mathrm{Mc} \mathrm{MB}$ & 142.0 & 11.75 & 6 & 206 & 16.1 & 0.07 & 1.8 & 2.7 \\
\hline 10/11/2012 5:48:31 & 44.6322 & -112.1168 & 1.1 Mc M & 121.6 & 5.70 & 14 & 96 & 22.4 & 0.02 & 0.4 & 3.4 \\
\hline
\end{tabular}




\begin{tabular}{|c|c|c|c|c|c|c|c|c|c|c|c|}
\hline ORIGIN TIME & LAT N & LONG W & MAG-TYPE & DIST & Z & NO & GAP & DMIN & RMS & $\mathrm{ERH}$ & $\mathrm{ERZ}$ \\
\hline 10/11/2012 8:48:30 & 43.2438 & -110.9325 & 1.0 ML IE & 156.4 & 2.01 & 14 & 111 & 14.7 & 0.07 & 0.7 & 13.7 \\
\hline 10/11/2012 11:12:51 & 43.8983 & -113.9578 & $0.2 \mathrm{Mc} \mathrm{IE}$ & 98.5 & 7.54 & 7 & 220 & 40.8 & 0.07 & 1.4 & 13.2 \\
\hline 10/11/2012 11:13:19 & 43.3098 & -110.8740 & $0.2 \mathrm{Mc} \mathrm{IE}$ & 158.9 & 0.03 & 7 & 310 & 6.1 & 0.06 & 1.3 & 0.9 \\
\hline 10/12/2012 5:52:56 & 44.6948 & -111.9252 & 1.1 Mc MB & 135.0 & 5.25 & 12 & 114 & 20.9 & 0.05 & 0.4 & 1.1 \\
\hline 10/12/2012 9:13:45 & 44.7233 & -113.6992 & $2.4 \mathrm{Mc} M B$ & 140.1 & 7.83 & 9 & 243 & 51.5 & 0.08 & 2.0 & 1.7 \\
\hline 10/13/2012 0:45:01 & 42.8530 & -111.3078 & $0.4 \mathrm{ML} \mathrm{IE}$ & 149.0 & 12.21 & 5 & 197 & 13.2 & 0.02 & 1.1 & 2.2 \\
\hline 10/13/2012 15:21:49 & 44.9905 & -112.2583 & $2.4 \mathrm{Mc} \mathrm{MB}$ & 154.9 & 6.48 & 13 & 153 & 45.4 & 0.03 & 0.5 & 12.1 \\
\hline 10/14/2012 11:36:55 & 43.3103 & -110.8795 & $0.5 \mathrm{ML} \mathrm{IE}$ & 158.5 & 5.23 & 10 & 309 & 6.2 & 0.07 & 1.1 & 1.1 \\
\hline 10/17/2012 14:31:48 & 43.5105 & -111.0145 & $0.6 \mathrm{ML} \mathrm{IE}$ & 143.6 & 1.06 & 9 & 215 & 5.6 & 0.06 & 0.7 & 0.8 \\
\hline 10/18/2012 4:43:48 & 43.3043 & -111.1325 & 1.4 ML IE & 138.9 & 7.03 & 12 & 181 & 23.7 & 0.04 & 0.8 & 5.0 \\
\hline 10/18/2012 10:45:53 & 43.0333 & -111.3183 & $0.6 \mathrm{ML}$ IE & 137.1 & 4.91 & 10 & 104 & 4.8 & 0.04 & 0.7 & 1.7 \\
\hline 10/18/2012 10:48:18 & 43.0432 & -111.3277 & $0.6 \mathrm{ML} \mathrm{IE}$ & 135.9 & 6.08 & 11 & 101 & 3.7 & 0.07 & 0.6 & 1.1 \\
\hline 10/19/2012 7:19:43 & 43.5177 & -111.0052 & $0.2 \mathrm{Mc} \mathrm{IE}$ & 144.3 & 0.31 & 7 & 209 & 5.4 & 0.07 & 2.0 & 0.9 \\
\hline 10/19/2012 20:29:03 & 43.3043 & -111.1048 & 1.0 ML IE & 141.1 & 7.79 & 9 & 285 & 21.5 & 0.02 & 1.1 & 4.6 \\
\hline 10/21/2012 11:15:42 & 43.3620 & -110.9817 & $0.2 \mathrm{ML} \mathrm{IE}$ & 149.1 & 8.39 & 7 & 265 & 10.5 & 0.03 & 1.6 & 2.9 \\
\hline 10/22/2012 5:59:43 & 44.7132 & -112.4600 & 1.4 Mc MB & 121.1 & 1.63 & 7 & 96 & 14.3 & 0.08 & 0.6 & 1.4 \\
\hline 10/22/2012 11:08:24 & 42.9608 & -111.2912 & 1.3 ML IE & 143.2 & 5.27 & 15 & 113 & 10.9 & 0.05 & 0.4 & 2.2 \\
\hline 10/22/2012 11:11:55 & 42.9618 & -111.2848 & 1.3 ML IE & 143.6 & 4.58 & 12 & 112 & 11.5 & 0.03 & 0.4 & 3.3 \\
\hline 10/22/2012 11:21:38 & 42.9632 & -111.3062 & $0.7 \mathrm{ML}$ IE & 142.1 & 7.99 & 9 & 112 & 9.8 & 0.08 & 0.8 & 2.6 \\
\hline 10/22/2012 11:28:32 & 42.9642 & -111.3000 & $0.5 \mathrm{Mc}$ IE & 142.4 & 8.71 & 7 & 111 & 10.3 & 0.08 & 1.1 & 3.8 \\
\hline 10/22/2012 11:33:22 & 42.9615 & -111.3038 & 1.0 ML IE & 142.3 & 9.10 & 8 & 113 & 10.0 & 0.05 & 1.0 & 3.2 \\
\hline 10/22/2012 14:38:42 & 44.2685 & -111.1295 & $0.4 \mathrm{ML} \mathrm{IE}$ & 149.4 & 2.91 & 6 & 225 & 9.7 & 0.03 & 1.2 & 6.7 \\
\hline 10/23/2012 3:27:20 & 42.9605 & -111.3105 & $0.5 \mathrm{ML} \mathrm{IE}$ & 141.9 & 10.58 & 9 & 114 & 9.4 & 0.07 & 0.8 & 2.3 \\
\hline 10/23/2012 3:40:22 & 42.8693 & -111.2760 & 1.0 ML IE & 150.0 & 3.25 & 9 & 175 & 14.1 & 0.05 & 0.9 & 11.5 \\
\hline 10/23/2012 11:48:01 & 42.9053 & -111.2083 & $0.7 \mathrm{ML} \mathrm{IE}$ & 152.3 & 12.15 & 8 & 132 & 17.8 & 0.04 & 0.7 & 2.6 \\
\hline 10/24/2012 1:31:34 & 44.5097 & -112.8735 & 1.3 Mc MB & 95.9 & 5.01 & 4 & 120 & 35.4 & 0.07 & 0.8 & 13.6 \\
\hline 10/25/2012 12:24:23 & 44.7718 & -113.7700 & 1.6 Mc MB & 147.6 & 0.60 & 7 & 243 & 58.9 & 0.05 & 2.9 & 3.5 \\
\hline 10/25/2012 18:43:52 & 44.3222 & -111.1100 & $0.3 \mathrm{ML} \mathrm{IE}$ & 153.6 & 4.02 & 5 & 237 & 15.8 & 0.02 & 2.2 & 9.9 \\
\hline 10/26/2012 0:19:34 & 44.6192 & -112.0772 & 1.3 Mc MB & 121.7 & 4.55 & 10 & 95 & 25.3 & 0.06 & 0.6 & 1.2 \\
\hline 10/26/2012 11:41:53 & 44.8280 & -113.8987 & 1.1 ML IE & 158.5 & 0.31 & 11 & 138 & 69.6 & 0.18 & 1.5 & 8.5 \\
\hline 10/27/2012 15:33:48 & 44.3902 & -112.8123 & 1.1 Mc IE & 82.4 & 9.18 & 12 & 164 & 12.3 & 0.04 & 0.7 & 1.3 \\
\hline 10/27/2012 22:38:00 & 42.9655 & -111.1888 & $0.4 \mathrm{ML}$ IE & 150.0 & 9.28 & 8 & 128 & 17.7 & 0.08 & 0.6 & 4.5 \\
\hline 10/28/2012 9:23:03 & 43.7268 & -111.0410 & $0.6 \mathrm{ML}$ IE & 140.6 & 2.27 & 9 & 175 & 9.9 & 0.07 & 0.8 & 11.9 \\
\hline 10/28/2012 13:03:48 & 43.7365 & -111.0375 & $0.4 \mathrm{Mc}$ IE & 141.0 & 2.03 & 8 & 208 & 11.0 & 0.10 & 0.9 & 14.9 \\
\hline 10/28/2012 14:02:01 & 44.8150 & -113.8477 & $2.2 \mathrm{Mc} M B$ & 155.0 & 0.88 & 11 & 136 & 66.1 & 0.07 & 1.5 & 2.8 \\
\hline 10/28/2012 14:24:31 & 44.8088 & -113.8638 & 1.7 Mc MB & 155.1 & 0.54 & 10 & 135 & 66.3 & 0.06 & 1.4 & 2.8 \\
\hline 10/29/2012 6:38:44 & 43.6760 & -111.0532 & $0.6 \mathrm{ML} \mathrm{IE}$ & 139.5 & 2.09 & 10 & 192 & 4.7 & 0.08 & 0.9 & 10.1 \\
\hline 10/29/2012 10:49:07 & 42.8652 & -111.1937 & $0.8 \mathrm{ML} \mathrm{IE}$ & 155.8 & 5.06 & 10 & 149 & 13.5 & 0.04 & 0.7 & 5.8 \\
\hline 10/29/2012 16:47:27 & 42.8608 & -111.1940 & $2.3 \mathrm{ML} \mathrm{IE}$ & 156.0 & 11.07 & 17 & 115 & 13.1 & 0.04 & 0.3 & 0.9 \\
\hline 10/30/2012 14:36:48 & 44.0180 & -114.4357 & 1.4 Mc IE & 139.0 & 7.25 & 9 & 251 & 50.7 & 0.03 & 1.0 & 12.7 \\
\hline 10/31/2012 14:23:46 & 42.9077 & -111.5457 & $0.8 \mathrm{ML}$ IE & 130.0 & 7.42 & 8 & 154 & 10.7 & 0.06 & 0.6 & 1.4 \\
\hline 10/31/2012 17:49:51 & 44.9877 & -112.2363 & 1.7 Mc MB & 155.1 & 8.37 & 9 & 156 & 45.6 & 0.03 & 0.5 & 10.8 \\
\hline $11 / 1 / 2012$ 2:50:24 & 43.5830 & -111.2005 & $0.8 \mathrm{Mc} \mathrm{IE}$ & 127.9 & 4.29 & 7 & 261 & 15.3 & 0.02 & 1.7 & 5.1 \\
\hline $11 / 3 / 20128: 57: 14$ & 44.3590 & -114.0352 & $2.0 \mathrm{Mc} \mathrm{MB}$ & 127.7 & 5.01 & 15 & 206 & 50.5 & 0.10 & 1.4 & 13.8 \\
\hline 11/4/2012 18:46:57 & 42.6212 & -111.4312 & 1.2 ML IE & 158.7 & 8.00 & 12 & 108 & 31.5 & 0.10 & 0.5 & 4.2 \\
\hline 11/5/2012 1:15:32 & 44.4508 & -112.7830 & 1.3 Mc MB & 89.1 & 8.96 & 11 & 105 & 18.5 & 0.04 & 0.5 & 2.6 \\
\hline 11/5/2012 1:16:23 & 44.4520 & -112.7835 & 1.4 Mc MB & 89.2 & 7.08 & 13 & 105 & 18.5 & 0.10 & 0.6 & 8.8 \\
\hline 11/5/2012 1:18:08 & 44.4470 & -112.7837 & $1.2 \mathrm{Mc} \mathrm{MB}$ & 88.7 & 11.19 & 6 & 105 & 18.1 & 0.05 & 0.7 & 3.1 \\
\hline 11/5/2012 1:38:34 & 44.4457 & -112.7833 & 1.8 Mc IE & 88.5 & 13.10 & 6 & 106 & 18.0 & 0.05 & 0.8 & 2.7 \\
\hline
\end{tabular}




\begin{tabular}{|c|c|c|c|c|c|c|c|c|c|c|c|}
\hline ORIGIN TIME & LAT N & LONG W & MAG-TYPE & DIST & $z$ & NO & GAP & DMIN & RMS & ERH & ERZ \\
\hline $11 / 5 / 20123: 44: 50$ & 44.4442 & -112.7905 & 1.2 Mc MB & 88.4 & 6.91 & 6 & 161 & 17.5 & 0.05 & 1.0 & 13.1 \\
\hline 11/5/2012 5:32:42 & 44.4452 & -112.7808 & 1.2 Mc MB & 88.5 & 12.41 & 6 & 106 & 18.1 & 0.05 & 0.7 & 2.8 \\
\hline $11 / 5 / 20126: 22: 45$ & 44.4442 & -112.7820 & 1.2 Mc MB & 88.4 & 12.69 & 6 & 106 & 18.0 & 0.03 & 0.7 & 2.7 \\
\hline 11/5/2012 7:44:19 & 44.4460 & -112.7813 & 1.4 Mc MB & 88.6 & 12.69 & 6 & 106 & 18.2 & 0.04 & 0.7 & 2.8 \\
\hline 11/5/2012 8:10:55 & 44.4327 & -112.7823 & $0.7 \mathrm{ML}$ IE & 87.1 & 10.99 & 6 & 108 & 17.1 & 0.05 & 0.7 & 2.9 \\
\hline 11/5/2012 8:49:01 & 44.4378 & -112.7782 & $1.2 \mathrm{Mc} \mathrm{MB}$ & 87.6 & 11.12 & 6 & 108 & 17.7 & 0.04 & 0.7 & 3.0 \\
\hline 11/5/2012 13:58:29 & 43.7387 & -111.0423 & $0.4 \mathrm{Mc} \mathrm{IE}$ & 140.6 & 2.26 & 7 & 212 & 11.2 & 0.06 & 0.9 & 12.0 \\
\hline 11/5/2012 14:03:06 & 43.7383 & -111.0495 & $0.6 \mathrm{Mc} \mathrm{IE}$ & 140.0 & 2.31 & 8 & 216 & 11.3 & 0.06 & 1.0 & 10.9 \\
\hline $11 / 5 / 201214: 18: 07$ & 43.7387 & -111.0455 & $0.6 \mathrm{Mc} \mathrm{IE}$ & 140.4 & 2.15 & 9 & 176 & 11.3 & 0.06 & 0.9 & 12.8 \\
\hline 11/5/2012 19:20:30 & 43.7392 & -111.0488 & $0.5 \mathrm{ML}$ IE & 140.1 & 2.15 & 9 & 178 & 11.4 & 0.06 & 0.8 & 12.8 \\
\hline 11/5/2012 21:50:45 & 43.1592 & -110.9155 & $0.7 \mathrm{Mc} \mathrm{IE}$ & 160.8 & 3.02 & 10 & 174 & 23.2 & 0.05 & 1.2 & 11.6 \\
\hline 11/5/2012 23:33:16 & 43.4288 & -111.1057 & $0.7 \mathrm{ML}$ IE & 137.7 & 10.33 & 6 & 266 & 14.3 & 0.03 & 2.0 & 2.7 \\
\hline 11/6/2012 0:18:57 & 43.1605 & -110.9187 & $0.9 \mathrm{ML} \mathrm{IE}$ & 160.5 & 3.55 & 11 & 173 & 23.1 & 0.03 & 0.8 & 9.3 \\
\hline 11/6/2012 4:12:04 & 43.7375 & -111.0373 & $0.8 \mathrm{Mc} \mathrm{IE}$ & 141.0 & 2.00 & 10 & 172 & 11.1 & 0.13 & 1.1 & 16.3 \\
\hline 11/6/2012 5:12:24 & 42.6602 & -111.6517 & $0.8 \mathrm{ML}$ IE & 143.5 & 5.00 & 8 & 116 & 46.7 & 0.02 & 0.6 & 10.9 \\
\hline 11/6/2012 9:06:10 & 43.7398 & -111.0485 & $0.2 \mathrm{ML}$ IE & 140.1 & 2.32 & 9 & 215 & 11.4 & 0.06 & 0.9 & 11.0 \\
\hline 11/6/2012 10:11:17 & 43.7348 & -111.0365 & $0.7 \mathrm{Mc} \mathrm{IE}$ & 141.1 & 2.17 & 8 & 172 & 10.8 & 0.06 & 1.0 & 12.9 \\
\hline 11/6/2012 10:16:25 & 43.7385 & -111.0492 & $0.4 \mathrm{Mc} \mathrm{IE}$ & 140.1 & 2.43 & 7 & 216 & 11.3 & 0.03 & 1.2 & 10.7 \\
\hline $11 / 6 / 2012$ 10:59:02 & 43.2507 & -110.9158 & $0.3 \mathrm{Mc} \mathrm{IE}$ & 157.5 & 4.18 & 7 & 317 & 13.5 & 0.04 & 2.0 & 5.0 \\
\hline 11/6/2012 18:58:37 & 43.7320 & -111.0385 & 1.2 ML IE & 140.9 & 2.32 & 11 & 174 & 10.5 & 0.07 & 0.7 & 10.0 \\
\hline 11/6/2012 21:18:25 & 42.7445 & -111.6212 & 1.1 Mc IE & 138.0 & 2.51 & 8 & 299 & 27.0 & 0.09 & 1.7 & 13.5 \\
\hline 11/6/2012 23:09:38 & 42.9117 & -111.4905 & $0.5 \mathrm{ML} \mathrm{IE}$ & 133.2 & 2.84 & 6 & 275 & 6.3 & 0.05 & 2.2 & 4.5 \\
\hline 11/7/2012 5:39:55 & 43.7365 & -111.0408 & $0.2 \mathrm{ML}$ IE & 140.7 & 2.48 & 8 & 174 & 11.0 & 0.08 & 0.8 & 11.1 \\
\hline 11/7/2012 7:02:14 & 43.7335 & -111.0365 & $0.6 \mathrm{ML}$ IE & 141.0 & 2.14 & 10 & 173 & 10.6 & 0.06 & 0.8 & 12.5 \\
\hline 11/7/2012 7:14:55 & 43.7322 & -111.0405 & $0.9 \mathrm{Mc} \mathrm{IE}$ & 140.7 & 2.11 & 9 & 175 & 10.5 & 0.09 & 0.9 & 14.4 \\
\hline 11/7/2012 8:08:00 & 43.7340 & -111.0472 & 1.0 ML IE & 140.2 & 2.19 & 10 & 177 & 10.8 & 0.09 & 1.0 & 13.1 \\
\hline 11/7/2012 9:32:23 & 43.7340 & -111.0547 & $0.8 \mathrm{ML}$ IE & 139.6 & 2.07 & 10 & 181 & 10.9 & 0.10 & 1.3 & 14.9 \\
\hline 11/7/2012 11:21:01 & 42.9082 & -111.4850 & $1.6 \mathrm{Mc} \mathrm{IE}$ & 133.8 & 2.09 & 14 & 172 & 6.1 & 0.06 & 0.9 & 11.4 \\
\hline 11/7/2012 13:00:28 & 43.7365 & -111.0443 & $0.9 \mathrm{ML} \mathrm{IE}$ & 140.4 & 2.22 & 10 & 176 & 11.0 & 0.07 & 1.0 & 12.1 \\
\hline 11/7/2012 13:46:20 & 43.7338 & -111.0407 & $0.8 \mathrm{ML} \mathrm{IE}$ & 140.7 & 2.21 & 10 & 174 & 10.7 & 0.10 & 0.9 & 13.6 \\
\hline 11/7/2012 20:31:26 & 44.5267 & -114.3087 & 1.5 ML IE & 156.3 & 3.15 & 8 & 137 & 75.8 & 0.09 & 0.9 & 3.4 \\
\hline 11/7/2012 21:15:26 & 43.7385 & -111.0538 & 1.0 ML IE & 139.7 & 2.35 & 8 & 219 & 11.4 & 0.05 & 1.0 & 10.9 \\
\hline $11 / 7 / 201222: 35: 04$ & 43.8588 & -113.4442 & $1.1 \mathrm{ML} \mathrm{IE}$ & 58.1 & 4.64 & 14 & 108 & 7.8 & 0.06 & 0.4 & 0.7 \\
\hline 11/8/2012 4:42:38 & 43.7313 & -111.0263 & $0.3 \mathrm{Mc} \mathrm{IE}$ & 141.9 & 2.02 & 9 & 166 & 10.3 & 0.08 & 0.7 & 14.0 \\
\hline 11/8/2012 10:19:10 & 44.6987 & -111.9280 & 1.6 Mc MB & 135.2 & 4.43 & 7 & 115 & 21.1 & 0.07 & 0.8 & 2.3 \\
\hline 11/8/2012 17:13:09 & 44.4177 & -114.0940 & $1.9 \mathrm{Mc} \mathrm{IE}$ & 135.4 & 0.41 & 12 & 266 & 56.2 & 0.04 & 2.0 & 10.7 \\
\hline 11/8/2012 23:36:14 & 42.7508 & -111.8270 & 1.3 ML IE & 126.6 & 15.06 & 10 & 89 & 46.4 & 0.01 & 0.4 & 0.7 \\
\hline 11/9/2012 5:29:43 & 43.7272 & -111.0863 & $0.2 \mathrm{Mc} \mathrm{IE}$ & 137.0 & 2.51 & 5 & 195 & 11.0 & 0.07 & 2.7 & 11.7 \\
\hline 11/9/2012 7:35:19 & 43.7357 & -111.0320 & $0.4 \mathrm{Mc} \mathrm{IE}$ & 141.4 & 2.00 & 9 & 170 & 10.8 & 0.07 & 0.7 & 13.8 \\
\hline 11/9/2012 9:58:07 & 43.7367 & -111.0430 & $0.6 \mathrm{ML}$ IE & 140.5 & 2.23 & 9 & 175 & 11.0 & 0.08 & 0.8 & 12.6 \\
\hline 11/9/2012 11:25:59 & 43.7333 & -111.0372 & $0.5 \mathrm{Mc} \mathrm{IE}$ & 141.0 & 2.15 & 8 & 173 & 10.6 & 0.05 & 0.8 & 12.8 \\
\hline 11/9/2012 17:32:13 & 43.7385 & -111.0317 & $1.3 \mathrm{ML} \mathrm{IE}$ & 141.5 & 2.43 & 11 & 170 & 11.1 & 0.10 & 0.7 & 10.6 \\
\hline 11/9/2012 17:38:40 & 43.7360 & -111.0075 & $0.2 \mathrm{ML}$ IE & 143.4 & 2.18 & 7 & 156 & 11.0 & 0.04 & 1.3 & 12.7 \\
\hline 11/10/2012 16:06:03 & 43.9037 & -113.7212 & 1.3 Mc IE & 80.6 & 2.47 & 15 & 197 & 21.8 & 0.09 & 0.8 & 1.2 \\
\hline 11/10/2012 19:00:20 & 44.4985 & -114.2157 & $2.4 \mathrm{Mc} \mathrm{IE}$ & 148.6 & 0.64 & 12 & 256 & 67.8 & 0.10 & 1.5 & 3.4 \\
\hline 11/11/2012 15:59:11 & 44.5205 & -114.3115 & $2.0 \mathrm{Mc} \mathrm{MB}$ & 156.0 & 1.28 & 14 & 118 & 75.9 & 0.09 & 0.7 & 1.9 \\
\hline 11/11/2012 16:35:18 & 44.4798 & -114.2782 & $0.9 \mathrm{Mc} \mathrm{IE}$ & 151.2 & 5.67 & 7 & 258 & 90.1 & 0.07 & 1.3 & 3.7 \\
\hline 11/12/2012 5:13:37 & 42.7550 & -111.2747 & 1.4 ML IE & 157.9 & 4.42 & 15 & 92 & 14.3 & 0.05 & 0.4 & 4.4 \\
\hline 11/12/2012 9:08:25 & 43.3490 & -110.8792 & $0.6 \mathrm{ML} \mathrm{IE}$ & 157.5 & 2.29 & 10 & 175 & 2.7 & 0.04 & 0.7 & 1.8 \\
\hline
\end{tabular}




\begin{tabular}{|c|c|c|c|c|c|c|c|c|c|c|c|}
\hline ORIGIN TIME & LAT N & LONG W & MAG-TYPE & DIST & Z & NO & GAP & DMIN & RMS & $\mathrm{ERH}$ & $\mathrm{ERZ}$ \\
\hline 11/13/2012 17:58:15 & 44.5732 & -113.9932 & 1.0 ML IE & 141.2 & 6.45 & 6 & 284 & 55.1 & 0.06 & 1.9 & 5.5 \\
\hline $11 / 13 / 2012$ 21:10:14 & 44.4213 & -113.0278 & $0.9 \mathrm{ML} \mathrm{IE}$ & 88.0 & 10.15 & 11 & 129 & 12.3 & 0.06 & 0.4 & 1.5 \\
\hline $11 / 14 / 2012$ 22:33:15 & 43.5038 & -111.1217 & $0.8 \mathrm{ML} \mathrm{IE}$ & 135.1 & 10.00 & 10 & 232 & 13.9 & 0.07 & 1.1 & 1.7 \\
\hline 11/15/2012 16:23:00 & 44.6928 & -112.4783 & $2.5 \mathrm{Mc} M B$ & 118.5 & 9.76 & 35 & 92 & 12.9 & 0.04 & 0.2 & 0.6 \\
\hline 11/15/2012 17:21:37 & 44.7233 & -112.4655 & $0.9 \mathrm{Mc}$ MB & 122.1 & 0.02 & 6 & 113 & 15.5 & 0.03 & 1.0 & 2.6 \\
\hline 11/16/2012 7:01:39 & 43.8913 & -110.9785 & 1.1 ML IE & 147.7 & 6.93 & 11 & 146 & 3.2 & 0.05 & 0.5 & 0.7 \\
\hline 11/17/2012 19:39:45 & 44.3643 & -111.0535 & $0.6 \mathrm{Mc} \mathrm{IE}$ & 159.8 & 3.47 & 5 & 235 & 21.9 & 0.05 & 2.1 & 11.0 \\
\hline 11/17/2012 20:55:48 & 43.2528 & -110.9442 & 1.2 ML IE & 155.2 & 0.03 & 11 & 160 & 14.3 & 0.09 & 0.9 & 2.0 \\
\hline 11/17/2012 22:03:55 & 42.7042 & -111.5720 & 1.2 Mc IE & 144.1 & 3.07 & 12 & 95 & 28.7 & 0.13 & 0.5 & 12.3 \\
\hline 11/19/2012 12:46:12 & 44.7077 & -112.4107 & 1.3 Mc MB & 121.4 & 2.87 & 9 & 180 & 12.8 & 0.06 & 0.8 & 0.7 \\
\hline 11/19/2012 22:52:49 & 44.2455 & -114.1160 & $2.4 \mathrm{Mc} \mathrm{M}$ & 125.8 & 3.33 & 22 & 218 & 57.2 & 0.04 & 0.5 & 2.3 \\
\hline 11/20/2012 20:41:04 & 42.9033 & -111.4652 & 1.5 ML IE & 135.4 & 6.17 & 12 & 170 & 5.2 & 0.04 & 1.1 & 0.7 \\
\hline $11 / 20 / 2012$ 20:41:28 & 42.8907 & -111.5188 & 1.8 ML IE & 132.9 & 7.25 & 8 & 274 & 9.5 & 0.04 & 1.4 & 1.1 \\
\hline 11/20/2012 21:08:18 & 42.8935 & -111.5348 & $2.0 \mathrm{ML} \mathrm{IE}$ & 131.7 & 6.16 & 9 & 275 & 10.5 & 0.05 & 1.4 & 1.3 \\
\hline $11 / 21 / 2012$ 0:58:27 & 42.8755 & -111.5698 & 1.2 ML IE & 130.8 & 4.46 & 7 & 292 & 14.0 & 0.05 & 1.6 & 4.3 \\
\hline 11/21/2012 15:48:49 & 44.7967 & -111.7640 & 1.3 ML IE & 151.3 & 10.69 & 7 & 220 & 10.8 & 0.01 & 1.8 & 1.7 \\
\hline 11/22/2012 0:19:59 & 42.8167 & -111.2872 & $0.8 \mathrm{ML} \mathrm{IE}$ & 152.8 & 9.30 & 5 & 211 & 16.3 & 0.02 & 2.0 & 4.6 \\
\hline $11 / 23 / 20120: 14: 21$ & 44.8557 & -112.1593 & $1.5 \mathrm{Mc} \mathrm{MB}$ & 143.1 & 0.93 & 12 & 140 & 34.6 & 0.05 & 0.6 & 1.6 \\
\hline 11/23/2012 3:48:16 & 42.5830 & -111.5878 & $0.7 \mathrm{ML}$ IE & 153.4 & 5.74 & 8 & 235 & 41.7 & 0.10 & 1.4 & 7.7 \\
\hline 11/23/2012 4:12:03 & 43.3763 & -110.9428 & $0.9 \mathrm{ML} \mathrm{IE}$ & 151.8 & 5.49 & 11 & 122 & 7.5 & 0.07 & 0.8 & 2.5 \\
\hline 11/23/2012 6:38:25 & 42.8717 & -111.1310 & $0.7 \mathrm{ML} \mathrm{IE}$ & 159.6 & 9.63 & 9 & 140 & 12.1 & 0.02 & 1.0 & 3.8 \\
\hline 11/23/2012 17:12:42 & 43.5100 & -111.0127 & $0.8 \mathrm{ML} \mathrm{IE}$ & 143.8 & 0.88 & 9 & 209 & 5.5 & 0.05 & 0.9 & 0.6 \\
\hline 11/23/2012 20:15:13 & 43.5060 & -111.0118 & $0.7 \mathrm{Mc} \mathrm{IE}$ & 143.9 & 2.68 & 9 & 216 & 5.3 & 0.06 & 0.9 & 3.9 \\
\hline 11/24/2012 4:19:37 & 44.5822 & -112.8503 & $0.4 \mathrm{ML} \mathrm{IE}$ & 103.9 & 2.26 & 4 & 165 & 27.3 & 0.00 & 2.8 & 3.3 \\
\hline 11/24/2012 15:37:56 & 43.5072 & -111.0125 & 2.1 ML IE & 143.8 & 1.56 & 34 & 139 & 5.3 & 0.04 & 0.3 & 0.4 \\
\hline 11/25/2012 3:02:43 & 43.1720 & -110.9322 & $0.6 \mathrm{ML} \mathrm{IE}$ & 159.0 & 10.64 & 8 & 222 & 22.1 & 0.11 & 1.5 & 3.2 \\
\hline 11/25/2012 3:19:12 & 43.1660 & -110.9247 & $0.5 \mathrm{ML} \mathrm{IE}$ & 159.8 & 3.51 & 8 & 225 & 22.6 & 0.04 & 1.3 & 9.5 \\
\hline 11/25/2012 7:02:25 & 43.5107 & -111.0120 & $0.5 \mathrm{ML} \mathrm{IE}$ & 143.8 & 1.03 & 8 & 209 & 5.5 & 0.04 & 1.0 & 0.7 \\
\hline 11/25/2012 17:17:36 & 43.5057 & -111.0173 & $0.6 \mathrm{ML} \mathrm{IE}$ & 143.5 & 2.53 & 9 & 212 & 5.7 & 0.07 & 0.9 & 5.1 \\
\hline 11/25/2012 17:44:54 & 43.3133 & -110.9050 & 1.1 ML IE & 156.4 & 5.45 & 10 & 157 & 6.9 & 0.07 & 0.6 & 1.4 \\
\hline 11/26/2012 10:33:49 & 43.5057 & -111.0183 & $0.8 \mathrm{Mc} \mathrm{IE}$ & 143.4 & 1.24 & 9 & 212 & 5.7 & 0.04 & 0.8 & 0.7 \\
\hline 11/27/2012 1:52:39 & 42.9238 & -111.4620 & $0.9 \mathrm{Mc} \mathrm{IE}$ & 134.2 & 0.01 & 6 & 267 & 3.7 & 0.13 & 2.1 & 0.9 \\
\hline 11/27/2012 15:26:50 & 44.0080 & -114.4372 & $1.9 \mathrm{ML}$ IE & 138.8 & 6.92 & 7 & 250 & 49.6 & 0.03 & 1.1 & 12.8 \\
\hline 11/27/2012 20:13:44 & 43.5183 & -110.9747 & $0.0 \mathrm{ML} \mathrm{IE}$ & 146.7 & 3.02 & 5 & 193 & 3.7 & 0.05 & 1.1 & 2.5 \\
\hline 11/29/2012 8:15:38 & 44.4458 & -113.9457 & 1.1 ML IE & 128.5 & 6.99 & 7 & 222 & 45.6 & 0.07 & 1.0 & 4.4 \\
\hline 11/29/2012 9:22:00 & 43.5110 & -111.0037 & $0.8 \mathrm{Mc} \mathrm{IE}$ & 144.5 & 1.59 & 9 & 210 & 4.9 & 0.06 & 1.3 & 0.9 \\
\hline 11/30/2012 5:03:52 & 43.3398 & -110.9555 & $0.9 \mathrm{ML}$ IE & 151.7 & 5.09 & 8 & 278 & 8.8 & 0.07 & 1.4 & 3.1 \\
\hline 11/30/2012 8:18:18 & 43.5153 & -111.0018 & $0.6 \mathrm{Mc} \mathrm{IE}$ & 144.6 & 1.19 & 9 & 208 & 5.0 & 0.05 & 0.9 & 0.7 \\
\hline $12 / 1 / 2012$ 21:32:43 & 43.8470 & -113.4525 & $0.9 \mathrm{ML} \mathrm{IE}$ & 58.2 & 3.55 & 9 & 112 & 9.1 & 0.05 & 0.5 & 0.8 \\
\hline $12 / 2 / 2012$ 12:41:35 & 43.3377 & -110.9350 & 1.0 ML IE & 153.4 & 2.28 & 7 & 281 & 7.3 & 0.09 & 1.5 & 11.1 \\
\hline $12 / 3 / 2012$ 18:35:47 & 44.6157 & -114.0477 & 1.3 Mc IE & 147.6 & 5.03 & 5 & 241 & 61.3 & 0.07 & 2.3 & 11.8 \\
\hline $12 / 4 / 2012$ 5:17:00 & 43.2598 & -111.4453 & 1.1 Mc IE & 116.6 & 3.92 & 9 & 206 & 23.7 & 0.07 & 1.1 & 9.8 \\
\hline 12/5/2012 18:10:16 & 44.3395 & -114.0318 & 1.5 ML IE & 126.1 & 6.34 & 12 & 219 & 50.1 & 0.10 & 1.0 & 4.2 \\
\hline 12/7/2012 8:03:50 & 43.2078 & -110.9038 & $0.9 \mathrm{ML} \mathrm{IE}$ & 159.8 & 0.03 & 7 & 218 & 17.7 & 0.07 & 1.8 & 2.5 \\
\hline 12/11/2012 8:22:48 & 44.1930 & -114.5097 & 1.5 ML IE & 151.2 & 7.14 & 7 & 268 & 70.5 & 0.06 & 1.3 & 6.6 \\
\hline $12 / 12 / 20126: 45: 15$ & 44.7177 & -111.7960 & 1.7 Mc MB & 142.6 & 5.07 & 12 & 180 & 76.3 & 0.05 & 0.5 & 2.6 \\
\hline 12/13/2012 2:31:02 & 43.9560 & -114.2582 & 1.4 Mc IE & 123.4 & 2.06 & 10 & 284 & 64.8 & 0.07 & 1.7 & 4.1 \\
\hline 12/15/2012 15:23:53 & 43.1292 & -110.9445 & $0.5 \mathrm{ML} \mathrm{IE}$ & 159.8 & 5.80 & 11 & 171 & 27.0 & 0.03 & 0.7 & 5.4 \\
\hline 12/17/2012 13:51:52 & 43.8260 & -110.9838 & $0.5 \mathrm{ML}$ IE & 146.2 & 2.50 & 7 & 149 & 21.2 & 0.05 & 0.7 & 12.3 \\
\hline
\end{tabular}




\begin{tabular}{|c|c|c|c|c|c|c|c|c|c|c|c|}
\hline ORIGIN TIME & LAT N & LONG W & MAG-TYPE & DIST & $Z$ & NO & GAP & DMIN & RMS & $\mathrm{ERH}$ & $\mathrm{ERZ}$ \\
\hline 12/17/2012 22:21:01 & 44.2510 & -114.0993 & $2.1 \mathrm{Mc} M B$ & 125.0 & 0.85 & 19 & 218 & 55.8 & 0.06 & 0.6 & 1.4 \\
\hline 12/18/2012 22:23:01 & 43.7080 & -111.0623 & 1.0 Mc IE & 138.8 & 2.32 & 8 & 191 & 8.3 & 0.05 & 0.8 & 11.0 \\
\hline $12 / 22 / 2012$ 7:24:53 & 43.7388 & -111.0822 & $0.4 \mathrm{Mc} \mathrm{IE}$ & 137.4 & 2.45 & 8 & 235 & 12.0 & 0.10 & 2.8 & 10.8 \\
\hline 12/24/2012 10:13:31 & 44.7433 & -111.7835 & $1.5 \mathrm{Mc} \mathrm{MB}$ & 145.5 & 3.53 & 8 & 141 & 9.5 & 0.02 & 0.8 & 1.4 \\
\hline 12/24/2012 23:39:12 & 43.2138 & -110.8997 & $0.6 \mathrm{ML}$ IE & 160.0 & 5.68 & 7 & 171 & 16.9 & 0.09 & 1.4 & 4.5 \\
\hline 12/26/2012 5:53:07 & 44.6033 & -112.7468 & 1.2 Mc MB & 106.1 & 2.56 & 11 & 104 & 26.2 & 0.04 & 0.4 & 1.0 \\
\hline 12/26/2012 7:20:47 & 44.6973 & -112.5365 & 1.8 Mc MB & 118.2 & 13.95 & 10 & 89 & 16.2 & 0.06 & 0.5 & 1.3 \\
\hline 12/29/2012 6:19:15 & 43.7998 & -110.8310 & $1.4 \mathrm{ML} \mathrm{IE}$ & 158.1 & 6.70 & 11 & 120 & 23.9 & 0.02 & 0.5 & 4.1 \\
\hline 12/30/2012 19:12:53 & 43.4585 & -110.9030 & $0.1 \mathrm{Mc}$ IE & 153.3 & 8.61 & 7 & 155 & 5.2 & 0.04 & 0.6 & 1.8 \\
\hline 12/31/2012 21:52:05 & 43.2540 & -111.3548 & $0.8 \mathrm{ML}$ IE & 123.7 & 4.96 & 8 & 209 & 42.0 & 0.04 & 0.9 & 11.9 \\
\hline
\end{tabular}

